UNIVERSIDADE DE SÃO PAULO

FACULDADE DE EDUCAÇÃO

JÚLIO CÉSAR BEZERRA

"O que estamos fazendo?"

Reflexos da racionalidade legalista sobre a atividade dos atores educacionais

São Paulo

2013 


$$
\text { JÚLIO CÉSAR BEZERRA }
$$

\section{"O que estamos fazendo?" \\ Reflexos da racionalidade legalista sobre \\ a atividade dos atores educacionais}

Versão original

Dissertação apresentada à Faculdade de Educação da Universidade de São Paulo para obtenção do título de Mestre em Educação

Área de Concentração: Sociologia da Educação

Orientadora: Prof $^{a} . \quad \mathrm{Dr}^{\mathrm{a}}$. Kimi Aparecida Tomizaki

São Paulo 
Autorizo a reprodução e divulgação total ou parcial deste trabalho, por qualquer meio convencional ou eletrônico, para fins de estudo e pesquisa, desde que citada a fonte.

Catalogação na Publicação

Serviço de Biblioteca e Documentação

Faculdade de Educação da Universidade de São Paulo

379.33(81.61) Bezerra, Júlio César

B574q "O que estamos fazendo?”: reflexos da racionalidade legalista sobre a atividade dos atores educacionais / Júlio César Bezerra ; orientação Kimi Aparecida Tomizaki. São Paulo : s.n., 2013.

127 p. : il, grafs .tabs.

Dissertação (Mestrado - Programa de Pós-Graduação em Educação. Área de Concentração : Sociologia da Educação) - Faculdade de Educação da Universidade de São Paulo)

1. Escola pública - Regulamentação - São Paulo 2. Cotidiano escolar 3. Legislação escolar 4. Estado 5. Professores I. Tomizaki, Kimi Aparecida, orient. 
BEZERRA, Júlio César

"O que estamos fazendo?" Reflexos da racionalidade legalista sobre a atividade dos atores educacionais

Dissertação apresentada à

Faculdade de Educação da

Universidade de São Paulo para

obtenção do título de Mestre em

Educação

Área de Concentração: Sociologia da Educação

Aprovado em:

Banca Examinadora

Prof. Dr. Instituição:

Julgamento:

Assinatura:

Prof. Dr. Instituição:

Julgamento:

Assinatura:

Prof. Dr. Instituição:

Julgamento: Assinatura: 


\section{AGRADECIMENTOS}

Para escrever esta dissertação, foi essencial o incentivo da Fundação de Amparo à Pesquisa do Estado de São Paulo (FAPESP) e indispensável a colaboração de algumas pessoas, a quem manifesto aqui minha profunda gratidão.

Os estudos e investigações que tornaram possível a elaboração deste texto foram apoiados e custeados por bolsa da FAPESP.

Assim, registro o meu agradecimento à FAPESP pelo apoio e financiamento concedidos para a realização desta pesquisa - fomento sem o qual a concretização deste trabalho teria sido seriamente obstada.

À professora Kimi Tomizaki, minha orientadora, que acolheu desde o início as ideias e o projeto com empenho e interesse.

Devo uma especial expressão de gratidão à professora Flávia Schilling pela leitura abrangente e atenta do texto no Exame de Qualificação, o que permitiu, por meio de seus apontamentos, suas reflexões, questões, e graças à sua exigência, uma tarefa de reformulação teórica, exercendo um papel decisivo na concepção final do trabalho.

Contraí, igualmente, uma dívida especial para com a professora Fabiana Jardim por sua leitura detalhada da versão inicial do texto na ocasião da Qualificação, por sua crítica equilibrada e por seus conselhos os mais valiosos.

Pelos benefícios que me foram proporcionados a partir desses contatos, por terem chamado minha atenção para aspectos e contornos pesquisados, espero que ambas possam encontrar nas páginas seguintes evidências marginais de suas ideias e grande inspiração.

Agradeço a todos os anônimos que fizeram parte desta pesquisa, os quais, por motivos éticos, não serão identificados, mas, graças a suas intervenções, atitudes e falas, contribuíram para o desenvolvimento e o enriquecimento do estudo. Aos docentes, coordenadores, funcionários e às diretoras das escolas estaduais observadas, pela autorização e preciosa assistência oferecida para o acompanhamento das atividades e coleta de informações, o meu muito obrigado. 
O segredo da existência humana não consiste somente em viver, mas também em saber para que se vive.

Fiódor Dostoiévski

A necessidade da razão não é inspirada pela busca da verdade, mas pela busca do significado. $E$ verdade e significado não são a mesma coisa. [...] $\mathrm{O}$ pensamento tem sem dúvida um papel muito grande em toda busca científica; mas é o papel de um meio em relação a um fim; o fim é determinado por uma decisão a respeito do que vale a pena conhecer, e essa decisão não pode ser científica.

Hannah Arendt

O homem, considerado na sua essência e nas suas relações, é o enigma de mais difícil explicação.

Santo Agostinho

O trabalho dobra e redobra o tempo, e cem anos de servir são quatrocentos anos de padecer.

Padre Antônio Vieira

A vida não é indiferente às condições nas quais ela é possível, a vida é polaridade e, por isso mesmo, posição inconsciente de valor, em resumo, a vida é, com efeito, uma atividade normativa.

Georges Canguilhem 


\section{RESUMO}

BEZERRA, Júlio César. “O que estamos fazendo?” Reflexos da racionalidade legalista sobre a atividade dos atores educacionais. 2013. 127 f. Dissertação (Mestrado) - Faculdade de Educação, Universidade de São Paulo, São Paulo, 2013.

A presente pesquisa tem por objetivo central investigar os efeitos de atos oficiais sobre as práticas e os comportamentos dos indivíduos implicados no processo educacional nas instituições de ensino do Estado de São Paulo. Ela tem a pretensão de se inserir numa discussão sobre o desenvolvimento prolongado do processo calculado de regulamentação e suas exigências no cenário público. Nesta pesquisa entendemos que os atos oficiais são formações discursivas concebidas como estratégias de poder que incidem sobre a ordenação dos afazeres e dos dizeres dos atores. Por esta razão, o cerne da discussão proposta está em compreender as maneiras como os sujeitos lidam com esse arsenal de regras legais que está à disposição e como reagem a isso, atentando para os efeitos no cotidiano. Trata-se da tentativa de articular uma dimensão estrutural com as formas, as atitudes, as posições assumidas pelas subjetividades. Interessa, sobretudo, pensar nas estratégias - no caso, estratégia estatal e dos atores - e como as condutas se conduzem. A partir de uma abordagem sobre a ordenação racional e deliberada do poder público e sobre sua atuação na padronização da estrutura de funcionamento das escolas, utilizando documentos que possuem como objetivo precípuo o estabelecimento de regras e a criação de procedimentos, a primeira etapa da pesquisa esteve concentrada na análise documental, na qual foram contemplados textos legais, publicados no Diário Oficial do Estado de São Paulo entre 2007 e 2008, sob a forma de portarias, resoluções, leis e decretos, buscando e selecionando aqueles dispositivos conexos ou afins que abordam o campo educacional. Na segunda etapa desenvolvemos pesquisa empírica por meio da observação direta das práticas escolares de docentes e gestores, explorando as relações entre os aspectos legais e suas (des)conexões com o cotidiano das instituições de ensino público, a partir de dois contextos escolares localizados na Grande São Paulo. A abordagem aqui mobilizada nos coloca diante das possibilidades e limitações humanas num contexto de atos oficiais e discursos institucionalizados. Na linha de investigação aberta, procuramos estabelecer o que aqueles dispositivos e a racionalidade que os acompanha produzem e induzem a produzir nas subjetividades. $\mathrm{O}$ trabalho de se aproximar da dimensão legalista, por toda uma atividade de caráter contínuo e permanente, revelou mecanismos que compõem uma estratégia estatal de "governamentalização" por excelência, estabelecendo o rigor dos procedimentos "normais" da instituição. A partir das situações observadas nas escolas, a relação instalada com o arsenal regulamentar evidenciou que os atores conseguem articular, em meio ao emaranhado de mecanismos institucionais, ações, posições e decisões na trama regulamentar. No jogo de disputas entre a racionalidade legalista e a soberania de si próprio, eles realinham suas estratégias e mobilizam os aspectos disponíveis para alcançar formas proveitosas de gerir os assuntos escolares. A experiência escolar revelou tensões, articulações e vínculos com legalidades e ilegalidades - dinâmicas nas quais regulamentos e procedimentos são utilizados e manipulados de acordo com as perspectivas, intenções e decisões dos atores, em um jogo de lutas e de embates entre estratégias estatais e práticas cotidianas estratégicas.

Palavras-chave: Escola pública. Estado. Regulamentação. Cotidiano escolar. Docentes. Legislação escolar. 


\begin{abstract}
BEZERRA, Júlio César. "What are we doing?" Reflections of legalistic rationality of the actors on the educational activity. 2013. $127 \mathrm{f}$. Dissertation (Master) - Faculty of Education, University of São Paulo, São Paulo, 2013.
\end{abstract}

This research aims to investigate the effects of central official acts on the practices and behaviors of individuals involved in the educational process in educational institutions of the State of São Paulo. She pretends to be incorporated into a prolonged discussion of the development process and their calculated regulatory requirements on the public stage. In this research we believe that official acts are conceived as discursive power strategies that focus on the ordering of affairs and the sayings of the actors. For this reason, the core of the discussion proposal is to understand the ways in which individuals deal with this arsenal of legal rules that are available and how they react to it, paying attention to the effects on daily life. It is the attempt to articulate a structural dimension with the shapes, attitudes, positions taken by the subjects. Interested, mainly, thinking strategies - in this case, government strategy and actors - and how the pipes are lead. From a rational approach to ordering and deliberate on the government and its work in standardizing the structure and functioning of schools, using documents that have as main objective the establishment of rules and the creation of procedures, the first step of the research was concentrated in document analysis, which were contemplated legal texts published in the Official Gazette of the State of São Paulo between 2007 and 2008, in the form of ordinances, resolutions, laws and decrees, searching and selecting those related devices or similar addressing the educational field. In the second stage we develop empirical research through direct observation of the practices of teachers and school managers, exploring the relationship between legal aspects and their (dis) connections with everyday institutions of public education, from two contexts school located in the Great São Paulo. The approach here mobilized confronts us the possibilities and human limitations in the context of official acts and speeches institutionalized. At the open investigation, we sought to establish what those devices and rationality that accompanies produce and produce induces in subjectivities. The job of approaching the legalistic dimension, throughout an activity of continuous and permanent character, revealed mechanisms forming a government strategy to "governmentalisation" par excellence, establishing the rigor of the "normal" procedures of the institution. From the observed situations in schools, the relationship with the installed arsenal regulatory showed that actors can articulate, amid the tangle of institutional mechanisms, actions, positions and regulatory decisions in the plot. In the game of legalistic disputes between rationality and sovereignty of yourself, they realign their strategies and mobilize aspects available to achieve profitable ways to manage school affairs. The school experience revealed tensions, joints and connections with legalities and illegalities - dynamic in which regulations and procedures are used and handled according to the perspectives, intentions and decisions of the players, in a game of fighting and clashes between state strategies and daily practices strategic.

Keywords: Public school. State. Regulation. Daily school. Teachers. Law school. 


\section{LISTA DE GRÁFICOS}

Gráfico 1 - Publicação de atos regulamentares segundo os dias da semana - ano 2007

Gráfico 2 - Publicação de atos regulamentares segundo os dias da semana - ano 2008

Gráfico 3 - Portarias de admissões e dispensas (movimentação de pessoal) - ano 2007

Gráfico 4 - Portarias de admissões e dispensas (movimentação de pessoal) - ano 2008

Gráfico 5 - Publicação de Portarias a respeito da situação funcional dos servidores - ano 2007 26

Gráfico 6 - Publicação de Portarias a respeito da situação funcional dos servidores - ano 2008

Gráfico 7 - Publicação de atos regulamentares - São Paulo, 2007 e 2008 29

Gráfico 8 - Publicação de Decretos no ano de 2007 30

Gráfico 9 - Publicação de Decretos no ano de 2008. 30

Gráfico 10 - Publicação de Leis no ano de 2007. 31

Gráfico 11 - Publicação de Leis no ano de 2008. 31

Gráfico 12 - Publicação de Portarias no ano de 2007 32

Gráfico 13 - Publicação de Portarias no ano de 2008 32

Gráfico 14 - Publicação de Resoluções no ano de 2007. 33

Gráfico 15 - Publicação de Resoluções no ano de 2008. 33

Gráfico 16 - Volume de páginas publicadas no ano de 2007 - Seção I... 34

Gráfico 17 - Volume de páginas publicadas no ano de 2008 - Seção I 34

Gráfico 18 - Volume de páginas publicadas no ano de 2007 - Seção II. 35

Gráfico 19 - Volume de páginas publicadas no ano de 2008 - Seção II. 35 


\section{LISTA DE TABELAS}

Tabela 1 - Publicações de atos regulamentares

em 244 edições do Diário Oficial - ano 2007

Tabela 2 - Publicações de atos regulamentares

em 246 edições do Diário Oficial - ano 2008...................................... 22

Tabela 3 - Outros atos publicados

(âmbitos educacional e geral) - ano 2007........................................... 27

Tabela 4 - Outros atos publicados

(âmbitos educacional e geral) - ano 2008 


\section{LISTA DE SIGLAS}

CEE Conselho Estadual de Educação

CEFAM Centro Específico de Formação e Aperfeiçoamento do Magistério

CEI Coordenadoria de Ensino do Interior

CENP Coordenadoria de Estudos e Normas Pedagógicas

CGEB Coordenadoria de Gestão da Educação Básica

CGRH Coordenadoria de Gestão de Recursos Humanos

CIMA Coordenadoria de Informação, Monitoramento e Avaliação Educacional

CISE Coordenadoria de Infraestrutura e Serviços Escolares

COFI Coordenadoria de Orçamento e Finanças

COGSP Coordenadoria de Ensino da Região Metropolitana da Grande São Paulo

CPE Comitê de Políticas Educacionais

CRE Centro de Referência em Educação

DRHU Departamento de Recursos Humanos

DSE Departamento de Suprimento Escolar

EFAP Escola de Formação e Aperfeiçoamento de Professores

FDE Fundação para o Desenvolvimento da Educação

HTPC Horas de Trabalho Pedagógico Coletivo

IDESP Índice de Desenvolvimento da Educação do Estado de São Paulo

IPRS Índice Paulista de Responsabilidade Social

IPVS Índice Paulista de Vulnerabilidade Social

LDB Lei de Diretrizes e Bases da Educação Nacional

SARESP Sistema de Avaliação do Rendimento Escolar do Estado de São Paulo

SE Secretaria da Educação

SEADE Fundação Sistema Estadual de Análise de Dados

SEE Secretaria de Estado da Educação

SF $\quad$ Secretaria da Fazenda

SGP Secretaria de Gestão Pública

UCRH Unidade Central de Recursos Humanos 


\section{SUMÁRIO}

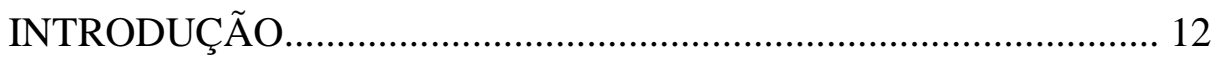

CAPÍTULO 1

A REGULAMENTAÇÃO ESTATAL .............................................. 21

1.1 Dimensões e aspectos na publicação regulamentar........................ 21

1.2 A legalização como estratégia estatal.......................................... 46

CAPÍTULO 2 REGRAS E PRÁTICA COTIDIANA:

RELATO SOBRE AS ATIVIDADES E

EXPERIÊNCIAS NO CONTEXTO ESCOLAR............................... 54

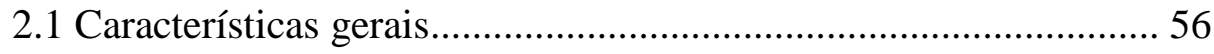

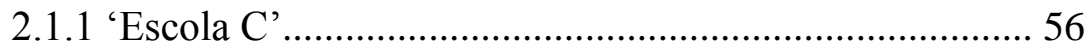

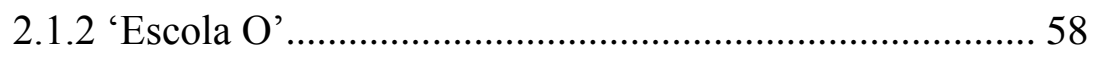

2.2 Acompanhando práticas cotidianas - as HTPC .............................. 61

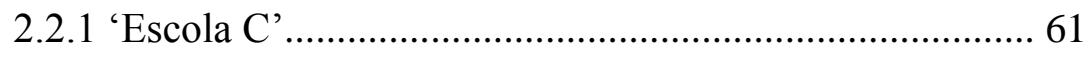

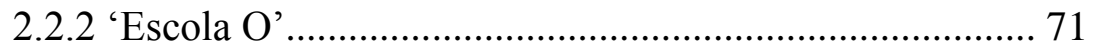

2.3 Acompanhando práticas cotidianas - o Conselho de Classe.......... 76

2.4 Da escuta à compreensão: relatando uma entrevista...................... 84

CAPÍTULO 3 BUROCRACIA, ESTADO E ESCOLA: REFLEXÕES.................... 97

3.1 Previsão, planejamento, ordem e gestão...................................... 98

3.2 Experiência, prática e posicionamento....................................... 109

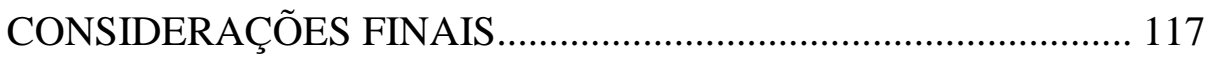

REFERÊNCIAS BIBLIOGRÁFICAS........................................... 122 


\section{INTRODUÇÃO}

A ação modulada e receitada, a racionalidade instrumentalizada, a técnica como o coroamento da prática, um contexto de decisões apriorísticas e de modelos disponíveis características da sociedade contemporânea - encontram-se, no sistema educacional público, com uma dimensão legislativa dotada de legitimidade, instrumentação e metódico ordenamento prático, notadamente no que concerne à função dos atores envolvidos, sejam eles educadores ou administradores. Absorvidos por um turbilhão de questões de ordem burocrática - materializada na forma opaca de decretos, leis, resoluções, portarias, comunicados e demais informações de cunho prescritivo -, o "fazer" e o cumprimento das obrigações da função pública parecem os ocupar sobremaneira, num cenário, por vezes, de uma "trivialidade sem sentido" (ARENDT, 1987, p. 8), um ambiente de execução de tarefas constantes, diárias, repetitivas e de ações dominadas pelo motivo pragmático.

Típico das sociedades ocidentais modernas, o processo de racionalização crescente trouxe consigo formas e fórmulas que impõem sacrifícios enormes à ação, na medida em que submete todos os atos e todas as decisões ao ritmo da racionalidade instrumental, do cálculo e da burocratização. ${ }^{1}$ Tais condições e as subsequentes transformações no tecido social formaram o substrato a partir do qual o arcabouço teórico se apoiou e se desenvolveu, fomentando exames e análises entre pensadores - notadamente Max Weber (1979) e sua discussão sobre a dominação racional-legal como a face do quadro burocrático - sobre as questões e os efeitos relacionados à organização prioritária das atividades por meio de estruturas burocráticas.

Ao discutir a organização inerente àquelas estruturas, Motta (1988) demonstra que a formalização, os procedimentos por escrito, as exigências de disciplina e conformismo alimentadas pelo dever, pela limitada autoridade e pela metódica rotinização das atividades -, são características do excesso de burocratização das instituições. Os formalismos se transformam rapidamente em ritualismos; assim, o funcionário seria o "sacerdote" que aplicaria regras sem discutir, independente dos fatores ou condições momentâneas, guiado por princípios rígidos e documentais, ou seja, a materialização compulsória por meio dos papéis. Numa mesma vertente e em sentido complementar, Tragtenberg (1977, p. 159) revela que:

\footnotetext{
${ }^{1}$ Para uma discussão sobre o processo de burocratização, v. NUNES, Edson. A gramática política do Brasil. Clientelismo e insulamento burocrático. Rio de Janeiro: Jorge Zahar, 1997.
} 
[...] a burocracia, 'em nome da organização', usa e abusa das imunidades e privilégios inerentes a ela enquanto poder acima dos organizados. Por isso, ela tem como religião o culto da hierarquia, ou seja, o culto da distribuição desigual do poder, onde poucos podem muito e muitos não têm voz.

Em seus múltiplos aspectos, a dinâmica inerente às estruturas institucionais indicaria um "pensamento" e uma ação baseados no raciocínio prático, por meio do qual o indivíduo utilizaria os modelos disponíveis (protocolos, normas e convenções oficiais e oficiosas) para estabelecer a linha de ação. ${ }^{2}$

Nada disso é novo na estrutura da vida contemporânea, como também sustenta Hannah Arendt (1987). O sistema de ensino, nessa conjuntura, foi progressivamente sendo burocratizado - submetido às regras e com profissionais habilitados formalmente para exercer as atribuições dos respectivos cargos. Essa crescente preponderância ordenativa foi acompanhada de relevantes abordagens teóricas na interpretação do sistema de ensino: por um lado, concebendo a escola e seus atores como instâncias capazes de proporcionar a formação e transformação de sujeitos e de suas ações (CAÇÃO, 1989; MINGUILI, 1995; MOREIRA, 2001; PEREIRA, 2008; SANTIAGO, 2005; SANTOS, 2001; VEIGA-NETO, 2003; VILELA, 2007); por outro lado, apontando para o caráter cerceador da burocracia escolar e para as barreiras que se interpõem à atuação dos atores (ARROYO, 1991; FELIX, 1982; FORTUNATO, 1998; GÓMEZ, 1996; GRACELLI, 1986; MERTON, 1971; MONLEVADE; SILVA, 2000; MOTTA, 1988). Tal panorama ajuda a compor diferentes aspectos dos cenários escolares nos quais se estabelecem as ações e reações dos atores envolvidos.

É típico da Sociologia buscar compreender a ação humana. Nessa busca, Max Weber (2001) demonstrou, em uma de suas obras de referência, que o espírito capitalista, como dedicação para a conquista da rentabilidade, é resultado e expressão de virtude e eficiência no exercício da profissão. É mais que um dever no sistema capitalista - supõe um dever moral. São sempre os negócios comandando as pessoas, e não o contrário. A ascese do trabalho inunda as instituições e, em sentido oposto, a não imersão na profissão adquire um caráter de sacrilégio. Há um estrito relacionamento com o trabalho, sendo este a forma ascética por excelência.

Também com Weber aprendemos que a forma de rezar pelo trabalho constante foi a principal alavanca do desenvolvimento daquele espírito capitalista. Em todo o seu

\footnotetext{
${ }^{2}$ Para este aspecto, v. DOUGLAS, Mary. Como as Instituições Pensam. São Paulo: Edusp, 2007. Nesta obra, a autora esclarece até que ponto o "pensamento institucional" depende da forma como as instituições estão organizadas.
} 
espraiamento pela rede social, as ações perderam a finalidade com relação valorativa e ganharam a finalidade de fins. A profissionalização, em todas as áreas e instituições, há muito deixou de ser apenas um desejo para se tornar uma obrigação, uma atividade cujo fim é ela mesma. Segue-se daí que a racionalidade encarnada na burocracia estatal surge como resultado e uma das maiores expressões daquele "desencantamento do mundo", o qual "aumenta a eficiência e produtividade, mas, ao mesmo tempo, carrega a possibilidade da perda da liberdade e do sentido da vida" (SELL, 2012, p. 105).

Essas noções ganham maior envergadura quando as atrelamos à execução programada e ao desenvolvimento prolongado do processo calculado de regulamentação no quadro legislativo. Ao tratarmos de legislações, estamos abordando conteúdos que atingem as maneiras de conduzir a administração do cotidiano escolar. Formadas por ciclos anuais na área de educação, acionam e desencadeiam ações, tornadas rotineiras e tradicionais por sua preponderância organizacional, numa “[...] era de transformação, de dispersão e de inflação normativa que é a nossa" (EWALD, 2000, p. 65).

Os elementos acima apontam para uma herança imperativa, ou, em termos mais precisos, para um feixe de injunções, em relação ao qual "o diagnóstico weberiano da modernidade, expresso através da tese da perda de sentido e da perda de liberdade, confere uma tonalidade pessimista, mas, ao mesmo tempo, profundamente crítica da modernidade ocidental" (SELL, 2012, p. 131). Para nós, é fundamental também, nesse sentido, a perspectiva encontrada em Hannah Arendt (1999) ao analisar o julgamento de Adolf Eichmann, a partir do qual é possível tomar contato com os desdobramentos da noção de cumprimento do dever profissional.

A partir dessas considerações prévias, esta pesquisa e as reflexões a seguir têm por objetivo central investigar os efeitos de atos oficiais sobre as práticas e os comportamentos dos indivíduos implicados no processo educacional nas instituições de ensino do Estado de São Paulo. Ela tem a pretensão de se inserir numa discussão sobre um lugar público que parece se encontrar cerceado pela necessidade de responder de modo rápido e eficaz às exigências criadas por uma regulamentação específica. Há alguma prática em uso nas escolas que escapa aos verbos no modo imperativo, tão característicos do arcabouço legal?

Nesta pesquisa entendemos que os atos oficiais são formações discursivas concebidas como estratégias de poder que incidem sobre a ordenação dos afazeres e dos dizeres dos atores. Por essa razão, o cerne da discussão proposta está em compreender as maneiras como 
os sujeitos - mais especificamente, docentes e gestores ${ }^{3}$ - lidam com esse arsenal de regras legais que está à disposição e como reagem a isso, atentando para os efeitos no cotidiano. Trata-se da tentativa de articular uma dimensão estrutural com as formas, as atitudes, as posições assumidas pelas subjetividades; a tentativa de reparar no encontro entre esses dois polos de estratégias. Interessa, sobretudo, pensar nas estratégias - no caso, estratégia estatal e dos atores - e como as condutas se conduzem.

Nos termos em que sustentamos a presente discussão, não é de todo dispensável apontar que o desejo de poupar ao indivíduo qualquer constrangimento regulamentar constitui noção impotente e pouco merecedora de crédito. Por mais que o conjunto de regras e leis no ensino possa parecer uma área secundária ou um objeto de pesquisa marginal, não é possível tentar desqualificá-lo, de maneira grosseira ou refinada, sem incorrer em alguma leviandade teórica. Quanto mais nos aproximamos desse território, maior esforço se mostra necessário para aumentar o conhecimento acerca de seus aspectos e de seus efeitos cotidianos.

Por tais razões, e procurando seguir essa trama composta de fios entrelaçados, podemos propor alguns questionamentos. ${ }^{4}$ De que maneira a regulamentação é tratada no cotidiano escolar? Em algum momento elas são depuradas, discutidas, debatidas? Quais são os seus reflexos sobre a atuação dos indivíduos? Estes atores estão simplesmente dando voltas na ciranda legislativa? Nessa trama, não se trata de analisar políticas educacionais e constatar ou não sua implementação, eficácia ou fracasso; trata-se de voltar o olhar para os atores diretamente envolvidos e investigar as possibilidades daqueles mecanismos regulamentares serem subjugados, deslocados ou desdobrados. Aí reside o especial interesse sociológico pelos estabelecimentos de ensino.

Não é o caso de esquecer por isto 'o peso' das instituições, sua viscosidade, que se deve ao caráter objetivado de seus quadros e de suas decisões, produtos de relações passadas que perduram: a cristalização, no mundo material e nas formas institucionais, das relações sociais (BEAUD; WEBER, 2007, p. 212).

Se, de fato, as relações sociais nas instituições adquirem o caráter de relações institucionalizadas, qual seria a natureza da interação entre os indivíduos e as instituições, levando em conta suas características, formas, o contexto e o "peso", sua existência própria?

\footnotetext{
${ }^{3}$ Os gestores aos quais aqui nos referimos são os atores encarregados da administração cotidiana nas próprias unidades escolares e compreendem os diretores, vice-diretores e coordenadores pedagógicos.

${ }^{4}$ Não existe uma pergunta que possibilite uma conclusão geral. A existência de mais de uma pergunta torna possível abordar o problema de maneira multidimensional e obter perspectivas em um contexto.
} 
Qual seria, portanto, o espaço para manifestações e reinterpretações pelos indivíduos que a compõem $?^{5}$

Nossa teoria, enquanto hipótese a ser testada, é a de que a ação educativa estaria fortemente baseada nos regulamentos, visto que os atores implicados no sistema de ensino se encontram mergulhados numa estrutura que exige, a todo o momento, cumprimento de regras e sobrevaloriza a autoridade. ${ }^{6}$ Não devemos, evidentemente, nos deter nessa hipótese, mas considerar a possibilidade de microdecisões cotidianas e as tomadas de posição. Juntamente com as questões precedentes, essas noções formam o núcleo de inquietação e incômodo que nos motiva.

Supondo-se que todos esses questionamentos sejam inseparáveis, levando em consideração os elementos insistentes e os traços que sugerem para a investigação da problemática, estruturamos esta pesquisa em duas etapas.

Optamos por abordar a estrutura administrativa da escola, correspondendo a uma análise sobre a ordenação racional e deliberada do poder público e sobre sua atuação na padronização da estrutura de funcionamento das escolas. Dessa forma, a primeira etapa esteve concentrada na análise documental, na qual foram contemplados textos legais, publicados entre 2007 e 2008, sob a forma de portarias (documento de competência comum às autoridades administrativas, como dirigentes de entidades descentralizadas e órgãos colegiados), resoluções (de competência privativa do secretário estadual de educação), leis (de iniciativa dos legisladores ou do governador do Estado) e decretos (textos legais de competência privativa do governador do Estado), buscando - na esparsa e complexa legislação - e selecionando - tendo em vista a diversidade de assuntos tratados - aqueles dispositivos conexos ou afins, que abordam o campo educacional. Esse campo é constituído por documentos prescritivos, publicados no Diário Oficial do Estado de São Paulo, textos que possuem como objetivo precípuo o estabelecimento de regras e criação de procedimentos, visando estabelecer as armaduras para o aumento da eficiência e da produtividade na administração pública. Com a realização desse levantamento, apresentamos o panorama de regulamentação estatal nos anos pesquisados, em particular sobre o sistema escolar.

\footnotetext{
${ }^{5}$ Em face de vidas gestionadas, Arendt aponta para a possibilidade de o mundo estar se "desrealizando", resgatando o fato de que o triunfo de Adolf Hitler foi o resultado de uma boa gestão. A gestão realiza unicamente a política de resultados. Cf. ARENDT, H. Eichmann em Jerusalém. São Paulo: Companhia das Letras, 1999. Em Adorno, a alienação aumenta o potencial de adesão sem consciência. Cf. ADORNO, Theodor W. "Educação após Auschwitz". In: Cohn, Gabriel (org.). Theodor W. Adorno. Coleção Grandes Cientistas Sociais. São Paulo: Ática, 1986.

${ }^{6}$ Ao se debruçar sobre as instituições, Goffman (2005, p. 148) afirma que "não podemos pensar claramente nas exigências de compromisso e adesão que uma entidade social impõe a seus participantes sem pensar nos limites considerados adequados para tais exigências".
} 
Na segunda etapa desenvolvemos pesquisa empírica por meio da observação direta das práticas escolares de docentes e gestores durante reuniões das Horas de Trabalho Pedagógico Coletivo (HTPC) e do Conselho de Classe, explorando as relações entre os aspectos legais e suas (des)conexões com o cotidiano - como o lugar da ação - das instituições de ensino público, a partir de dois contextos escolares localizados na Grande São Paulo. Aqui, observar e descrever as representações dos atores do campo consiste em mais do que registrar o que eles dizem ou fazem, mas compreender suas palavras e suas práticas sociais também por meio de suas ausências: por exemplo, por meio da compreensão de por que jamais falam sobre o que fazem ou por que não falam ou não agem sobre os aspectos do trabalho que fazem. Para tanto, pretende-se não apenas reproduzir, mas reconstruir o real, transubstanciando a capacidade de observar em capacidade etnográfica para observar. Nesta tarefa, observar implica conviver e experienciar com os atores os diferentes espaços e ambientes escolares: "lugares e objetos são, a um só tempo, o contexto e o produto de interações sociais. Têm produtores e usuários. Trazem a marca dos eventos que ali se desenrolaram e esses eventos, reciprocamente, lhes devem algo" (BEAUD; WEBER, 2007, p. 112). Convém salientar que nosso objeto de interesse não residiu na sala de aula e não se limitou ao trabalho dos professores, mas à atuação dos atores escolares que compõem a instituição escolar, e nas lutas, apropriações e tensões que se estabelecem em torno dos instrumentos administrativos legais.

As afinidades apontadas - com suas limitações, mas, por certo, passíveis de alguma precisão - pareceram-nos merecedoras de uma importante interrogação. Em A Condição Humana, Hannah Arendt propõe como tema abordar "o que estamos fazendo", querendo assim discutir o fundamento da existência humana ou suas manifestações quintessenciais. Nesta oportunidade, tomamos para nós o tema em forma de questionamento, a pergunta que nos impele na abordagem da escola: o que estamos fazendo? -, nos incluindo nesta humanidade para a qual a era moderna trouxe a glorificação da técnica, da racionalidade burocrática e instrumental. A abordagem que procuramos levar adiante nos coloca diante das possibilidades e limitações humanas num contexto de atos oficiais e discursos institucionalizados,

como se o nosso cérebro, condição material e física do pensamento, não pudesse acompanhar o que fazemos, de modo que [...] necessitaríamos realmente de máquinas que pensassem e falassem por nós. Se realmente for comprovado esse divórcio definitivo entre o conhecimento [...] e o pensamento, então passaremos, sem dúvida, à condição de escravos 
indefesos, [...] criaturas desprovidas de raciocínio, à mercê de qualquer engenhoca tecnicamente possível, por mais mortífera que seja (ARENDT, 2008a, p. 11).

De toda forma, o objetivo da presente investigação é, de fato, mostrar de que modo se articulam dispositivos - regulamentares, antes de tudo - às ações, práticas e atitudes, e considerar as consequências da mera administração ou do uso da razão instrumentalizada no âmbito da educação pública. Nessa linha de investigação, procuramos estabelecer o que aqueles dispositivos e a racionalidade que os acompanha produzem e induzem a produzir nas subjetividades - o estudo da instituição escolar como exploração de mecanismos que estabelecem rigorosa aderência aos procedimentos e as formas e situações nas quais a ação pode representar a rejeição de qualquer manifestação de fatalismo e de alternativas aparentemente inescapáveis, reconfigurando o espaço de ensino.

É sempre importante, numa análise que pretende exercitar a expansão do entendimento, não "dar as costas" a autores, pensadores e pesquisadores que auxiliem, com suas contribuições, no desvelamento mais apurado da realidade, assim como é crucial, nesse propósito, não se tornar refém dos pensamentos de um único e determinado autor. Também adquire relevância para nós, precisamente, explorar a atualidade do diagnóstico de autores como Hannah Arendt, Michel Foucault e Zygmunt Bauman a respeito do presente, ou seja, realçar suas reflexões e mobilizá-los com o intuito de expandir a compreensão sobre os desdobramentos da ação em meio à racionalidade instrumental-legal que se encarna na burocracia estatal, tendo como âmbito a rede oficial de ensino. ${ }^{7}$

Com relação à instância política na qual está inserido o âmbito dessa análise, é preciso lembrar que estamos nos movendo numa esfera estadual. $\mathrm{O}$ uso que aqui adotamos do termo Estado (com letra maiúscula) marca a referência à administração pública estadual, portanto ao Estado federado e sua jurisdição autônoma.

Esse o cenário que, nos termos precedentes e de maneira introdutória, descortinamos sob nosso ponto de vista. É preciso dizer que temos ciência das variadas dimensões relacionais presentes no contexto educacional. Ou seja, sabemos que a dimensão regulamentar é apenas um aspecto dentre a miríade de aspectos concernentes à estrutura dinâmica das

\footnotetext{
${ }^{7}$ Para as aproximações que pretendemos, nos atrelamos muito mais a autores do que à tradições teóricas específicas, ou seja, extraímos e utilizamos, de diferentes autores, perspectivas que nos interessam de perto, concedendo a cada fator o seu devido lugar. Com tal intuito, se nosso discurso aqui é feito de referências a grandes autores, é porque reconhecemos neles grandes iluminações. Ainda assim, não é possível esperar que sempre afirmemos as mesmas coisas e os mesmos entendimentos sustentados por eles, simplesmente porque não falamos do mesmo ponto de vista.
} 
escolas. Entretanto, é nosso intuito nos concentrarmos na dimensão legalista e em seus efeitos práticos, como escolha de análise e opção de abordagem.

Geralmente, as abordagens de questões dessa natureza concentram-se e fixam o olhar sobre o Estado-Nação. A despeito de sua indubitável importância no contexto federativo, consideramos necessário aproximar o olhar e vislumbrar o que exatamente está acontecendo no âmbito de instituições como a escola, cuja proximidade com a instância estadual de decisões resulta em significativas e sistemáticas "obrigações de fazer". ${ }^{8}$ Nesse sentido, a análise que segue está centrada na recomendação de Foucault (2006b, p. 237) segundo a qual é preciso "descer ao estudo das práticas concretas" ao abordar o Estado. Essa abordagem está orientada também para as práticas de "governamentalidade" do Estado (FOUCAULT, 2006a), o que aparenta se traduzir não apenas na edição sistemática de regras, mas na prerrogativa desses instrumentos, compondo uma estratégia de "governamentalização" por excelência.

Nesse sentido, não se trata aqui de reconstituir todas as implicações possíveis quando se fala desse manto de "governamentalidade". Não pretendemos considerar fio por fio, mas, ao contrário, puxar alguns deles e atentar para suas características, seu alcance, as formas que podem assumir e o que podem suscitar. O trabalho de se aproximar de um manto muito bem "costurado" e procurar "desmanchá-lo" tem seu início por toda uma atividade legislativa, de caráter permanente; pela consideração de mecanismos redigidos, reescritos e reformados, contínuos, reguladores - concebidos não apenas como um conjunto de interdições, mas que "funciona cada vez mais como norma" (FOUCAULT, 1988, p. 157), estabelecendo o rigor dos procedimentos "normais" da instituição. Em seguida, nos aproximamos das situações, das relações cotidianas estabelecidas, dos vínculos criados com aquela legalidade e das oscilações plausíveis entre legalidade e ilegalidade.

\footnotetext{
${ }^{8} \mathrm{O}$ caso brasileiro, neste e em outros contextos, é realmente peculiar. Quando o assunto é "poder público", não há vozes que não deixam de se referirem ao termo 'Brasil' ou ao Estado brasileiro, ignorando a realidade federativa da Nação. É sintomático que as alegações de responsabilidade ou ausência de iniciativas - em geral disseminadas por "especialistas" e jornalistas, provavelmente atados a alguma noção ideológico-partidária recaíam sobre o âmbito federal ou nacional, deixando de lado o papel e a preponderância dos âmbitos locais, especialmente dos Estados federados e suas administrações. Tudo se passa como se os assuntos estaduais, notadamente suas faces negativas, fossem o produto de esquemas nacionais, intencionalmente imputados a uma suposta dinâmica federal ou generalizados como a face de uma nação "doente". Nesse engodo, as administrações estaduais aparecem como "vazios institucionais" sem relevância (as quais ressurgem e restabelecem suas relevâncias na propaganda de si mesmas, ao construírem positividades ou uma "agenda positiva") quando, na verdade, representam esferas autônomas (sob as quais estão subordinadas, por exemplo, as instituições escolares em suas jurisdições), nas quais se desenvolve um forte e influente campo burocrático de regulação e decisão sobre aspectos sociais, estatais e de governo. De acordo com Fukuyama (2005, p. 99), "a delegação de autoridade aos governos estaduais [...] em países em desenvolvimento implica, com frequência, o fortalecimento de elites locais ou de redes de influência que lhes permitem manter o controle sobre seus próprios negócios, distante do escrutínio externo".
} 
Nossa perspectiva está pautada no presente. A partir da observação das singularidades, procuramos explorar noções e aspectos de forma a torná-los gradualmente mais específicos e inteligíveis. O importante é vislumbrar o que os indivíduos estão fazendo. A compreensão disso depende da análise de seus modos de ação, de expressão e de sua situação institucional. A análise empreendida é uma avaliação, um traçar de afirmações a partir da conjuntura que se apresenta, dos cenários estabelecidos. Nesta tarefa, o que pretendemos não é a exaustão do detalhe, mas uma visão amplificada de atores num sistema institucional que atua para estabelecer duradouras disposições administrativas. 


\section{CAPÍTULO 1 \\ A REGULAMENTAÇÃO ESTATAL}

Todos os governantes [...] protegem zelosamente seus territórios de caça e, assim, o seu direito de estabelecer propósitos. [...] Os propósitos são alcançados, o caos é enxotado para fora do portão e a ordem é estabelecida no território.

Bauman, 1999.

Este capítulo é dedicado à discussão do ordenamento racional e deliberado do poder público sobre a estrutura de funcionamento das escolas, padronizando sua atuação por meio de regulamentos oficiais. A análise está centrada no instrumento de publicações estatais e fonte das regras legais - o Diário Oficial.

\subsection{Dimensões e aspectos na publicação regulamentar}

Os anos de 2007 e 2008 foram marcados pelo início de uma administração estadual, ${ }^{9}$ disseminando suas pretensões e planos de governo por meio do aparato regulamentar. Durante esse período (como é possível constatar nas Tabelas 1 e 2) milhares de regulamentos e diretivas foram publicadas nesse grande instrumento revelador das decisões estatais: o Diário Oficial. A necessidade de considerar as regulamentações ainda em vigor no cotidiano escolar guiou nossa opção por não recuar na linha temporal em demasiado, nos atendo ao biênio supracitado. Com o trabalho de campo realizado também no início de outra administração estadual, ${ }^{10}$ observamos a implantação de ações e técnicas tendo sempre como fundamento um dispositivo legal.

A despeito da labiríntica estrutura desse instrumento de publicidade oficial, bem como dos próprios textos publicados, procuramos acompanhar sua dinâmica, analisando todos os tipos de regulamentações, principalmente decretos, leis, resoluções e portarias, e nos

\footnotetext{
${ }^{9}$ Nas eleições de 2006, José Serra foi eleito governador do Estado de São Paulo pelo Partido da Social Democracia Brasileira (PSDB) para o mandato do período 2007-2010, com Alberto Goldman, também do PSDB, eleito vice-governador.

${ }^{10}$ A realização da pesquisa empírica ocorreu no primeiro ano do mandato do governador Geraldo Alckmin, eleito pelo PSDB (período 2011-2014).
} 
concentrando naquelas diretrizes que previram ações e providências organizacionais sobre aspectos relacionados à administração cotidiana no contexto escolar.

Tabela 1 - Publicações de atos regulamentares em 244 edições do Diário Oficial - ano 2007

\begin{tabular}{lcccc}
\hline $\begin{array}{c}\text { Atos } \\
\text { regulamentares }\end{array}$ & $\begin{array}{c}\text { Quantidade } \\
\text { publicada }\end{array}$ & $\begin{array}{c}\text { Número de } \\
\text { edições sem } \\
\text { publicação do } \\
\text { respectivo ato }\end{array}$ & $\begin{array}{c}\text { Mês com o maior } \\
\text { número de } \\
\text { publicações, por } \\
\text { ato normativo, e } \\
\text { quantidades }\end{array}$ & $\begin{array}{c}\text { Maior quantidade de } \\
\text { publicações constatada em } \\
\text { uma única edição, por ato } \\
\text { normativo }\end{array}$ \\
\hline $\begin{array}{l}\text { Decretos } \\
\begin{array}{c}\text { Portarias (exclusivas da } \\
\text { área educacional - } \\
\text { COGSP) }\end{array}\end{array}$ & 1156 & 16 & Dezembro (169) & 33 (edição 243 - dezembro) \\
$\begin{array}{l}\text { Resoluções (exclusivas } \\
\text { da área educacional } \\
- \text { COGSP) }\end{array}$ & 103 & 0 & Dezembro (912) & 67 (edição 244 - dezembro) \\
Leis & 247 & 180 & Agosto (14) & 7 (edição 240 - dezembro) \\
\hline
\end{tabular}

Tabela 2 - Publicações de atos regulamentares em 246 edições do Diário Oficial - ano 2008

\begin{tabular}{|c|c|c|c|c|}
\hline $\begin{array}{c}\text { Atos } \\
\text { regulamentares }\end{array}$ & $\begin{array}{l}\text { Quantidade } \\
\text { publicada }\end{array}$ & $\begin{array}{l}\text { Número de } \\
\text { edições sem } \\
\text { publicação do } \\
\text { respectivo ato }\end{array}$ & $\begin{array}{l}\text { Mês com o maior } \\
\text { número de } \\
\text { publicações, por } \\
\text { ato normativo, e } \\
\text { quantidades }\end{array}$ & $\begin{array}{c}\text { Maior quantidade de } \\
\text { publicações constatada em } \\
\text { uma única edição, por ato } \\
\text { normativo }\end{array}$ \\
\hline Decretos & 1361 & 7 & Dezembro (198) & 28 (edição 245 - dezembro) \\
\hline $\begin{array}{l}\text { Portarias (exclusivas da } \\
\text { área educacional - } \\
\text { COGSP) }\end{array}$ & 7289 & 0 & Dezembro (777) & 61 (edição 242 - dezembro) \\
\hline $\begin{array}{l}\text { Resoluções (exclusivas } \\
\text { da área educacional } \\
\text { - COGSP) }\end{array}$ & 99 & 176 & Novembro (17) & $\begin{array}{c}4 \text { (edição } 26 \text { - fevereiro) } \\
4 \text { (edição } 212 \text { - novembro) }\end{array}$ \\
\hline Leis & 391 & 186 & Abril (72) & 31 (edição 57 - março) \\
\hline
\end{tabular}

Fonte: Diário Oficial do Estado de São Paulo. Poder Executivo, Seção I.

O conhecimento sobre a dinâmica legislativa do Estado exigiu um acompanhamento sistemático dos mais variados textos publicados em cada edição do Diário Oficial, uma vez que eles são contínuos e que "existem tantas normas quantos tipos de atividade a federar" (EWALD, 2000, p. 123). Nesse espaço, eles proliferam e se reproduzem, na exata medida em 
que o assunto de uma lei exige sua regulamentação por meio de um decreto, e este a operacionalização das ações exigidas por meio de uma resolução ou de uma portaria. Todos esses elementos são fatores multiplicadores, que carregam em si o germe de novas regulamentações - uma parafernália rotativa em busca do perpétuo respaldo legal.

Durante cerca de oito meses $^{11}$, as publicações dos documentos oficiais foram abordadas em extensão e estruturadas em informações comparáveis, a partir dos atos do Poder Executivo paulista em seu Caderno específico.

A aproximação ao Diário Oficial como instrumento de pesquisa revela uma profusão de atos de toda ordem: atos de efeitos gerais, administrativos, regulatórios, procedimentais. Nele estão contidos os discursos oficiais legitimados. Esses atos estão disseminados por toda a estrutura do jornal oficial e é muito fácil se perder entre eles. Ao analisar o Diário Oficial da União, Soares (2004, p. 288) destaca igualmente que "a leitura do DOU e a busca dos atos objeto de publicação constitui-se numa verdadeira 'odisseia' para os desavisados".

No período, excetuando as decisões sobre vida funcional, as publicações - inclusive sobre as unidades de ensino -, totalizaram 19.330 peças regulamentares, o que representa, em média, cerca de 27 atos publicados a cada dia (entre decretos, portarias, leis e resoluções). ${ }^{12}$ Em toda a sua extensão, a estrutura das edições no biênio analisado foi composta por mais de 69 mil páginas.

O frenesi de publicações obedece a uma rigorosa rotina: todos os dias há algum ato a ser publicado, sempre tendo como referência acertos e decisões realizadas no dia anterior. ${ }^{13}$ De 2007 a 2008, 62\% dessas decisões foram publicadas entre quarta e sexta-feira - conforme é possível constatar nos Gráficos 1 e 2 .

\footnotetext{
${ }^{11}$ A pesquisa dos atos regulamentares se estendeu de 12/2010 a 08/2011, período que se revelou mais extenso do que nossas expectativas iniciais, em virtude da necessária análise sistemática, página a página, mas principalmente em virtude de um fator técnico imprevisto. De acordo com as informações obtidas na sede da Imprensa Oficial do Estado de São Paulo, no setor de Pesquisa ao Diário Oficial, com o processo de digitalização do acervo não são disponibilizadas para consultas as edições impressas do Diário Oficial. Somente é possível ter acesso às edições impressas de um curto período - as últimas sete edições mais recentes. Por essa razão, as consultas foram realizadas por meio do endereço eletrônico da Imprensa Oficial, uma vez que todas as edições - inclusive dos anos de 2007 e 2008 - estão digitalizadas na íntegra e certificadas, garantindo a autenticidade do conteúdo por meio de certificação digital (IMPRENSA OFICIAL DO ESTADO DE SÃO PAULO, 2011). Essa operação se mostrou bastante onerosa, notadamente em termos de tempo, uma vez que cada página das respectivas edições referentes aos anos de 2007 e 2008 precisou ser carregada separadamente, sendo uma por vez, para que fosse possível obter o acesso às informações de toda a edição publicada. Além disso, a lentidão no tráfego de informações nos servidores virtuais do endereço eletrônico da Imprensa Oficial dificultou a obtenção mais célere das informações.

${ }^{12}$ Considerando apenas os decretos, em 2007 o montante correspondente representou, em média, 3 (três) decretos por dia. Já a regularidade de atos decretados em 2008 representou, em média, 4 (quatro) a cada dia. Se considerarmos as leis, a média de publicações é de uma por dia durante este último ano.

${ }^{13}$ As únicas exceções se referem aos domingos e segundas, nos quais não há edições publicadas. Como não há expediente nos finais de semana, essas edições não possuem substrato para serem publicadas. $\mathrm{O}$ mesmo acontece nos feriados.
} 
De maneira geral, os atos presentes no conjunto de edições previram providências administrativas, ao mesmo tempo em que estabeleceram um "caminho", um "modo de fazer", regras de procedimento. O conjunto averiguado introduziu, em maior ou menor medida, formas oficiais de organizar as instituições públicas.

Gráfico 1 - Publicação de atos regulamentares segundo os dias da semana - ano 2007*

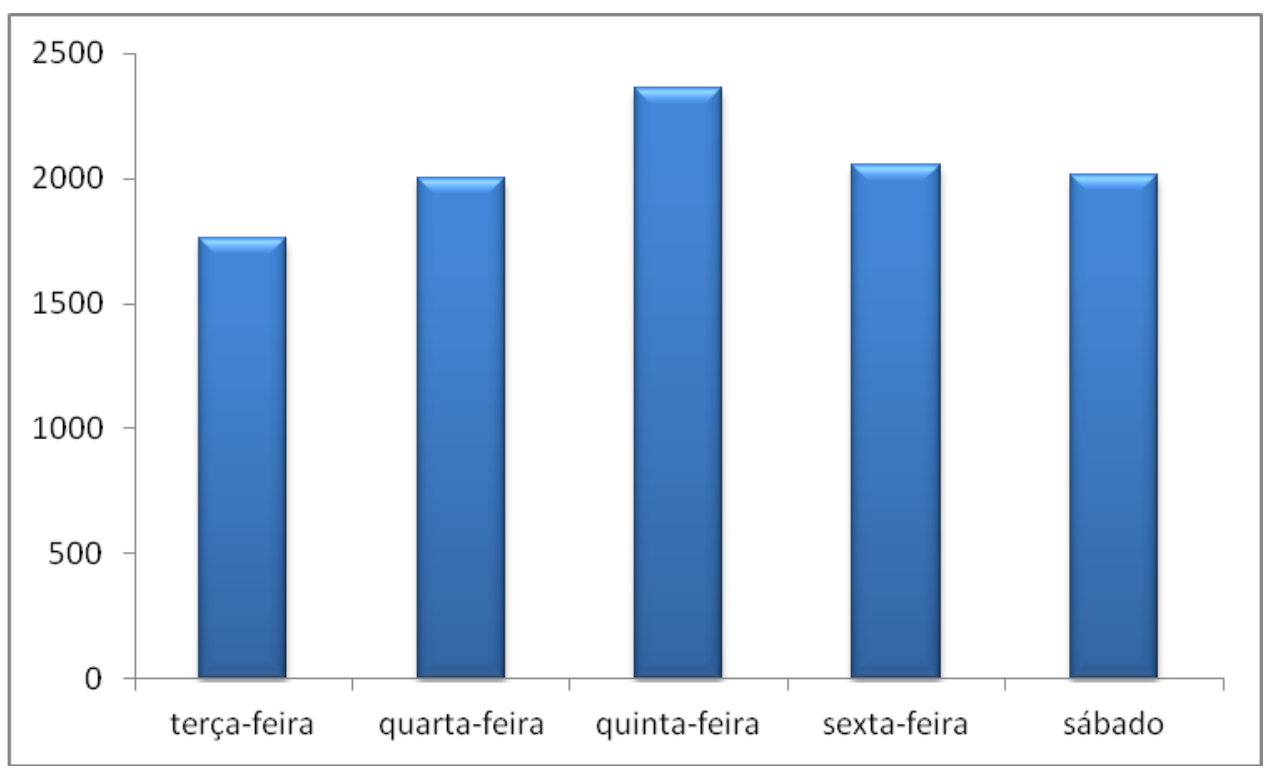

Fonte: Diário Oficial do Estado de São Paulo. Poder Executivo, Seção I.

*Decretos, portarias, leis e resoluções.

Gráfico 2 - Publicação de atos regulamentares segundo os dias da semana - ano 2008*

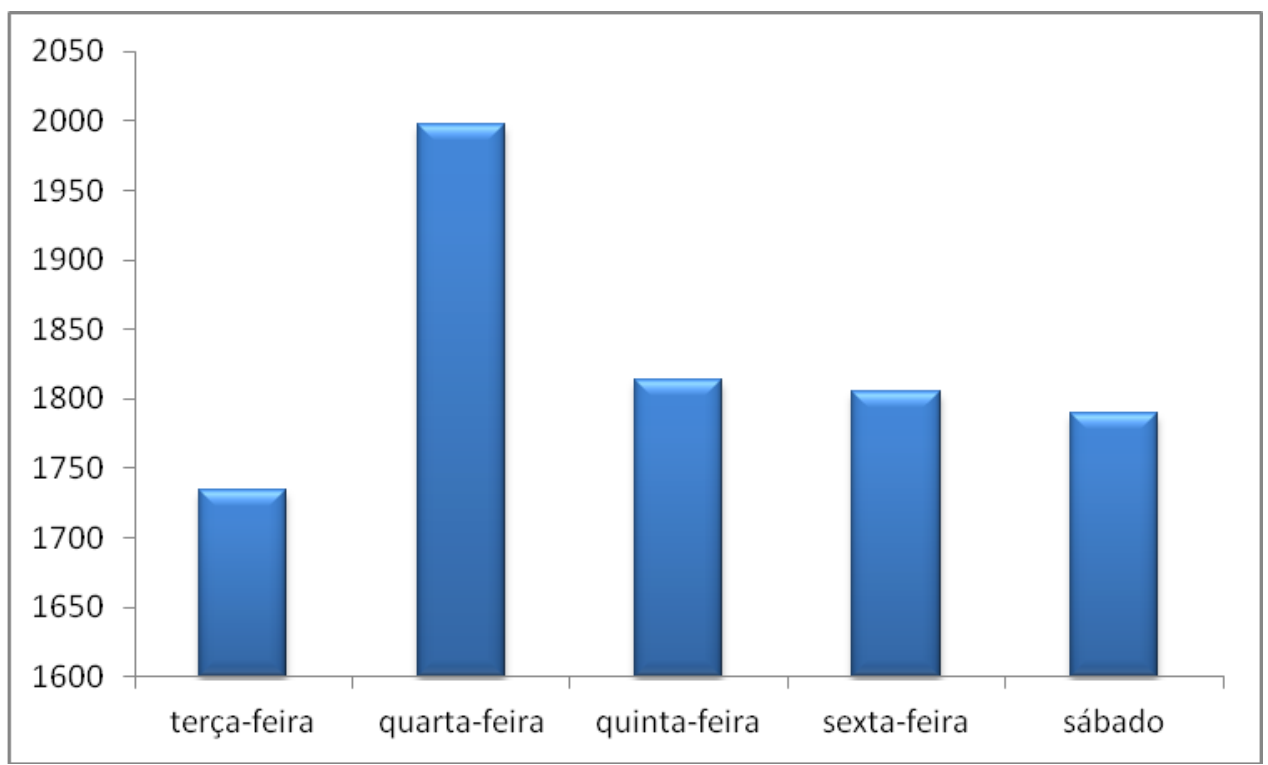

Fonte: Diário Oficial do Estado de São Paulo. Poder Executivo, Seção I.

*Decretos, portarias, leis e resoluções. 
No emaranhado de atos de governo constatamos que entre os anos de 2007 e 2008 foram publicadas 980 edições do Diário Oficial, referentes ao caderno do Poder Executivo nas suas Seções I (atos normativos e de interesse geral, regras legais e decisões sobre a instituição escolar) e II (atos administrativos e de interesse dos servidores, decisões burocráticas sobre a vida funcional dos indivíduos). Parece conveniente esclarecer que os atos publicados na Seção I possuem caráter geral e estão relacionados à administração das instituições e aos procedimentos a serem observados de maneira coletiva. Os atos publicados na Seção II remetem, precipuamente, a acertos e regularizações de aspectos relacionados ao andamento das carreiras do serviço público - inclusive as admissões e dispensas de novos servidores -, possuindo um caráter individualizante e uma forma nominal.

Gráfico 3 - Portarias de admissões e dispensas (movimentação de pessoal) - ano 2007*

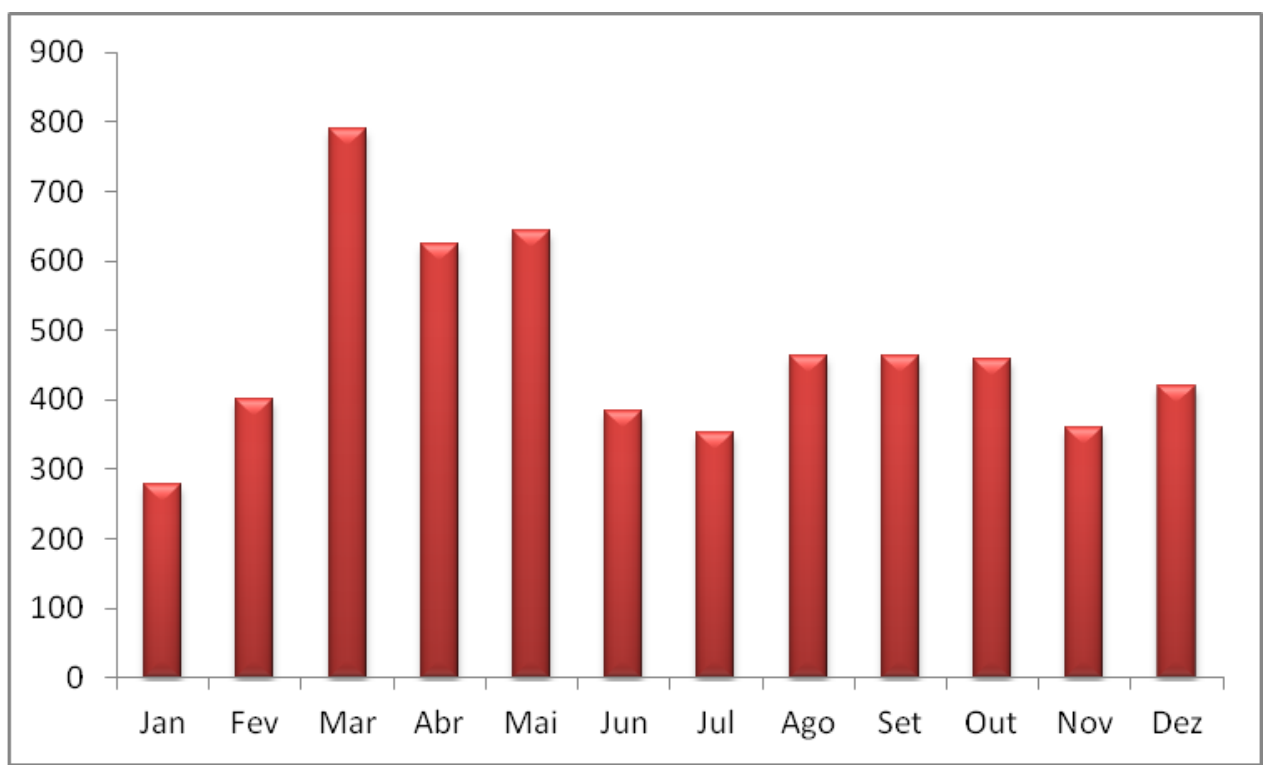

Fonte: Diário Oficial do Estado de São Paulo. Poder Executivo, Seção II.

*Exclusivas da área educacional - COGSP

Nesta última Seção, as portarias são os documentos que regem essas regularizações e contratações. Já em relação à Seção I, na qual podemos observar que, em 2007, mais de 8 mil portarias foram editadas e, em 2008, mais de 7 mil, elas se referem ao contexto administrativo e institucional do universo da rede de ensino, compondo as regularizações e decisões sobre aspectos estruturais de cada uma das escolas. As portarias são atos oficiais onipresentes durante os anos investigados.

Em termos numéricos, as oscilações de atos administrativos indicam graus distintos de variabilidade de um ano ao outro. Essas oscilações, no entanto, retratam dimensões 
eminentemente dinâmicas, que assumem diferentes intensidades, são reorganizadas ou refeitas de acordo com as escolhas políticas adotadas em termos de uma racionalidade gerencial, a qual prevê a obrigatoriedade de tornar público e buscar a produção de efeitos de eficiência e lisura no trato das questões institucionais públicas - mesmo que, de fato, não os produza. Nos planos em torno daquela racionalidade, as portarias parecem assumir um espaço preeminente.

Gráfico 4 - Portarias de admissões e dispensas (movimentação de pessoal) - ano 2008*

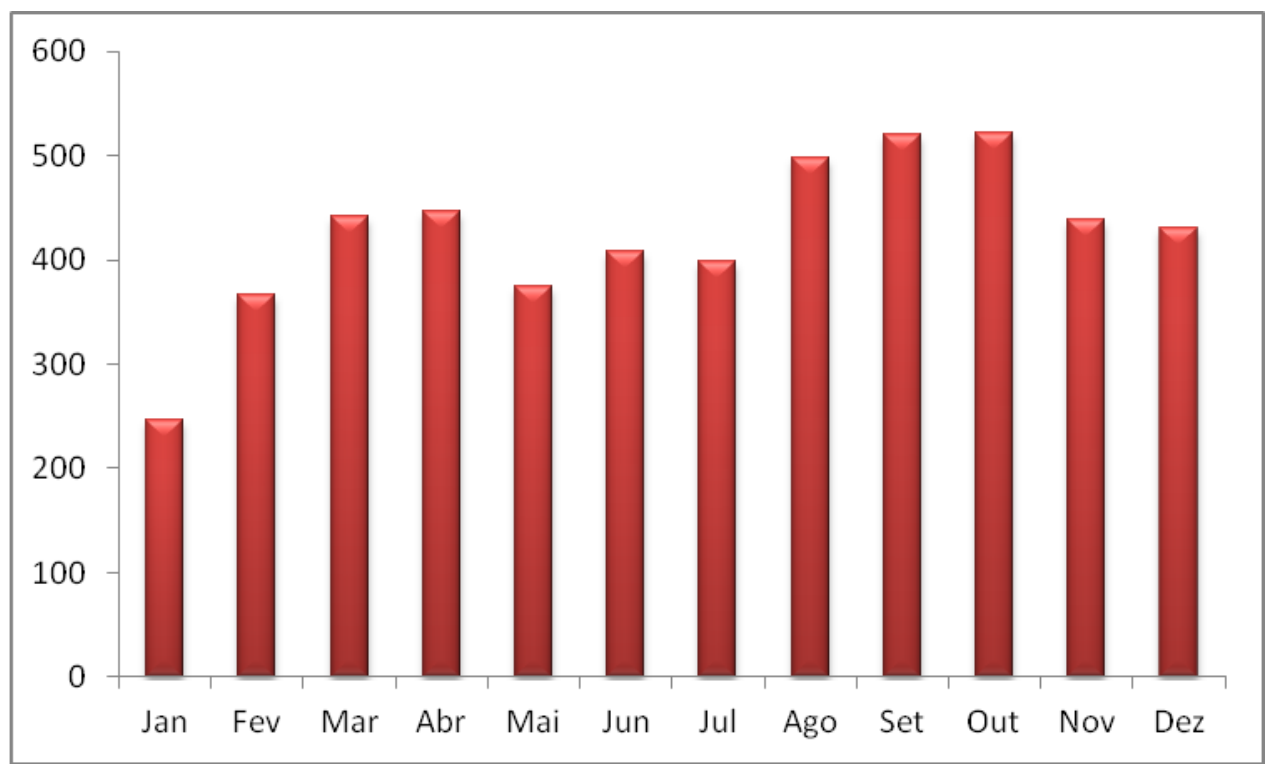

Fonte: Diário Oficial do Estado de São Paulo. Poder Executivo, Seção II. *Exclusivas da área educacional - COGSP

Gráfico 5 - Publicação de Portarias a respeito da situação funcional dos servidores - ano 2007*

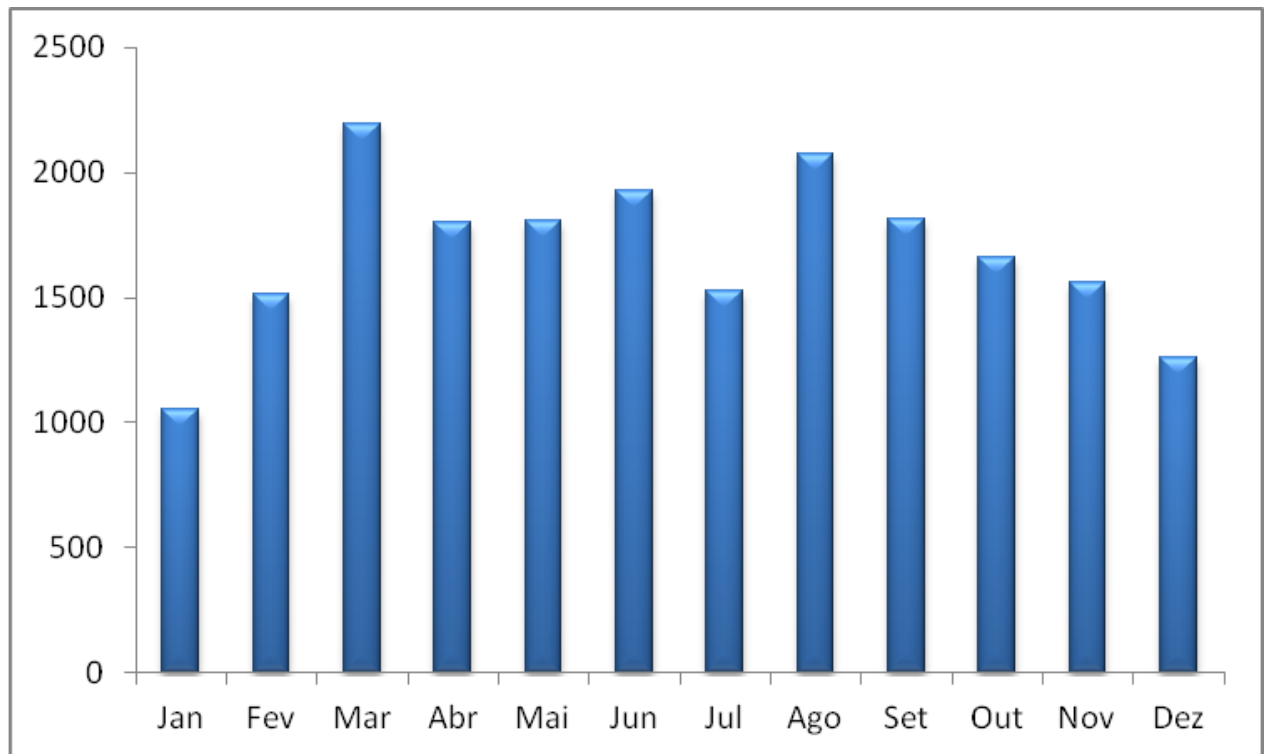

Fonte: Diário Oficial do Estado de São Paulo. Poder Executivo, Seção II. *Exclusivas da área educacional - COGSP 
Gráfico 6 - Publicação de Portarias a respeito da situação funcional dos servidores - ano 2008*

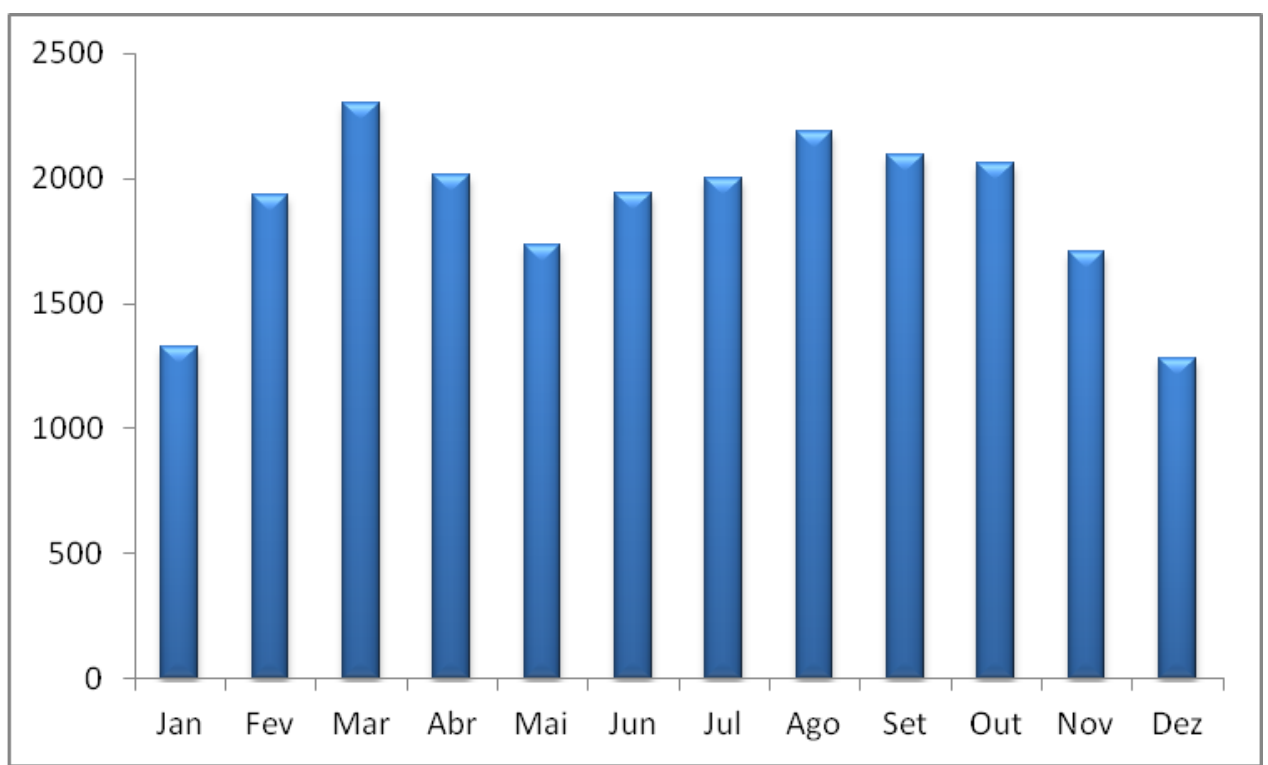

Fonte: Diário Oficial do Estado de São Paulo. Poder Executivo, Seção II. *Exclusivas da área educacional - COGSP

As dimensões representadas aqui estão relacionadas aos anos iniciais de uma administração governamental, mobilizando o cabedal de formas oficiais na tentativa de estabelecer seus planos - dinâmica que repercute na variedade de atos emitidos.

Tabela 3 - Outros atos publicados (âmbitos educacional e geral) - ano 2007

\begin{tabular}{lc}
\hline \multicolumn{1}{c}{ Ato normativo } & Quantidade publicada \\
\hline Instrução DRHU & 4 \\
Comunicado* & 27 \\
Portaria conjunta DRHU/CENP/COGSP/CEI & 3 \\
Portaria DRHU & 6 \\
Instrução conjunta COGSP/CEI/CENP/DRHU & 1 \\
Resolução conjunta - SF/SGP** & 1 \\
Comunicado DRHU & 5 \\
Resolução Casa Civil** & 1 \\
Lei Complementar & 33 \\
Instrução CENP & 3 \\
Decreto Declaratório & 1 \\
Veto (Parcial e Total) & 16 \\
Instrução UCRH & 2 \\
\hline
\end{tabular}

Fonte: Diário Oficial do Estado de São Paulo. Poder Executivo, Seção I.

* Exclusivo do âmbito educacional - COGSP.

** Envolve procedimentos no âmbito educacional. 
As diretrizes e decisões são elaboradas e reelaboradas de maneiras distintas, e os tipos de regulamentações encontradas assumem variabilidades e recebem novas dinâmicas de um ano ao outro, como é possível observar nas Tabelas 3 e 4.

Tabela 4 - Outros atos publicados (âmbitos educacional e geral) - ano 2008

\begin{tabular}{lc}
\hline \multicolumn{1}{c}{ Ato normativo } & Quantidade publicada \\
\hline Lei Complementar & 52 \\
Veto (Parcial e Total) & 21 \\
Comunicado* & 4 \\
Comunicado CENP & 2 \\
Portaria DRHU & 2 \\
Instrução CENP & 1 \\
Instrução DRHU & 1 \\
\hline
\end{tabular}

Fonte: Diário Oficial do Estado de São Paulo. Poder Executivo, Seção I.

* Exclusivo do âmbito educacional - COGSP.

A investigação do cenário regulamentar revelou também que, em maior ou menor grau, os alvos das orientações, procedimentos e diretrizes legais não são simplesmente o aluno e o professor: todos os atores imbuídos de alguma atividade são passíveis de alguma regulamentação. Os elementos que compõem o Diário Oficial formam um conjunto de instrumentos de organização, ordenamento, manipulação e administração social e institucional. Inseridos nessa trama, os indivíduos movem-se perante essa face pública e formam as conexões com discursos que convocam, deferem ou indeferem, declaram, homologam, substituem, autorizam, alteram, indicam, excluem, anulam, tornam sem efeito, aprovam, prorrogam, incluem, regularizam, ratificam, acrescentam, tornam insubsistente, afastam, concedem, interrompem, obrigam fazer. De fato, essas expressões, por vezes imperativas, assumem um lugar insistente no conjunto regulatório e administrativo, e são complementadas por outros termos que resolvem, decretam, promulgam, revogam e resolvem novamente, vetam, comunicam e instruem.

O espaço ocupado por esses termos e pelos instrumentos que os sucedem é significativo. Na Seção II pesquisada, entre $60 \%$ e $86 \%$ de cada edição esteve destinada à organização do âmbito educacional - o que envolve tomar decisões, estabelecer as regras e 
regularizar as situações funcionais de cada servidor público. Regularizar as vidas funcionais é uma constante diária das publicações oficiais. ${ }^{14}$

Os textos legais formam ciclos anuais e constituem uma série de regências institucionais, mobilizando ações, decisões, estruturas, meios técnicos, formando fluxos de entrada e saída de pessoal, estabelecendo as conexões acertadas para a administração de uma racionalidade que pretende ser sempre mais eficiente e produtiva na organização das instituições públicas. O panorama que assim se esboça pode ser observado no Gráfico 7 a seguir, no qual estão contemplados os totais publicados correspondentes aos decretos, leis, portarias e resoluções para os anos considerados.

Gráfico 7 - Publicação de atos regulamentares - São Paulo, 2007 e 2008

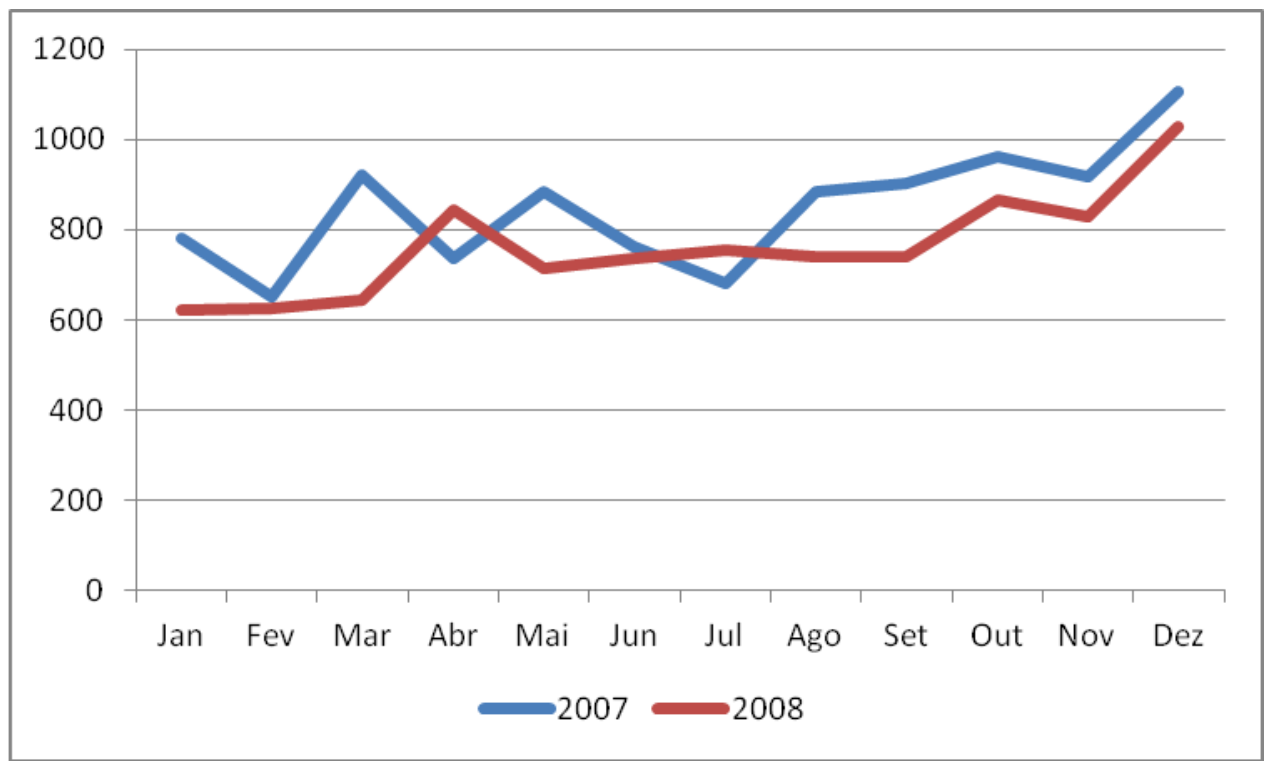

Fonte: Diário Oficial do Estado de São Paulo. Poder Executivo, Seção I.

Cabe ressaltar as curvas ascendentes nos finais dos anos pesquisados em relação aos atos publicados, notadamente nas últimas edições do mês de dezembro, o que pode sugerir não apenas uma preocupação com o lançamento das bases legais relacionadas à administração estatal visando ao exercício posterior, mas também uma obrigação, que acompanha toda essa racionalidade legalista, de legitimar uma série de perspectivas com novos atos administrativos e garantir assim a continuidade de instrumentos que foram usados no ano, a suspensão e

${ }^{14}$ Em 2007, foram publicadas 20.190 portarias desse tipo. No ano de 2008, o número de documentos editados chegou a 22.586 portarias publicadas. Consideradas no período 2007-2008, representaram, em média, 117 portarias editadas por dia. 
revogação daqueles que não produziram os efeitos de eficiência e produtividade esperados, e a caução legal para implantar outros que forem necessários no ano seguinte. Quando os atos são considerados de maneira isolada, é possível constatar que eles seguem um dinamismo similar, a despeito de suas variabilidades específicas, conforme ilustram os gráficos a seguir.

Gráfico 8 - Publicação de Decretos no ano de 2007

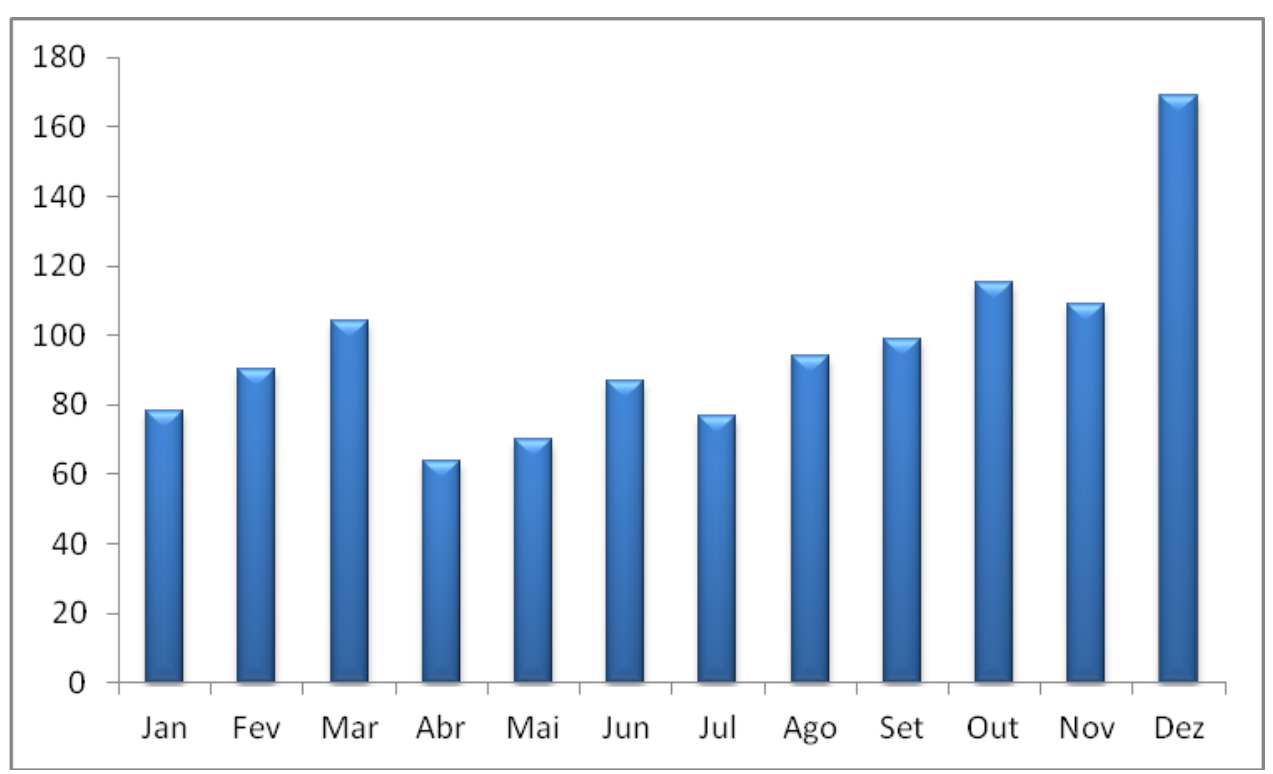

Fonte: Diário Oficial do Estado de São Paulo. Poder Executivo, Seção I.

Gráfico 9 - Publicação de Decretos no ano de 2008

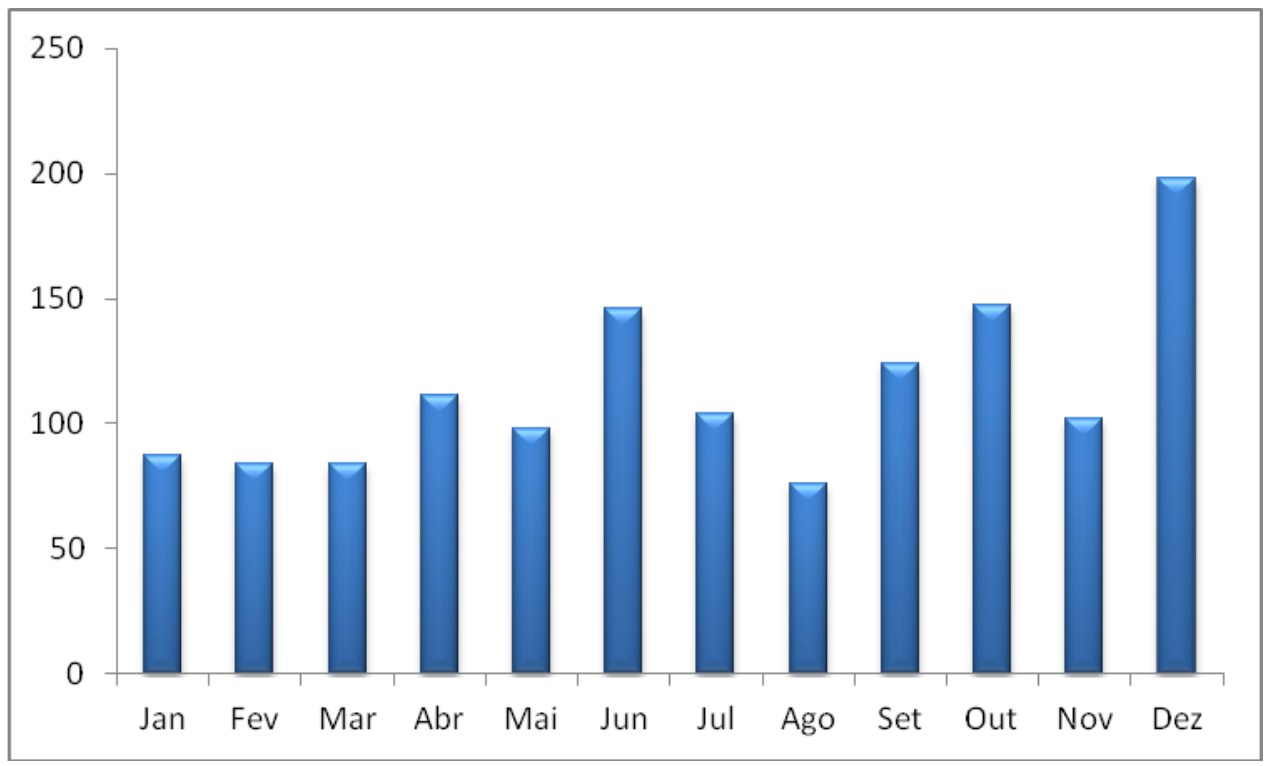

Fonte: Diário Oficial do Estado de São Paulo. Poder Executivo, Seção I. 
Gráfico 10 - Publicação de Leis no ano de 2007

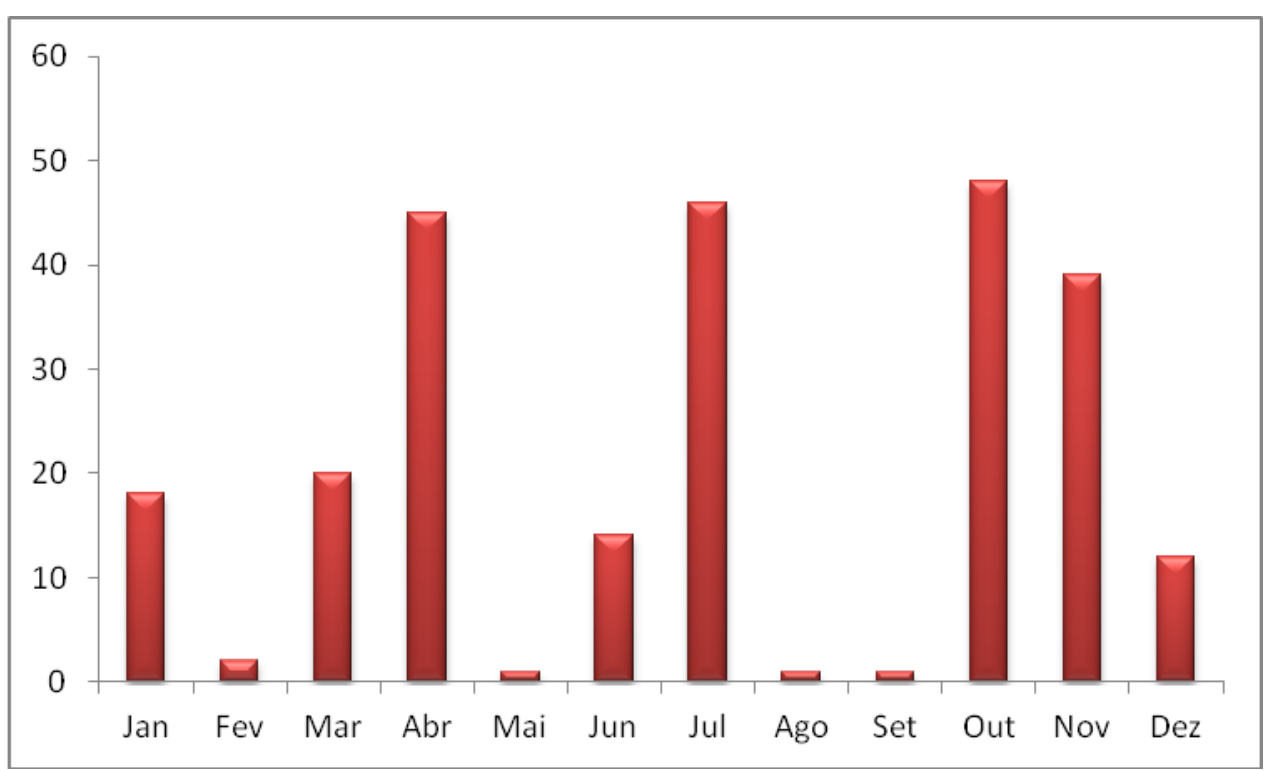

Fonte: Diário Oficial do Estado de São Paulo. Poder Executivo, Seção I.

Gráfico 11 - Publicação de Leis no ano de 2008

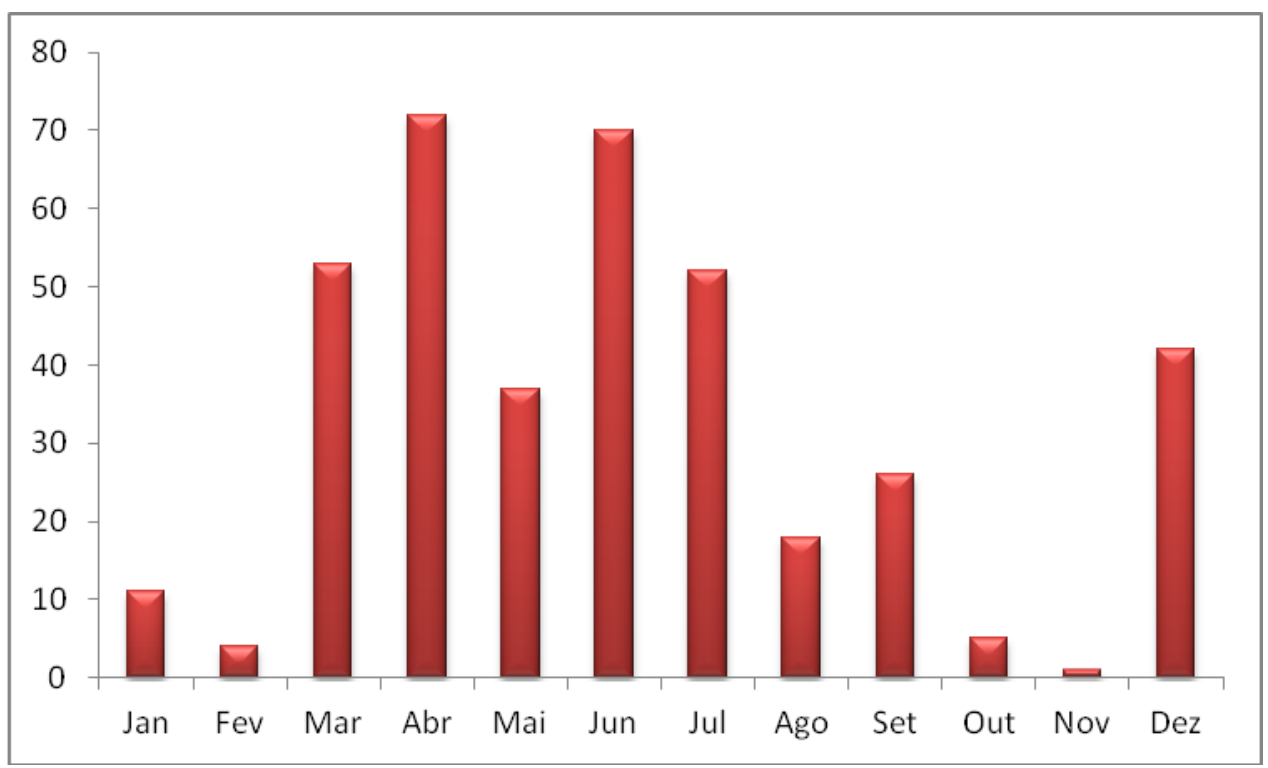

Fonte: Diário Oficial do Estado de São Paulo. Poder Executivo, Seção I.

De maneira geral, os finais dos anos são marcados por acréscimos no ritmo de regulamentação anual, como é possível observar. Dezembro se destacou como mês de grande concentração de decretos na administração pública estadual, com mais de 160 em 2007 e quase atingindo a marca de 200 decretos em 2008. Quando analisamos apenas as leis, constatamos uma dinâmica bastante variável durante os anos, com a intensificação de 
publicações nos três últimos meses de 2007, totalizando 99 leis - o que concentra $40 \%$ de tudo o que foi publicado no ano -, e uma maior disseminação durante o ano de 2008, com destaque para os meses de abril e junho.

Gráfico 12 - Publicação de Portarias no ano de 2007*

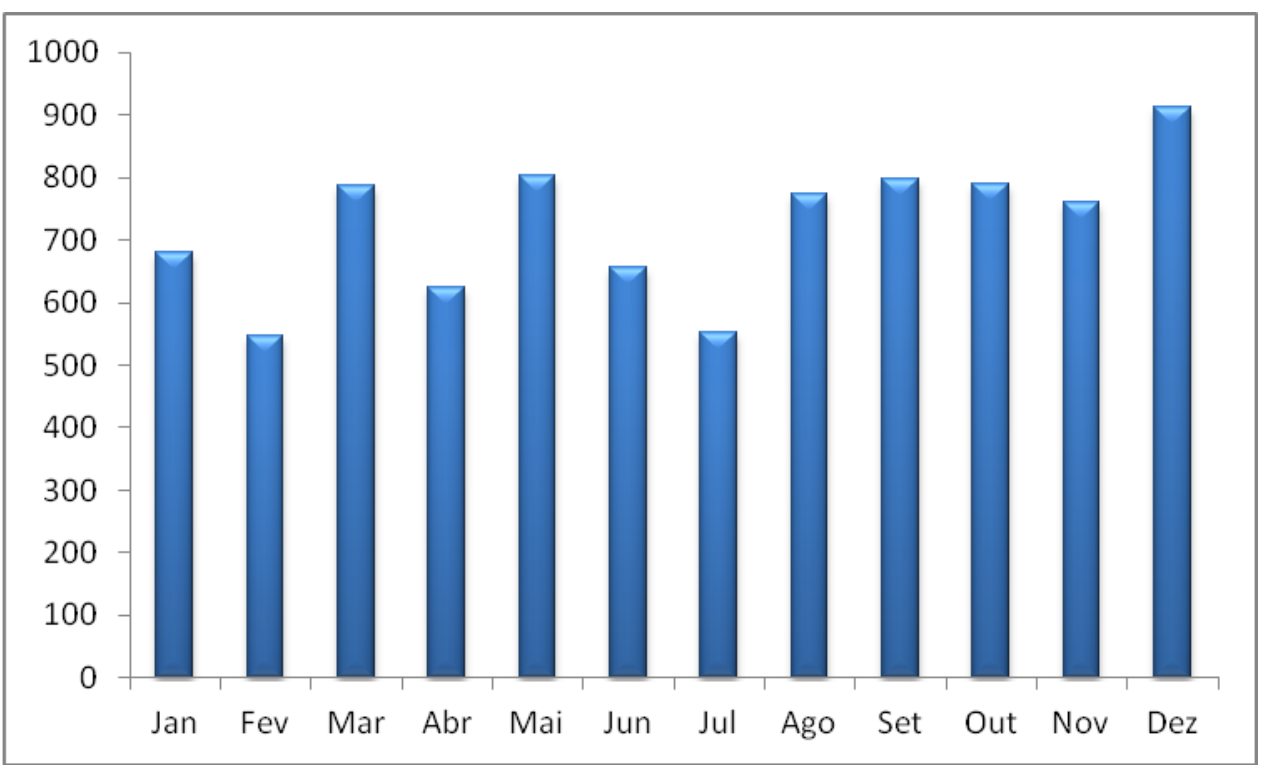

Fonte: Diário Oficial do Estado de São Paulo. Poder Executivo, Seção I.

*Exclusivas da área educacional - COGSP

Gráfico 13 - Publicação de Portarias no ano de 2008*

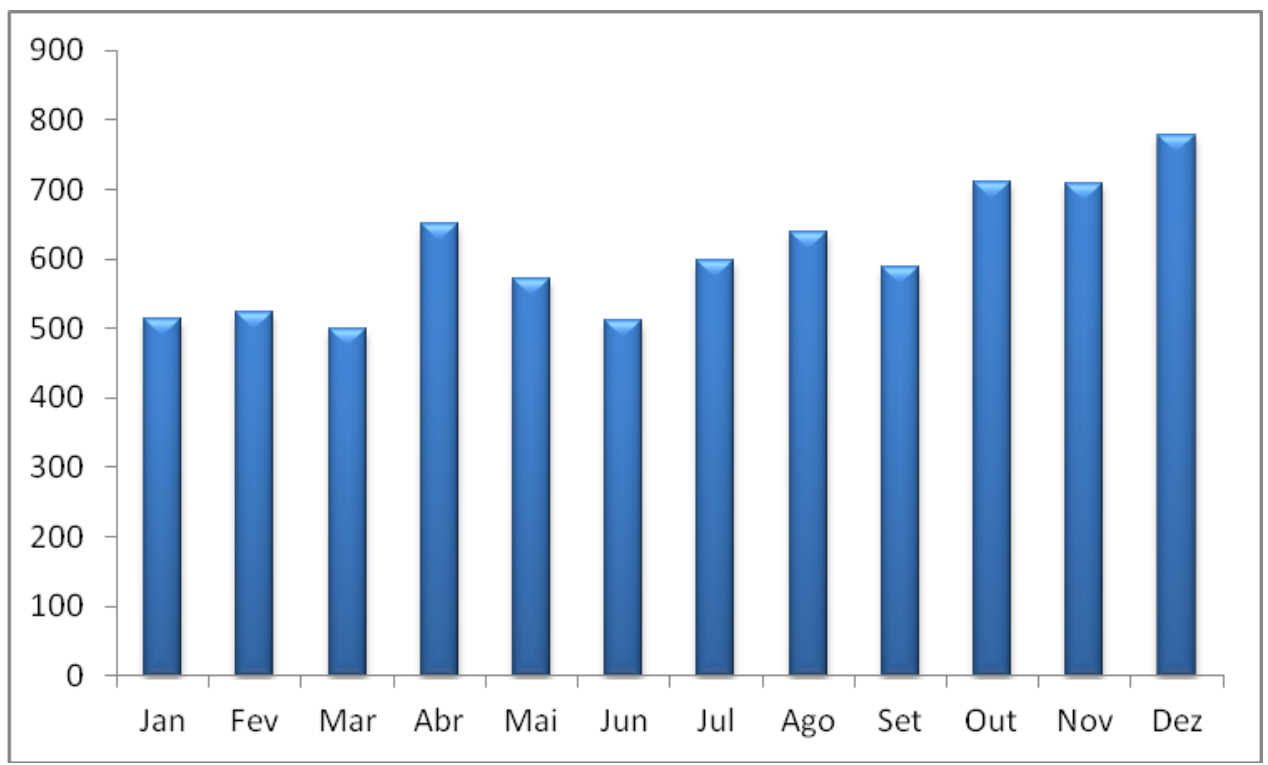

Fonte: Diário Oficial do Estado de São Paulo. Poder Executivo, Seção I.

*Exclusivas da área educacional - COGSP 
Gráfico 14 - Publicação de Resoluções no ano de 2007*

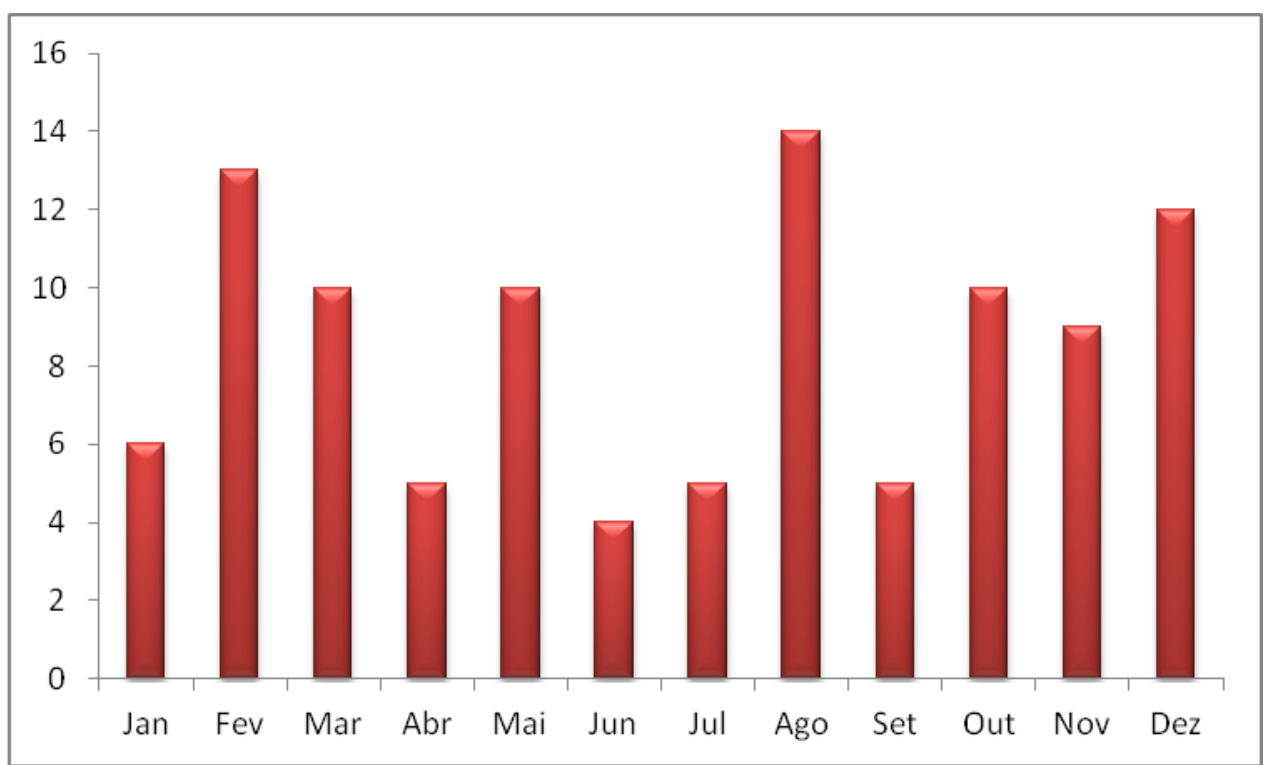

Fonte: Diário Oficial do Estado de São Paulo. Poder Executivo, Seção I. *Exclusivas da área educacional - COGSP

Gráfico 15 - Publicação de Resoluções no ano de 2008*

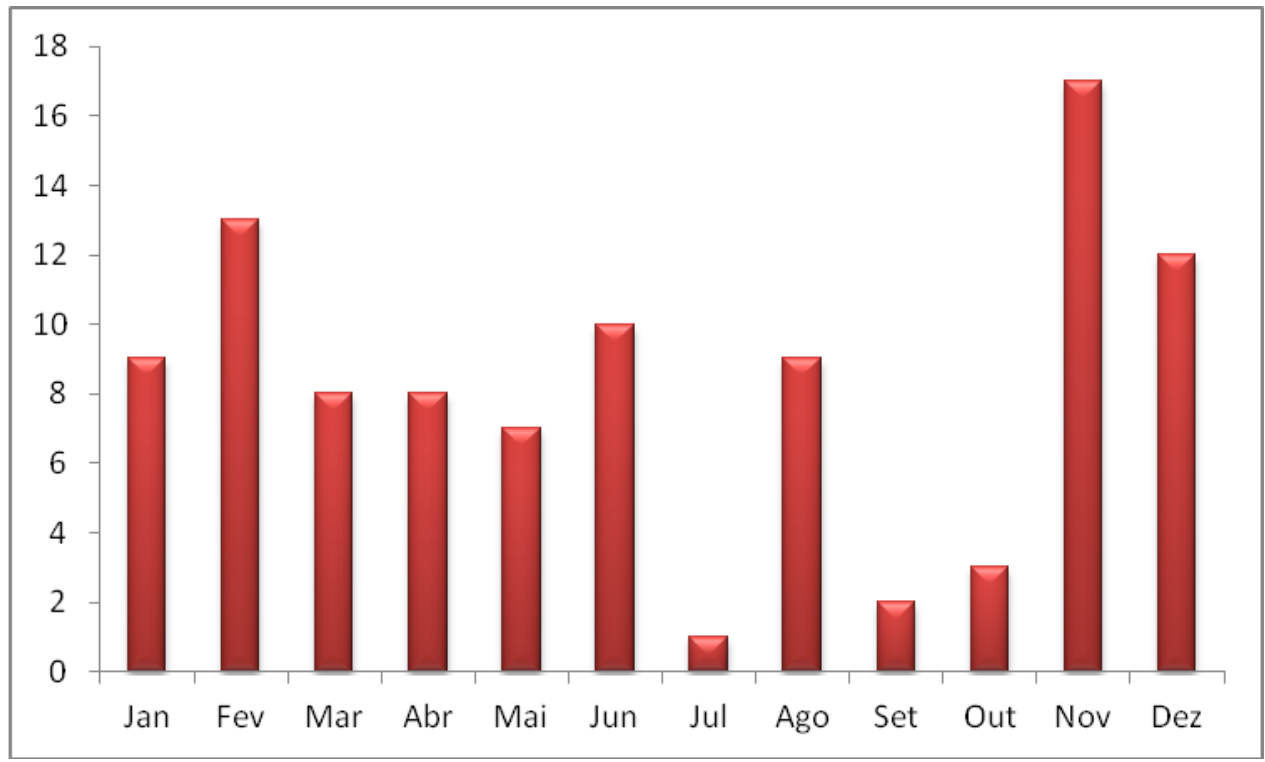

Fonte: Diário Oficial do Estado de São Paulo. Poder Executivo, Seção I.

*Exclusivas da área educacional - COGSP

É possível observar também aquela disseminação dos atos durante os anos quando se consideram as portarias e as resoluções publicadas, como ilustraram os gráficos precedentes.

Consideradas em seu conjunto, reunidas diariamente e mensalmente, aquelas dinâmicas durante os anos podem ser expressas no volume de páginas emitidas por mês, 
formando a dimensão física do Diário Oficial, tanto na Seção I como na Seção II - o espaço indispensável para divulgar as regras que dirigem e mantém as instituições públicas.

Gráfico 16 - Volume de páginas publicadas no ano de 2007 - Seção I

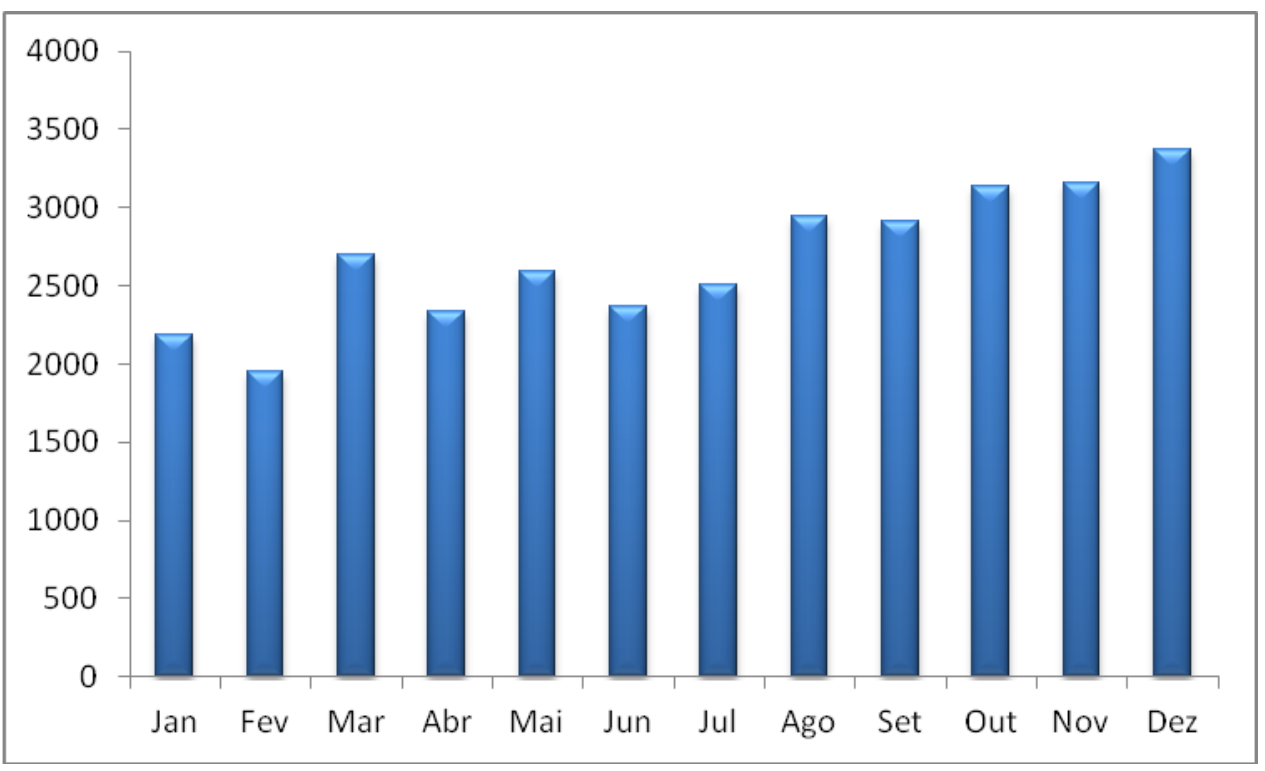

Fonte: Diário Oficial do Estado de São Paulo. Poder Executivo, Seção I.

Gráfico 17 - Volume de páginas publicadas no ano de 2008 - Seção I

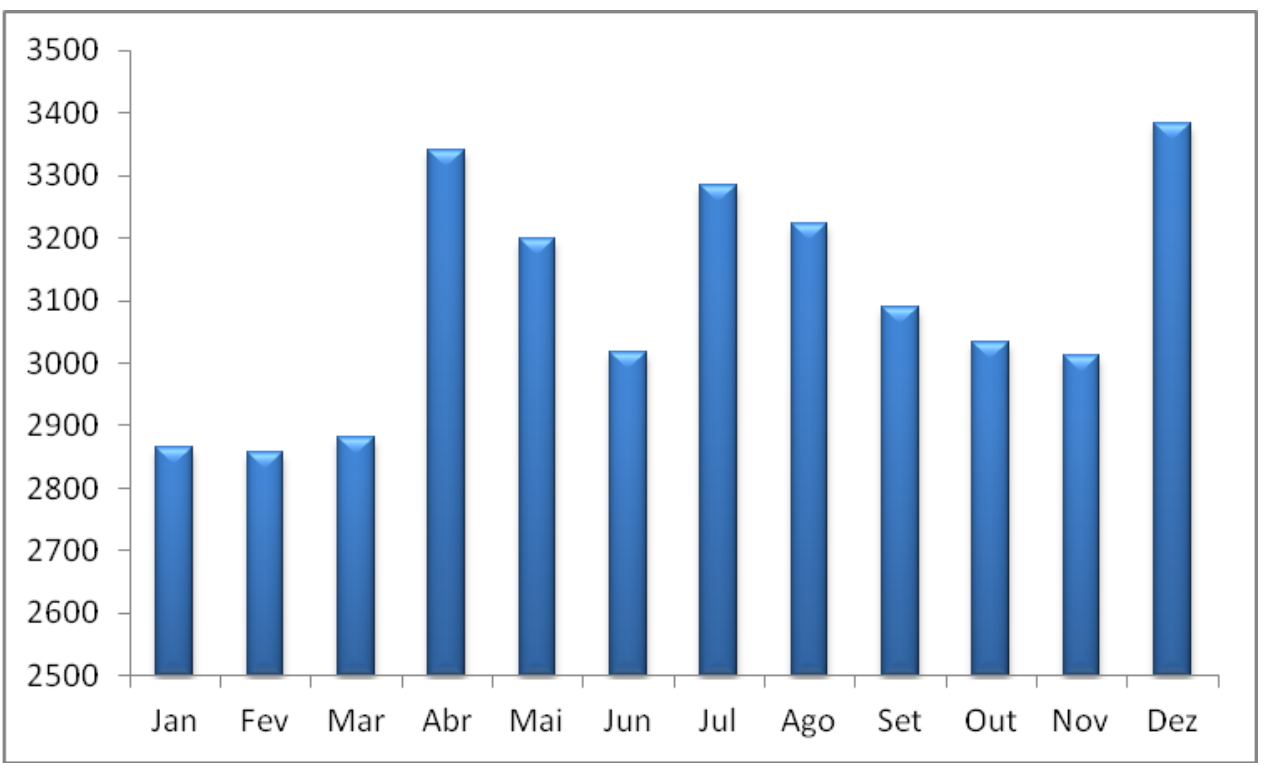

Fonte: Diário Oficial do Estado de São Paulo. Poder Executivo, Seção I. 
Gráfico 18 - Volume de páginas publicadas no ano de 2007 - Seção II

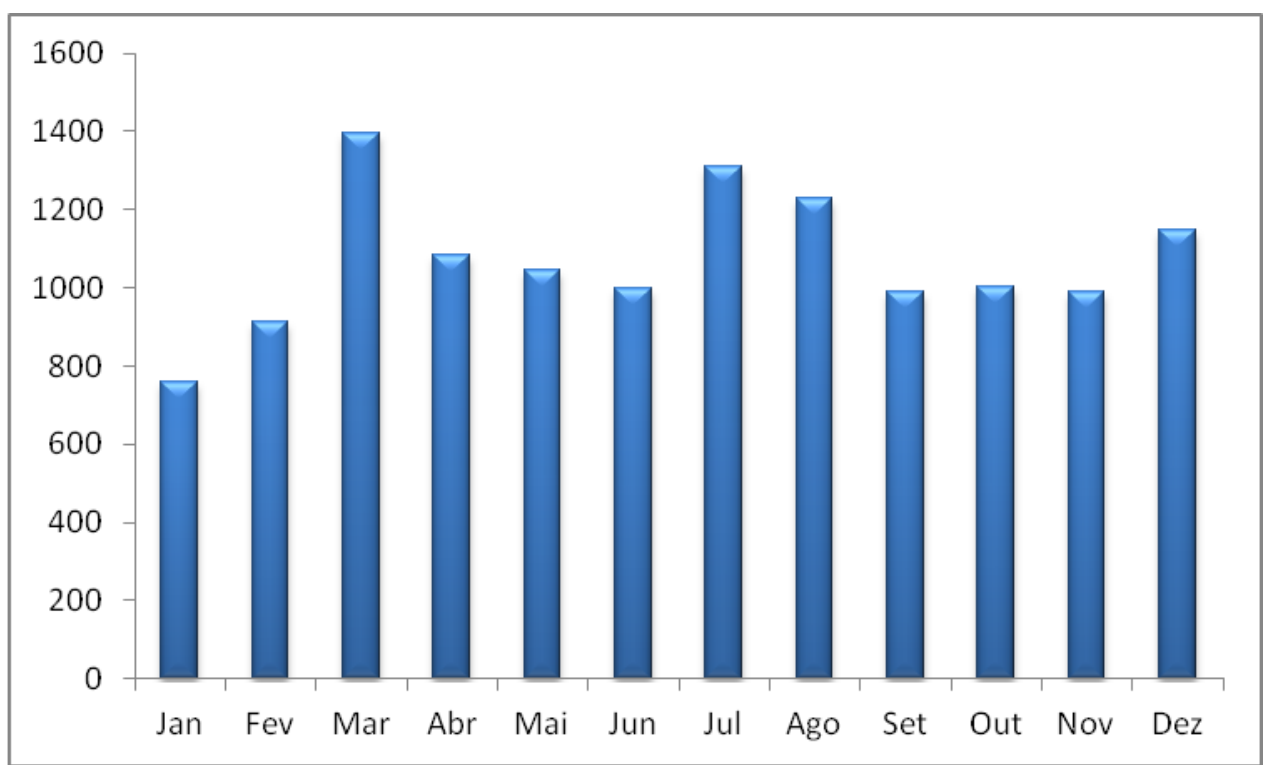

Fonte: Diário Oficial do Estado de São Paulo. Poder Executivo, Seção II.

Gráfico 19 - Volume de páginas publicadas no ano de 2008 - Seção II

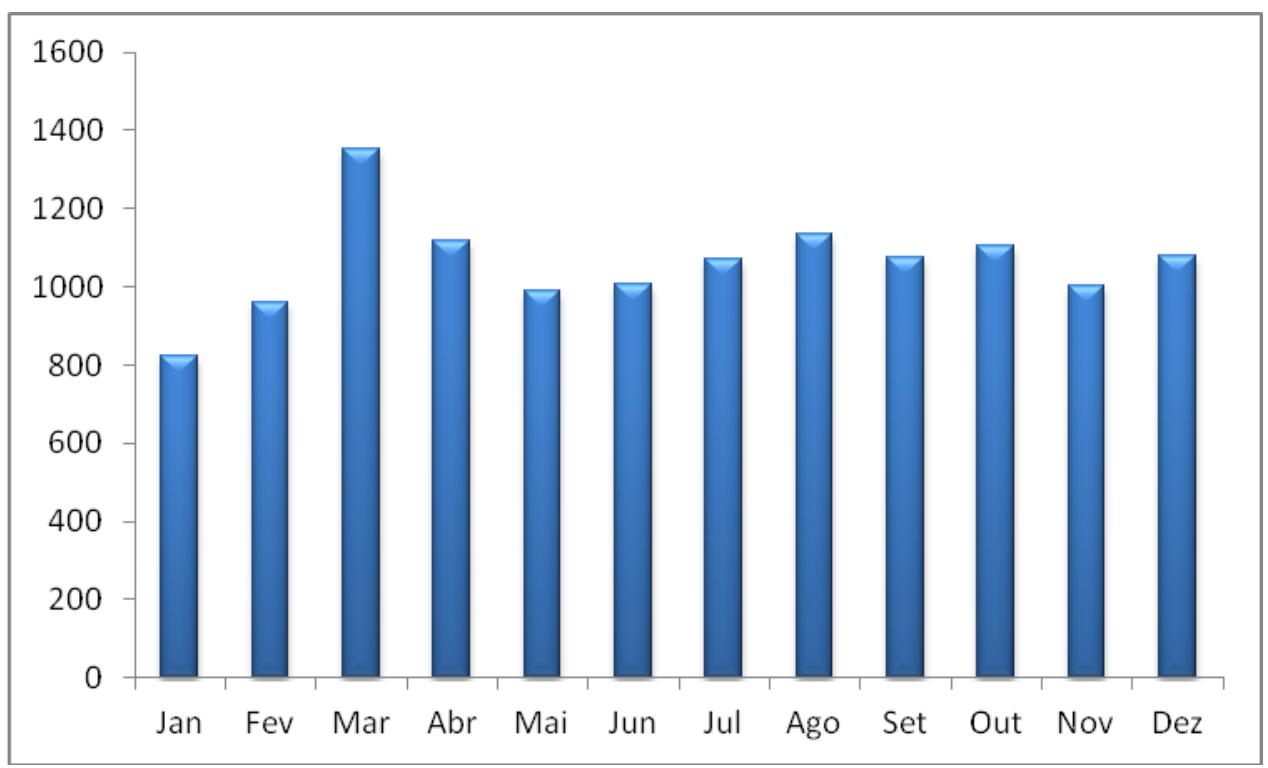

Fonte: Diário Oficial do Estado de São Paulo. Poder Executivo, Seção II.

O estudo dos atos publicados no Diário Oficial auxilia a demonstrar que os integrantes dos círculos decisórios, notadamente do Poder Executivo, estão constantemente atentos para os aspectos da máquina pública, e continuamente procuram aperfeiçoar práticas de regularização de seu aparato burocrático, disseminando instrumentos racionais e empregando formas legais para organizar as múltiplas ações e os múltiplos atores em múltiplas e variadas 
situações formais. A esfera pública convive com esses aparatos e com uma racionalidade que identifica neles o princípio de melhor eficiência profissional.

O Diário Oficial aparece, portanto, como o artefato central capaz de conectar e disseminar racionalidades: técnicas, legais, sistêmicas, profissionais, reunidas numa concepção de administração pública solidamente identificada com a razão legalista - os fundamentos e os respaldos formais, oficiais e assim legitimados -, formando o espírito da burocracia estatal.

O universo das publicações regulamentares, aqui pesquisado, representa a esfera dos atos do Poder Executivo paulista, focalizando a Secretaria Estadual encarregada da educação e seus órgãos centrais e vinculados. ${ }^{15}$ Entender a estrutura organizacional é primordial para nos situarmos diante do caráter das regulamentações que provém de cada órgão.

$\mathrm{Na}$ labiríntica organização burocrática estatal, as informações exclusivas da área educacional extraídas do Diário Oficial se referem à COGSP, órgão que coordena as ações educacionais nos municípios de São Paulo e da Grande São Paulo e no qual as escolas estudadas estão jurisdicionadas. ${ }^{16}$ Tendo em vista as dimensões assumidas por esse órgão central da Secretaria da Educação, o volume de regulamentações e decisões constatado surge como uma dinâmica esperável e proporcional à rede de unidades de ensino e ao contingente de profissionais contratados para atuar nessa rede. Quanto mais atores e instâncias se

\footnotetext{
${ }^{15}$ Até o primeiro semestre de 2011, a Secretaria de Estado da Educação de São Paulo (SEE) esteve organizada em sete órgãos centrais: Coordenadoria de Ensino do Interior (CEI), Coordenadoria de Ensino da Região Metropolitana da Grande São Paulo (COGSP), Coordenadoria de Estudos e Normas Pedagógicas (CENP), Departamento de Suprimento Escolar (DSE), Departamento de Recursos Humanos (DRHU), Centro de Referência em Educação (CRE) e Escola de Formação e Aperfeiçoamento de Professores (EFAP); e dois órgãos vinculados: Fundação para o Desenvolvimento da Educação (FDE) e Conselho Estadual de Educação (CEE). Em julho daquele ano, foi instituída uma reorganização da Secretaria, a qual, de acordo com o "novo modelo de gestão" noticiado no endereço eletrônico da Secretaria da Educação (SE), passa a ter seis órgãos compondo sua estrutura básica: Coordenadoria de Gestão da Educação Básica (CGEB), Coordenadoria de Informação, Monitoramento e Avaliação Educacional (CIMA), Coordenadoria de Infraestrutura e Serviços Escolares (CISE), Coordenadoria de Gestão de Recursos Humanos (CGRH), Coordenadoria de Orçamento e Finanças (COFI) e EFAP; e três órgãos colegiados: Comitê de Políticas Educacionais (CPE), CEE e FDE - cada qual abrindo um leque de departamentos, centros e núcleos (SECRETARIA DE ESTADO DA EDUCAÇÃO DE SÃO PAULO, 2011). Essas medidas e as diretivas que as acompanham foram instituídas pelo decreto $n^{\circ}$ 57.141, de 18/07/2011, publicado no Diário Oficial de 19/07/2011. Nesse ato está estabelecida a estrutura organizacional do sistema de ensino estatal sob novas chancelas, sem negligenciar as hierarquias (há um capítulo específico sobre quem se subordina a quem), configurando tarefas administrativas e determinando competências e atribuições.

${ }^{16}$ A COGSP possui sob sua jurisdição 2.266 unidades escolares (de um total de 5.444 instituições de ensino público em todo o Estado) abrangidas em 28 Diretorias de Ensino (são 15 Diretorias entre os municípios da Grande São Paulo e outras 13 Diretorias apenas no município de São Paulo, o qual concentra 1.134 escolas estaduais), o que representa o atendimento de mais de 2,7 milhões de alunos (COORDENADORIA DE ENSINO DA REGIÃO METROPOLITANA DA GRANDE SÃO PAULO, 2011). Em sua esfera de atuação está um contingente de 135.616 atores educacionais entre docentes, supervisores, diretores, dirigentes de ensino, coordenadores, secretários de escola, agentes de serviços escolares e de organização escolar (DEPARTAMENTO DE RECURSOS HUMANOS, 2011), o que equivale a $49 \%$ de todo o contingente da Secretaria da Educação - estrutura referente ao mês de julho de 2011. A organização institucional das escolas do interior paulista não foi pesquisada.
} 
entrelaçam no sistema educacional, mais atos administrativos são expedidos, compondo a trama de regularização de funções, adequação de procedimentos, decisões, contratações e novas formas de concatenar o quadro significativo de servidores. ${ }^{17}$

Encarregado da execução dos planos de governo para o âmbito educacional na região metropolitana de São Paulo, os instrumentos precípuos desse órgão são as portarias e os comunicados - documentos nos quais as prescrições e as decisões são divulgadas às escolas. Eventualmente, publicações conjuntas com outros órgãos centrais formam um coro uníssono em torno de questões que perpassam as atribuições, como, por exemplo, a implantação do currículo escolar e a admissão de novos docentes.

As publicações aqui sistematizadas envolvem ainda órgãos centrais como o DRHU, encarregado de administrar o contingente da Secretaria, expedindo instruções e diretrizes para movimentação e contratação de pessoal por meio de portarias; a CENP, cuja atribuição é emitir diretivas para o trabalho docente, publicadas na forma de instruções e portarias; além das resoluções - exclusivas do secretário de educação ou de seu gabinete -, por meio das quais ele "resolve" adotar procedimentos, padronizar medidas e decisões, e sistematizar prescrições e práticas que tenham sido decretadas.

No estudo e na coleta de informações publicadas no Diário Oficial, esses documentos regulamentares foram recolhidos e sistematizados de acordo com o que, nas edições, foi definido, classificado e publicado como portaria, comunicado ou resolução, e não de acordo com o conteúdo ou assunto abordado. A própria operacionalização das publicações nos orienta naquele sentido, já que cada uma delas está sistematicamente nomeada.

A operacionalização das publicações no Diário Oficial é realizada e centralizada pela Imprensa Oficial do Estado de São Paulo. De acordo com informações divulgadas pela própria empresa em seu endereço eletrônico, a publicação do Diário Oficial é sua principal atividade $;^{18}$ sua atribuição é fazer "publicar os atos oficiais do Estado [de São Paulo]". As denominadas "matérias" (os atos formais e legais) são transmitidas à Imprensa Oficial de cerca de seis mil pontos do Estado, por meio de um sistema eletrônico - "sistema pubnet" -, uma espécie de intranet para transmissão de dados. ${ }^{19}$ Esses pontos são os publicantes, os agentes ou instituições estatais autorizados a emitir, transmitir ou repassar regulamentos,

\footnotetext{
${ }^{17}$ Não temos condições de estabelecer parâmetros comparativos com outras Secretarias. O que nos interessa aqui é apontar o cenário nessa Secretaria.

${ }^{18}$ Segundo o site da empresa, são preparadas e impressas, diariamente, cerca de duas mil páginas para o Diário Oficial, o que "consome 450 quilômetros de papel todas as noites" (IMPRENSA OFICIAL DO ESTADO DE SÃO PAULO, 2011).

${ }^{19}$ A edição do Diário Oficial de 19/07/2011, Seção I, p. 4, traz um anúncio sobre esse sistema.
} 
comunicados e decisões oficiais, de todos os âmbitos da administração estadual, aí incluído o sistema de ensino.

A caracterização precedente compõe a descrição geral em relação ao volume de publicações que constatamos a partir de nossa aproximação ao Diário Oficial nos anos investigados. Na área educacional, o acerto e regularização das vidas funcionais ocupam parcela significativa daquele cenário de decisões. Classificados como portarias, tais documentos são emitidos unicamente como forma de tornar público um conjunto de concessões, ações e andamentos imputados a cada um dos servidores. As portarias, assinadas por diretores ou dirigentes de ensino, autorizam licenças, ratificam processos, regularizam regimentos escolares, tempo de serviço, e trâmites gerais da própria escola ou diretoria de ensino.

Parece claro que, como ressaltamos acima, a magnitude da publicação desses atos está diretamente relacionada ao número de servidores vinculados à pasta da Educação no Estado. No entanto, há outra parcela de documentos, igualmente significativa, que, a despeito de suas formas variáveis e até mesmo de suas origens díspares, se endereçam à instituição de ensino e ao cotidiano dos atores educacionais. Nos anos pesquisados, esses documentos e suas respectivas matérias, os "atos de governo", versaram sobre os temas a seguir.

- Decretos: instituindo o Programa Estadual de Desburocratização; dispondo sobre recadastramento dos servidores - matéria também de uma Resolução Conjunta da Secretaria da Fazenda (SF) e da Secretaria de Gestão Pública (SGP); regulamentando critérios para recebimento de bônus dos servidores e para concessão de bônus para docentes; criação de escolas técnicas; dispondo sobre o horário de trabalho dos servidores públicos e sobre o estágio probatório do magistério; criação do Banco de Informações sobre Pessoal; regulamentando o uso do celular nos estabelecimentos de ensino; dispondo sobre módulo de pessoal das unidades escolares; introduzindo medidas desburocratizantes na recepção de documentos; classificando e caracterizando unidades de ensino para concessão de Adicional de Local de Exercício; dispondo sobre órgãos do Sistema de Administração de Pessoal; instituindo o Sistema de Gestão Unificada de Administração de Recursos Humanos; dispondo sobre concursos, remoção e contratação de docentes; regulamentando a outorga de poderes aos Secretários.

- Instrução DRHU: procedimentos para servidores nomeados; dispondo sobre normas de preenchimento do livro de controle de frequência de docentes nas escolas da rede 
pública estadual (com manual de preenchimento e modelo); uniformização de procedimentos para posse e exercício.

- Portaria Conjunta DRHU/CENP: dispondo sobre atribuição de aulas.

- Portaria DRHU: estabelecendo diretrizes para atribuição de aulas; autorizando prorrogação de exercício para docentes; tornando públicas as normas para exames supletivos; disciplinando a concessão de adicionais financeiros aos salários; estabelecendo cronograma e diretrizes para atribuição de aulas.

- Instrução Conjunta COGSP/CEI/CENP/DRHU: dispõe sobre organização curricular e carga horária de aulas. ${ }^{20}$

- Portarias Conjuntas CENP/COGSP/CEI: convocações (para cursos ou reuniões).

- Resolução SE: instituindo o Sistema de Cadastro de Alunos; dispondo sobre o registro do Rendimento Escolar e sobre cadastramento de alunos; dispondo sobre a realização do Sistema de Avaliação do Rendimento Escolar do Estado de São Paulo (SARESP); dispondo sobre o horário de trabalho dos servidores nas unidades escolares; dispondo sobre o calendário escolar; diretrizes para a organização curricular; dispondo sobre a Consolidação das Leis e Normas Estaduais sobre o Ensino ${ }^{21}$; dispondo sobre estudos de recuperação; identificando unidades com Adicional de Local de Exercício; homologando a Deliberação do CEE que regulamentou a implantação do Ensino Fundamental de 9 anos; fixando o módulo de supervisor por Diretoria; procedimentos para substituição de servidores; revogação de outras Resoluções para "enxugar atos"; modelos e normas para o estágio probatório; instituindo o Índice de Desenvolvimento da Educação do Estado de São Paulo (IDESP); diretrizes para a organização curricular; dispondo sobre processo seletivo para atribuição e sobre o processo de

\footnotetext{
${ }^{20} \mathrm{O}$ objetivo explícito dessa Instrução era "orientar a equipe gestora da unidade escolar da rede estadual de ensino”. É preciso observar que essa Instrução Conjunta foi revogada por uma das Resoluções seguintes da Secretária de Educação à época, na qual ela desautorizou esse tipo de iniciativa sem antes ser aprovada por seu gabinete. Cf. Instrução Conjunta COGSP/CEI/CENP/DRHU, de 11-1-2007 e Resolução SE - 5, de 12-1-2007.

21 Reconhecendo uma proliferação de diplomas regulamentares, a Secretaria resolve "consolidá-los", "considerando: a necessidade de imprimir à gestão educacional maior racionalidade na aplicação da legislação de ensino às situações concretas; os trabalhos de compilação e atualização da legislação estadual de ensino fundamental e médio que vêm sendo desenvolvidos ao longo de várias décadas; os esforços do Governo do Estado de enxugar o acervo considerável de leis e decretos estaduais através de consolidação dos textos vigentes; o interesse desta secretaria de consolidar a legislação e normas afetas à Pasta da Educação, assegurando aos educadores melhor acesso aos textos legais e normativos em vigor". Cf. Resolução SE - 2, de 11-1-2008. Tal tarefa resultou no documento Unificação de Dispositivos Legais e Normativos relativos ao Ensino Fundamental e Médio - compêndio elaborado "após o exame de centenas de atos legais e normativos, compreendendo leis, decretos, resoluções SE e deliberações CEE", sistematizando "dispositivos legais e normativos que disciplinam e regulamentam a gestão curricular, pedagógica, de informação, de vida escolar, de pessoas, de patrimônio, de resultados, de recursos financeiros, de projetos e programas". Cf. SÃO PAULO (Estado), 2008, p. 07.
} 
atribuição em geral; normas para atender demanda; dispondo sobre implantação da Proposta Curricular; instituindo Núcleo de Pesquisa - Laboratório de Ideias. ${ }^{22}$

- Comunicados: concurso de remoção - classificação e vagas; aplicação de recursos na escola e prestação de contas; realização de "curso de atualização"; ${ }^{23}$ obrigatoriedade por parte das escolas de participar de avaliações; organização das Horas de Trabalho Pedagógico Coletivo (HTPC); dispondo sobre atividades bimestrais e a "obrigatoriedade do total cumprimento"; dispondo sobre reposição de aulas e pagamento.

- Resolução Casa Civil: orienta as Secretarias de Estado quanto aos procedimentos para contratação de pessoal.

- Instrução CENP: diretrizes e normas para implementação em São Paulo do Prêmio Nacional de Referência em Gestão Escolar; orientações sobre o Sistema de Avaliação de Rendimento Escolar.

- Instrução Unidade Central de Recursos Humanos (UCRH): dispondo sobre procedimentos relativos ao horário de trabalho e registro de ponto, com modelos de folha de ponto.

- Leis: proibindo o uso do celular nos estabelecimentos de ensino durante o horário de aula; obrigando as escolas a comunicarem o excesso de faltas de alunos.

- Leis Complementares: instituindo bonificação por resultados; dispondo sobre faltas médicas. $^{24}$

Esses assuntos e suas formas assumidas, propondo a gestão da educação pública, ajudam a compor o panorama sob o qual os indivíduos, no contexto escolar, estão atrelados mas não o esgota. Da mesma forma, a análise documental e a constatação da dinâmica regulamentar por meio do Diário Oficial contribuem para demonstrar um cenário de regulamentação, decisão, administração; no entanto, em termos legislativos e regulamentares, as prerrogativas podem assumir formas, conteúdos e dimensões difíceis de antever de um ano

\footnotetext{
${ }^{22}$ Esse núcleo foi constituído "considerando a necessidade do desenvolvimento de estudos técnicos que apóiem, direcionem e avaliem as ações de políticas educacionais". Cf. Resolução SE - 94, de 22-12-2008.

${ }^{23}$ Tendo como "objetivos: 1. motivar e sensibilizar a equipe, desde o líder até o corpo de trabalho, a caminhar para um objetivo comum; 2. propiciar reflexão e questionamento sobre sua forma de trabalhar e produzir, possibilitando a sedimentação dos pontos fortes e a reestruturação dos pontos fracos; 3 . subsidiar, uniformizar e consolidar procedimentos administrativos na condução das rotinas; 4. atualizar informações, propiciar estudos de casos e rever orientações quanto a: procedimentos com os processos (tramitação, despachos e organização); enquadramentos: Lei Complementar $\mathrm{n}^{\circ} 180 / 1978$ até a Lei Complementar $\mathrm{n}^{\circ}$ 247/1981". Cf. Comunicado DRHU-14, de 13-8-2007. Ganham destaque alguns termos e expressões como "objetivo comum", "reflexão", "questionamento", "sedimentação" - uma ideia de tornar firme. Além de ser um encontro para "consolidar procedimentos", a "atualização" ainda se concentra em peças regulamentares de um período autoritário, com intuito de organizar a ação em um período democrático.

${ }^{24}$ Esta Lei Complementar foi publicada três vezes "por ter saído com incorreções".
} 
ao outro. Isso se relaciona ao fato de que as pretensões dos membros da esfera estatal estão em constante movimento, são regularmente refeitas e, não raro, são concebidas novas formas de lidar com o imprevisto e o imprevisível, inaugurando meios - técnicos, sobretudo - de dispor mais eficientemente pessoas e coisas.

A relevância do arcabouço oficial está no fato de que ele utiliza instrumentos e racionalidades legais com o intuito de instituir procedimentos para uma burocracia profissional, identificando neles um princípio de produtividade e uso dos melhores meios para gerir as escolas públicas. Esse esquema parece encontrar robustez quando instruções, decretos, resoluções, portarias e leis propõem e estabelecem as formas e o conteúdo a ser ensinado; os horários de entrada e saída do serviço; o registro de ponto; os locais para assinaturas; os acessos e a manutenção das informações (por escrito ou por meio dos sistemas informatizados); o registro de faltas; as maneiras de abordar o público; o trato com a coisa pública; os vistos e os modelos a serem preenchidos; a atenção com os documentos válidos; a análise das qualificações e as exigências de boa saúde para os cargos; a forma de preencher diários, fazer relatórios, fichas individuais, ofícios, despachos e comunicados; as inúmeras prescrições que envolvem os acertos de vida funcional; as exigências a serem observadas para reforma das dependências, ocupação de zeladoria, atribuição de aulas; os prazos fixados para a realização da folha de pagamento de salários e vantagens pecuniárias; as maneiras fixadas para a execução de licenças; quando, onde e para quem entregar papéis e quem deve entregálos; os requisitos para avaliar a eficiência de docentes e funcionários; a atenção aos sistemas de avaliação; enfim, a ordenação de questões extensivas e perenes. As autorizações que muitas delas demandam implicam em tempos e percursos de maturação, próprios do serviço público, expressos numa documentação que vai, vem, carimba, assina, registra, volta e aguarda.

Como artefato com dinamismo próprio, o Diário Oficial é o portador de atos e formas de fazer - é um mediador, na concepção de Bruno Latour (1994) -, oferecendo campos e vínculos que fazem fazer. Por seus meios, ele autoriza, capacita e agrega as relações na escola. O Diário Oficial, nesse sentido, possui um estatuto muito específico: essa entidade não permanece em silêncio, como se não pudesse deixar de falar, visível, em destaque, o "tagarela perpétuo" (DEACON; PARKER, 1995, p. 107), o que consequentemente impele ao seu reconhecimento como uma entidade que se faz presente.

Na sociedade da técnica, o Diário Oficial é o paradigma de artefato sociotécnico. De fato, ele não é feito de matéria: está repleto de especialistas e legisladores que misturam suas vontades e perfis ao papel, tinta, computadores e cálculos. Os processos correlatos de 
modernização e gestão operacional que inaugura criam seu próprio contexto, mudam o contexto, redefinem o jogo, redistribuem a ordem dos seres e das coisas na esfera escolar. ${ }^{25}$

Nessa linha argumentativa, o Diário Oficial é o veículo para que instrumentos oficiais possam ser colocados em prática, mobilizando forças sociais. A realidade escolar é uma realidade compósita, na qual o jornal oficial coloca uma série de certezas oficiais que exigem inúmeras mediações na sua manutenção - o que contribui para amalgamar e instituir aquela realidade. Todo esse material não é um corpo sem vida - essa a razão das interações se prolongarem no tempo.

Os atos oficiais emitidos e as regulamentações sancionadas compõem, sob nosso ponto de vista, as estratégias de administração e organização do Estado, o que incide sobre uma racionalidade gestora de suas políticas públicas e sobre a burocracia encarregada dos assuntos públicos. É difícil crer, no entanto, que ele possa controlar os processos que desencadeia de forma absoluta. Nele, antes, há um emaranhado de pretensões para dispor de forma eficaz e para limitar as probabilidades de erro ou de desvio.

$\mathrm{O}$ conjunto de atos e regras que tivemos contato moveu-se pela preeminência de estabelecer, para as instituições públicas, para os interesses e temas estatais, tanto rigor ordenativo quanto possível. Nesse objetivo, proporção substantiva de decretos no período estudado dispôs sobre: autorização para receber áreas ou imóveis de municípios, declaração de utilidade pública para entidades; abertura de crédito suplementar para Secretarias e Autarquias; regulamentação sobre símbolos estaduais e definição da porcentagem de cores (também matéria de Resolução). Dentre os assuntos abordados pela legislação no período, também se destacam leis editadas para revogar outras leis e resoluções entre os anos de 1835 e 1890; para dar denominações às praças, viadutos, ruas e avenidas; dispondo sobre o registro de estabelecimentos de fundição de joias, além do controle de natalidade de cães e gatos.

Tais marcos regulatórios também ajudam a compor um amplo espectro de artes governamentais a serem concretizadas, levadas em consideração diante das correlações de força no âmbito político. Elas estão promovendo procedimentos e deslegitimando outros, estabelecendo uma racionalidade funcional que pretende ser permanente no suporte de regularidades.

As regularidades que assim se esboçam ganham seus espaços no Diário Oficial. Vimos acima os cadernos ou seções do Poder Executivo tornando públicas formas esquadrinhadas para produzir e dispor de mais e melhores meios. No entanto, elas não se restringem àquelas

\footnotetext{
${ }^{25}$ Considerações elaboradas a partir da fértil discussão contida em Latour, B. Jamais Fomos Modernos. São Paulo: Editora 34, 1994.
} 
seções. O caderno Suplemento, também da esfera do Poder Executivo, possui como características a publicação de atos e decisões complementares àquelas já publicadas, e de regulamentos que, principalmente devido a sua extensão, não fizeram parte das edições rotineiras. Também é característica desse caderno a emissão de diretivas acertadas em caráter extraordinário, tendo sido tomadas após as edições regulares já estarem encerradas e preparadas para publicação.

Os assuntos publicados em cada uma das edições do caderno Suplemento são monotemáticos. Essa área do Diário Oficial concentra, geralmente, listagens. São páginas e páginas, listas e listas que, entre 2007 e 2008, receberam a publicação dos seguintes documentos: leis de orçamento e despesa do Estado para 2007, 2008 e $2009^{26}$; lei instituindo o Plano Plurianual para o quadriênio 2008/2011; Cadastro de Reclamações Fundamentadas da Fundação de Proteção e Defesa do Consumidor (Procon-SP); relação de cargos e funções das Secretarias; relação de aprovados e classificados em concurso público de diretor de escola; resolução da Secretaria da Educação relacionando as escolas integrantes da rede pública; classificação geral, relação de vagas e relação dos contemplados em concurso de remoção de docentes; relação de contribuintes em débito com o Imposto sobre a Propriedade de Veículos Automotores (IPVA) - notificações publicadas pela Administração Tributária da Secretaria da Fazenda; resolução da Secretaria da Fazenda fixando os valores venais de veículos usados para cálculo do IPVA; classificação e relação de vagas para concurso de remoção do Quadro de Apoio Escolar; relação de cargos e funções de direção e chefia com indicação de seus substitutos; classificação geral para processo seletivo regional de Agente de Serviços Escolares e Agente de Organização Escolar; classificação geral dos docentes para o processo seletivo de atribuição de classes e aulas; lista de inscrições e classificação para estágio no setor público e para participação no Programa Acessa Escola; e relação de aprovados em concurso público para supervisor de ensino.

Ao todo, 36 edições desse tipo foram publicadas, ocupando quase 15 mil páginas. Ganhou destaque a promulgação de leis basilares e de grande vulto ${ }^{27}$; as extensas e constantemente atualizadas relações de contribuintes em débito com o IPVA - publicadas sete vezes e totalizando mais de 10 mil páginas; além de todas as listagens gerais, como a relação de cargos de direção e chefia. Em relação a esta última, 57\% da edição na qual foi publicada

\footnotetext{
${ }^{26}$ Cabe observar que a maior previsão de gastos para 2008 esteve relacionada à Secretaria da Educação, com uma cifra de mais de R \$ 13 bilhões, seguida pela Secretaria de Segurança Pública, com mais de R \$ 8 bilhões; para 2009, as maiores previsões continuaram com essas Secretarias: mais de R\$ 15 bilhões para a Educação e mais de R \$ 10 bilhões para a Segurança Pública.

${ }^{27}$ Apenas uma delas, a que orçou a receita e a despesa para 2009, ocupou 288 páginas.
} 
se referiam a cargos na área da educação pública estadual. As relações, listagens e diretrizes da Educação ocuparam 15 edições, o equivalente a $42 \%$ de todas as edições publicadas no caderno Suplemento. Neste, inclusive, houve certa predileção por publicar tais diretivas nos finais de semana: $45 \%$ de todas as edições foram publicadas aos sábados.

Conforme é possível avançar no desbravamento do Diário Oficial, mais amplo se torna o panorama da racionalidade administrativa e legal no escopo dos setores públicos. As relações elaboradas e centralizadas no Estado conquistam um estatuto de práticas “governamentalizadas", disseminadas e direcionadas como potências eficientes e produtivas na trama pública. No interior de tais práticas estão em jogo os avanços, as metas, as prioridades, a profissionalização, as motivações e os embates, esquemas acionados e enredados na estratégia estatal. Podemos vislumbrá-la em uma das exposições publicadas no próprio Diário Oficial:

[...] a SEE vem colocando em prática as novas propostas da atual gestão voltadas à autoavaliação e avaliação externa, como meios de correção e estratégia para melhoria dos indicadores de aprendizagem através de sistemas externos de avaliação. [...] Para a Secretaria da Educação tão importante quanto manter conquistas como a universalização do acesso à Educação é propiciar condições para um salto qualitativo no resultado da aprendizagem, ainda que consideradas as dimensões da maior rede pública de ensino da América Latina, com 5,5 mil escolas, 240 mil professores e 5 milhões de alunos. [...] A educação é estratégia, para o desenvolvimento humano, social e econômico de São Paulo e do Brasil. Daí o compromisso deste Governo com a qualidade do ensino, ferramenta fundamental para os avanços que pretendemos para a sociedade. Universalizar o ensino fundamental e o acesso ao ensino médio são metas a serem continuamente perseguidas. Investir na motivação e profissionalização do docente; fortalecer a escola, garantindo autonomia, a capacidade de gestão e as condições físicas; investir na sua autoavaliação, na avaliação externa como meio de correção de estratégias para a melhoria dos indicadores de aprendizagem; assegurar assistência técnica aos municípios mais pobres, estão entre as principais ações do Governo do Estado voltadas ao aprimoramento do ensino. ${ }^{28}$

\footnotetext{
${ }^{28}$ Esses comentários fazem parte da Resolução s/n, de 30-12-2008, homologando a Deliberação CEE 81/2008 que aprovou o Plano de Aplicação de Recursos da Secretaria de Educação. Os trechos citados foram extraídos do item "Diagnóstico".
} 
As oportunidades de exercitar as artes de dispor o sistema de ensino transformam práticas em especializações e integrantes em especialistas na gestão de pessoas e aparatos, técnicas e recursos. A riqueza de exposições como as citadas acima evidenciam posicionamentos oficiais diante de estruturas estatais, em termos, sobretudo, de estratégias: utilizar a racionalidade legalista, manipular técnicas, dispor de meios, disseminar princípios de administração e gestão, compor, com instrumentos regulares, oficiais e legítimos, maneiras de lidar com os cotidianos a serem administrados. Leis, resoluções, portarias, decretos são, como procuramos explorar, documentos dessa trama.

A oficialidade de discursos e justificativas estatais presentes no Diário Oficial não se limitam, contudo, aos textos legais sancionados. Encontramos essas mesmas exposições em instrumentos que negam a disseminação de determinadas decisões e atos regulamentares - os vetos. Geralmente, a justificativa para os vetos esteve concentrada na alegação de ingerência do Legislativo em assuntos de exclusiva "decisão administrativa e verdadeiro ato de gestão" do Executivo, inclusive sem a análise do mérito da matéria em si. Também aqui, nos vetos, os integrantes do círculo decisório lançam mão de suas estratégias complementares: manipulam e interpretam regulamentos para barrar "tudo o que não seja espelho", tudo o que não esteja de acordo com a visão gestora mais apropriada e fortemente associada ao conjunto de suas competências oficiais.

A mesma alegação de ingerência é usada no CEE para reprimir, criticar, desqualificar, desconstruir, anular, postergar e esmiuçar até subsumir as recomendações e pareceres do Conselho Nacional de Educação (CNE) - sempre tendo como guardião de suas razões o "pacto federativo", mobilizando toda a estrutura legal asseguradora daquele "pacto" para combater o que frequentemente é classificado como "ingerência no regime jurídico dos entes federados, em desrespeito à organização federativa do Estado Brasileiro", ${ }^{29}$

Em suas manifestações discursivas, publicadas e republicadas diariamente, o Diário Oficial oferece não apenas o arcabouço legal, os regulamentos de toda ordem, as formas de administrar e se relacionar com as instituições estatais, uma racionalidade administrativa em torno do legal e do oficial, mas também uma visão de gestão, justificativas para as decisões, razões para a atuação e manutenção da estrutura ordenativa e dos imperativos instituídos tudo isso sendo mobilizado conjuntamente e incrementado por aquela racionalidade legalista.

Ao mesmo tempo, podemos observar, pela leitura do Diário Oficial, os combates que se estabelecem em torno daquela racionalidade, as disputas e lutas para estabelecer

\footnotetext{
${ }^{29}$ A íntegra do parecer pode ser encontrada no Comunicado s/n do CEE de 12 de novembro de 2008, publicado no Diário Oficial em 26 de novembro de 2008.
} 
prerrogativas, lutas inclusive entre instâncias de governo, procurando, cada qual, não estar jamais tutelada - o que envolve, evidentemente, disputas político-partidárias. As autênticas “exposições de motivos" contidas em suas páginas terminam por indicar e demonstrar que o ordenamento estadual é uma construção permanente; longe de ser harmoniosa, é marcada pelo signo da divergência e levada adiante por uma batalha na qual os instrumentos jurídicos auxiliam a constituir suas forças, seus elementos e seus alicerces fundamentais.

\subsection{A legalização como estratégia estatal}

As considerações precedentes procuraram evidenciar as formas, os conteúdos e os discursos oficiais presentes nos regulamentos. Abordados de maneira conjunta, representam uma racionalidade, uma concepção de público, uma estratégia. Eminentemente ligada aos aspectos formais, a racionalidade que demonstram pugna pela legalidade e pela legitimidade, pelo zelo no trato com as instituições públicas, pela caução legal - nesse sentido, uma racionalidade legalista.

O levantamento realizado demonstrou amplo leque na produção legislativa, caracterizada por intercruzamentos de discursos e esforços para consolidar regulamentos, para formar ou "atualizar" mentalidades que orbitem o procedimentalismo oficial, próprio do que seria a maneira mais racional de constituir a série de ordenamentos diante de instituições públicas e planos estatais. Nessa perspectiva, pode ser um desafio transitar por esse emaranhado, visto por Soares (2004, p. 293, grifo da autora) como uma "árdua tarefa de desultar o cipoal normativo brasileiro considerando a 'vocação legiferante' de nossos governantes somada a uma estrutura federativa".

O Estado, de fato, possui essa necessidade de legalidade. O esquema que assim é traçado no presente não apenas se torna fundamental em relação às formalidades burocráticas que garantem a manutenção do ordenamento escolar, como também em relação à própria salvaguarda dos direitos individuais e coletivos, baseando-se nas prerrogativas colocadas pelo aparato legal, inclusive como forma de estabelecer limites à razão de Estado. A lei, como princípio, é o reino da ausência de injustiças e de favorecimentos, a crença no tratamento igualitário e generalizável, a crença de que a própria coletividade é guardiã da justeza daquelas ações e é ilegítimo permitir que seja realizado qualquer ato que lhe esteja em desacordo. Plenamente identificada com o Estado democrático de direito, em que ele não se processa sem aquele princípio, a lei é o aparato socialmente construído e socialmente aceito, 
único reconhecido e autorizado a dispor pessoas e coisas, de maneira que ele apareça como indispensável à organização dos indivíduos, das coisas e das instituições.

O discurso que é constituído como legal define a validade das regras. Inseridas no processo de administração, elas legitimam ações e princípios, reativam outros, corrigem sua aplicabilidade. Diante de funções a serem preenchidas, oferecem características que lhe são próprias, disseminando competências e técnicas apropriadas. O "jurisdicionamento" estabelecido propõe, de acordo com Foucault (1985, p. 185), não apenas "demarcar o permitido e o proibido, mas sim uma maneira de ser, um estilo de relações".

É possível afirmar, com certa margem de veracidade, que há instrumentos jurídicos elaborados e não aplicados; no entanto, enquanto inauguram formas de se relacionarem com objetos, objetivos e seres humanos, portam graus de aplicabilidade, os quais não podem conceber ou disseminar maneiras, estilos e princípios organizativos sem um elemento que implique em constrangimento aos indivíduos. Assim, demonstram uma conotação imperativa, ameaçadora, traduzível na mística "força de lei” (DERRIDA, 2010, p. 102), de áurea vigilante, espectral, sem rosto, que satura o espaço público e contribui para instituir o fundamento da autoridade.

Todo esse “jurisdicismo", essa organização jurídico-estatal, perpassa a estrutura administrativa, institucional e burocrática. Por esse motivo, não podemos supor que os regulamentos não tenham sua importância para os trâmites oficiais. É sempre possível dar maior ou menor ênfase à dimensão regulamentar; entretanto, seu caráter de estratégia estatal é essencial perante os interesses políticos em jogo e no interior de instituições públicas onde esse jogo acontece.

Em tal perspectiva, a escola pública se apresenta como uma dessas instituições, na qual as técnicas legais e oficiais são colocadas para lidar com seus temas intrínsecos, sua estrutura humana, seus formulários, fichas, arquivos, suas regularidades e irregularidades. As unidades de ensino estão inseridas nessa trama cotidiana, convivendo com princípios elementares distribuídos por atividades diversas (pagamentos, afastamentos, licenças, faltas, notas de alunos, transferências, nomeações, aposentadorias, registro de frequência, adicionais, relatórios, ofícios, processos e regularizações).

O corpo político estatal, com suas técnicas e procedimentos apoiados pela instrumentalização jurídica, é caracterizado pelo procedimentalismo de seus órgãos e sistemas administrativos, convertendo em rotinas o complexo emaranhado de regulamentações. Estas últimas são, nas palavras de Foucault (2005, p. 236), "não resultados definitivos, mas táticas que se deslocam", uma vez que estão constantemente refazendo seus objetivos, assumindo 
novas formas e novas prerrogativas em virtude de conflitos, atritos e ilegalidades. Inseridas no ordenamento institucional público, tais táticas podem ser classificadas como "táticas gerais da governamentalidade" (FOUCAULT, 1979, p. 289).

O elenco de medidas administrativas, assim, compõe uma estratégia, mas não asseguram o caráter de algo justo. $\mathrm{O}$ reino da justiça extrapola a esfera regulamentar, diante do qual as regras se tornam sombras, evenescências que pairam pelas instituições. As regras legais garantem um ordenamento específico, uma tática gestora, uma estratégia administrativa, não o limiar entre o que pode ser considerado justo ou injusto. Como aponta Derrida (2010, p. 30), “cada vez que as coisas acontecem ou acontecem de modo adequado, cada vez que se aplica tranquilamente uma boa regra [...] o direito é respeitado, mas não podemos ter certeza de que a justiça o foi”. Em certa medida, os instrumentos jurídicos tentam garantir a justeza dos fins para os quais são mobilizados valendo-se da legitimidade dos próprios meios legais.

Estratégia no interior de estratégias, portanto; tramas e táticas enredadas e instauradas para conservarem-se a si mesmas e conservarem-se como potência. Subjacente a sua dinâmica está a exclusão da desordem, de tudo o que não reconhecem como sendo suas convenções válidas e legitimadas para administrar os contextos públicos. Com essa perspectiva, podemos compreender que:

O poder faz do direito o instrumento da sua apresentação de modo a reservar o segredo que lhe é essencial. [...] lei como modo de expressão, [...] interdição e a sanção como mecanismos. Deste modo, o jurídico não foi [...] apenas a forma da sua aceitabilidade [do poder], mas também a sua "linguagem", o seu "modo de manifestação", o seu "código" (EWALD, 2000, p. 121).

O direito é a linguagem adotada e a apresentação concebida para o exercício do poder. No campo legal que o constitui, confunde-se, frequentemente, o necessário com o facultativo, o inútil com o definitivo, aspectos que, "a partir do simples desvio fazem pesar cada vez mais a regra" (FOUCAULT, 2005, p. 247). A regra legal anseia por atividades articuladas, pelo exercício ordenado, e termina por assumir a forma de exigências insistentes, organizadas como instrumento de disposição contínua, situação na qual "uma pancada distraidamente dada em uma porta desencadeia processos incontroláveis” (AGAMBEN, 2010, p. 58), podendo significar a reafirmação do regulamento e a sanção pelo desvio.

Desvios ou portas que não são fechadas cuidadosamente são indícios de que, como aponta Derrida (2010, p. 91), “a transgressão está diante da lei”. O imprevisível, o 
inconcebível, o não planejado e o subitamente inesperado podem surgir, mesmo com todos aqueles instrumentos jurídicos apontados, disseminados e inseridos na estrutura administrativa, visando estabelecer liames seguros em sua organização. No extremo dessa noção, a ilegalidade é passível de surgimento, a ação não autorizada, não legitimada, a extrapolação daqueles liames. Para Derrida (2010, p. 80), “o Estado suporta mal essa passagem do limite". Em seu julgamento, ele a desqualificará, a tornará abusiva, "ilegal", ilegítima, injustificada, passível de punição em nome da preservação das formas legais constituídas e da manutenção do ordenamento administrativo, de sua racionalidade estratégica.

No contexto traçado, o Estado utiliza os instrumentos jurídicos de maneira incremental: o direito como meio, a intricada manipulação das leis, decretos, resoluções e demais aparatos regulamentares como mecanismos para propiciar atuações, soluções, ordenamentos e reordenamentos. Tal estratégia contribui para estimular a proliferação dos dispositivos legais e medidas administrativas. Partindo dessa pretensão instrumental, podemos vislumbrar que "a função legislativa foi alçada como a mais importante, dentre as demais, no Estado moderno" (SOARES, 2004, p. 137).

A multiplicidade e a variabilidade de regras assumem a forma de uma rede, entrelaçando-se para regularem matérias, num autêntico movimento de "espraiamento" institucional. Nessa perspectiva e de acordo com Ewald (2000, p. 121), "a proliferação contemporânea de instrumentos 'jurídicos' [os códigos, constituições e leis], o fato de o moderno exercício do poder ser acompanhado pela respectiva inflação seria a máscara de um poder que funciona de acordo com o regime da norma".

É possível afirmar, a partir da perspectiva foucaultiana, que o sistema que se descortina não está apenas na lei, mas na normalização - um conjunto de ações, conceitos, estatutos, ideias, formas materializáveis, que podem atravessar com maior ou menor intensidade os instrumentos do direito e constituir a difusão de "um saber que [...] se ordena em torno da norma, em termos do que é normal ou não, correto ou não, do que se deve ou não fazer" (FOUCAULT, 1974, p. 70).

No plano político-estatal, o jogo que se repete diariamente nas instituições públicas, inclusive as de ensino, orbita essa difusão de procedimentos "normais", identificados e legitimados como norma e padrão funcional, amalgamados à organização dos serviços e ao desempenho das funções. Os regulamentos legais, dessa forma, são concebidos e impregnados pela norma, pelas posições e oposições entre normal, anormal, patológico, por aquilo que é identificado como correto e incorreto. Portadora de noções ligadas ao "normal", "a lei 
também pode funcionar como uma norma, formulá-la, e ser assim uma das peças [do] poder [...]” (EWALD, 2000, p. 78).

A formação e disseminação de instrumentos normalizadores, capazes de especificar, simplificar e unificar atividades, estão em paralelo com uma proliferação legislativa que remete regras a outras regras preexistentes, criando um círculo de valores normativos. Impregnação normativa simultaneamente a uma inflação legislativa. A estabilidade que alcançam não impede que ocorram variabilidades, limitações, anulações. Diante de tais "contratempos", diante do fracasso administrativo, mais administração é concebida; o fracasso das leis ou dos decretos resulta em mais leis e decretos, na tentativa de reinstaurar a administração ordenada, a racionalidade legal e legítima, os procedimentos "normais", a ordem normativa.

Estamos diante de um cenário de "generalização da normalização" (DEACON; PARKER, 1995, p. 105), uma ciência da regulamentação configurando intervenções refinadas, tecnologias e conhecimento aprimorado, ampliando as esferas de regulamentação e promovendo um "espraiamento" de racionalidades legais e administrativas pelas instituições públicas.

Publicado no Diário Oficial de 19/07/2011, o decreto nº 57.141 de 18/07/2011 (citado anteriormente a respeito da reorganização administrativa do ensino) ${ }^{30}$ constitui um dos instrumentos legais de ampla esfera de regulamentação, contemplando decisões, competências, estruturas, características, formas, diretivas, temas relacionados - elementos por meio dos quais é afirmada e reafirmada uma racionalidade administrativa que procura consolidar a eficiência de esquemas no sistema de ensino público, compondo um programa normativo, uma série uníssona em relação ao "normal”, ao padrão para melhor gerir, ao princípio ordenativo.

Trata-se de noções, modos de organização, concepções e artes burocratizadas expressas da seguinte forma:

As atribuições da Secretaria da Educação serão exercidas com forte articulação entre as unidades da estrutura [para assegurar] a orientação técnica e normativa emanada das unidades centrais [artigo 26]; elaborar propagandas [a partir de] padrões [artigo 31]; instituir Grupo de Legislação Educacional [artigo 35]; instituir Centro de Legislação de

\footnotetext{
${ }^{30}$ Este decreto, ao reorganizar toda a estrutura do sistema de ensino público, exige uma série de decisões a serem refinadas e complementadas por outros instrumentos oficiais, como resoluções e portarias, transformando o "grande esquema" num plano de continuidade que atinja toda a rede entrelaçada, detalhando competências. Este decreto foi estruturado em 132 artigos e ocupou nove páginas no Diário Oficial.
} 
Pessoal e Normatização [artigo 62]; dispor de informações e técnicas e monitorar as ações realizadas [por meio do] Departamento de Informação e Monitoramento [artigo 51]; receber, registrar, protocolar, classificar, autuar, expedir e controlar [...] papéis e processos [artigos 36 e 76]; especificar padrões [...] propor a definição de padrões [artigo 53]; os supervisores de ensino [devem] exercer [...] a fiscalização das escolas [...] para aprimoramento da gestão escolar [...] [acompanhar] ações desenvolvidas nas horas de trabalho pedagógico coletivo - HTPC [e] a atuação do Conselho de Classe e Série, analisando os temas tratados e o encaminhamento dado às situações e às decisões adotadas [artigo 72]; prestar assessoria aos agentes escolares no cumprimento dos textos legais [...], orientar [...] os responsáveis pelos estabelecimentos de ensino quanto ao cumprimento das normas legais e das determinações emanadas das autoridades superiores [e] orientar os professores para garantir a implementação do currículo [artigo 73]; [cabe aos] Centros de Recursos Humanos controlar as rotinas de administração de pessoal [artigo 75]; [aos] responsáveis pela Articulação Regional da Secretaria da Educação compete fazer observar a regularidade dos serviços, expedindo as necessárias determinações [artigo 83]; às Diretorias de Ensino [...] supervisionar, orientar e acompanhar o funcionamento das escolas [...] no cumprimento das políticas, diretrizes e [...] para o atendimento das metas da Secretaria [de forma a] garantir unidade e convergência na orientação às escolas [artigo 70]; fazer cumprir instruções elou orientações normativas referentes [...] à uniformização de práticas e procedimentos [artigo 32]; fazer cumprir atos e decisões administrativas [artigo 40]; cumprir e fazer cumprir as leis, os regulamentos e as decisões das autoridades superiores [...] de acordo com a política e as diretrizes fixadas pelo Governador [artigo 80]; [cabe ao secretário] expedir atos e instruções para a boa execução dos preceitos [...], das leis e dos regulamentos [artigo 81]; [compete aos chefes de seção, dirigentes de unidades, dirigentes de ensino e aos diretores de escola] cumprir e fazer cumprir as leis, os decretos, os regulamentos, as decisões, os prazos para desenvolvimento dos trabalhos e as ordens das autoridades superiores; [...] transmitir a seus subordinados as diretrizes a serem adotadas no desenvolvimento dos trabalhos; [...] manter seus superiores imediatos permanentemente informados sobre o andamento das atividades das unidades ou dos servidores subordinados [...] zelar pela regularidade dos serviços, expedindo as necessárias determinações ou 
representando às autoridades superiores [artigo 106]; [instalar] canais de comunicação em rede para veiculação de informações e orientações [artigo $122]$.

As maneiras de conceber a administração pública reverberam, como é possível notar, nas próprias terminologias empregadas, nos usos dos verbos e na construção textual. Esse conjunto de regras forma um conjunto de investimentos de efetivação: investimentos para articular, obter informações, disseminar técnicas, monitorar, padronizar, orientar, estabelecer convergência, harmonizar, garantir serviços ininterruptos, uniformizar práticas. Para Ewald (2000, p. 52), "trata-se de dispor espaços, constituir células, de quadricular, de ordenar, de definir empregos do tempo, de os acumular, de os programar, de os compor de acordo com exercícios, manobras e táticas". Nesse sentido, autêntico ato normativo, identificando diretrizes eficientes, bem assentadas e "normais" em torno de padrões e noções administrativas. Ao publicar atos como esse, o aparelho estatal oferece visibilidade a um modelo racional de gerir e buscar resultados, implementando-o como essência organizacional do serviço público no âmbito da estrutura educacional.

No cenário de regulamentação institucionalizada, os traços ganham contornos imperativos e sistemáticos. Utilizando mecanismos linguísticos, jurídicos e técnicos, a instrumentalização jurídica porta uma racionalidade intencional, premeditada e normativa, de caráter necessário. Certamente, como evidencia Ewald (2000, p. 118), "uma economia normativa das obrigações admite todos os graus de constrangimento". Dessa forma, a organização institucional se torna o reino do "adequado", do "compromisso", do "útil calculado", considerando a melhor forma de "conduzir condutas" e dispor, governar, “estruturar o eventual campo de ação dos outros” (FOUCAULT, 1995, p. 244).

Os aspectos apresentados acima indicam a composição de uma racionalidade legalista que mobiliza noções normativas para constituir uma gestão operacional na esfera pública, a qual é traduzida por procedimentos que são incessantemente antecipados, acompanhados e ordenados. De acordo com Rancière (1996, p. 113):

A extensão desse processo é a crescente identificação do real com o racional, do jurídico com o científico, do direito com um sistema de garantias que são acima de tudo as garantias do poder do Estado, a garantia sempre reforçada de sua infalibilidade, da impossibilidade de que seja injusto, a não ser por erro, um erro do qual ele não cessa de garantir-se mediante a consulta incessante de peritos sobre a [...] legitimidade do que faz. Há então uma 
conjunção entre três fenômenos: a juridicização proliferante, as práticas de perícia generalizada e as da sondagem permanente.

A discussão precedente vislumbrou o panorama de uma racionalidade legal, de caráter normativo, impregnada na administração pública. Nas considerações em torno da dinâmica de publicações no Diário Oficial, foi possível constatar que, de fato e de direito, pode-se ter tantas leis e tantas regulamentações quantas se quiser. No entanto, como nos lembra Ewald (2000, p. 120), “se em direito tudo é [...] possível, na prática os possíveis são predeterminados e pouco numerosos". A partir das ações cotidianas, é nosso propósito explorar, precisamente, essa prática - entre limitações e possibilidades -, os discursos e debates acionados, as perspectivas e as relações estabelecidas com os instrumentos regulamentares. Trata-se, agora, de observar as estratégias desencadeadas pelos atores diante daquela racionalidade legalista o que implica examinar os posicionamentos dos sujeitos perante regras legais, as diferenciações e nuances produzidas nas instituições escolares. 


\section{CAPÍTULO 2 \\ REGRAS E PRÁTICA COTIDIANA: RELATO SOBRE AS ATIVIDADES E EXPERIÊNCIAS NO CONTEXTO ESCOLAR}

[...] agentes são soberanos na medida em que reivindicam e defendem com sucesso o direito de gerenciar e administrar a existência.

Bauman, 1999

Determinadas coisas sempre nos escapam, e o que nos escapa é produto de nossa posição no tecido social, de nossos pontos de vista. Na tentativa de superar nossas limitações para avaliar determinados aspectos, empreendemos um deslocamento de posição, comparecendo perante instâncias de ensino com o intuito de evidenciar os efeitos daqueles instrumentos legais e atos oficiais sobre as práticas - conscientes de que toda e qualquer análise que resulta do trabalho de pesquisa é sempre um ponto de vista, o qual se, por um lado, permite a análise detalhada e profunda de determinados aspectos da vida social, deixa, por outro, escapar dimensões que permanecem fora do "campo de visão".

A forma de abordagem adotada aqui esteve voltada para apresentar precisamente as características das situações encontradas nas escolas. Empreendemos observações sistemáticas das ações nos âmbitos institucionais investigados; buscamos a observação como descrição etnográfica das formas e dos sentidos que os indivíduos demonstram, levando em consideração os condicionantes e contextos, assim como as condições concretas de trabalho.

Procuramos explorar as relações entre os aspectos legais e suas conexões e desconexões com o cotidiano, mostrando o que está acontecendo nas escolas, as práticas fundadas, as maneiras como a legislação é encarada, as relações operadas entre a prática e a racionalidade formal-legal, as mediações entre o legal e o ilegal.

Os instrumentos e perspectivas mobilizadas no estudo da escola compõem os esforços para conseguir compreender e descrever as situações, revelar seus múltiplos significados, as relações e tensões na experiência escolar, buscando iluminar algumas posições assumidas sem a pretensão de esgotá-las - no emaranhado de condições institucionais, objetividades e subjetividades.

A aproximação às unidades escolares ocorreu no final do segundo semestre de 2011 período no qual também foram realizados os acompanhamentos e investigações. Optamos por 
dois estabelecimentos de ensino como os terrenos de nossas considerações: uma escola estadual localizada no município de Carapicuíba ${ }^{31}$ (doravante denominada 'escola C'), região periférica da Grande São Paulo, e uma escola estadual localizada na região central do município de Osasco ${ }^{32}$ (doravante denominada 'escola O'), também na Grande São Paulo. ${ }^{33}$

No contato institucional, foi possível conversar pessoalmente com as diretoras das escolas sobre os objetivos da pesquisa. As tratativas foram bastante positivas e ao final recebemos a autorização para acompanhar as reuniões de HTPC e as reuniões do Conselho de Classe referentes ao encerramento do ano letivo. Ao todo foram acompanhadas doze reuniões de HTPC entre os meses de setembro e novembro, e oito reuniões do Conselho de Classe durante os meses de novembro e dezembro. Como as datas e os horários coincidiam em ambas as escolas, adotamos um "revezamento", comparecendo a uma unidade num período e à outra no período seguinte - já que as reuniões aconteciam no mesmo dia. Para o Conselho de Classe, optamos em acompanhar as reuniões numa única escola, como forma de não

\footnotetext{
${ }^{31}$ A escola visitada está jurisdicionada à Diretoria de Ensino de Carapicuíba, a qual abrange os municípios de Carapicuíba e Cotia. De acordo com informações da própria Secretaria da Educação, disponibilizadas em seu portal eletrônico, o município de Carapicuíba possui 57 escolas estaduais. Essa Diretoria possui ao todo 86 escolas e um contingente de 5.372 atores entre docentes, supervisores, diretores, coordenadores e funcionários administrativos. Segundo dados do IDESP, que "avalia a qualidade das escolas estaduais", a escola observada apresentou em 2010 um índice de "cumprimento de metas" em torno dos 2,0 (dois) pontos, em média, indicando desempenho acima do esperado no período avaliado (SECRETARIA DE ESTADO DA EDUCAÇÃO DE SÃO PAULO, 2011).

${ }^{32}$ A escola está atrelada à Diretoria de Ensino de Osasco, na qual estão jurisdicionadas 58 escolas - o que representa um contingente de 3.907 servidores (DEPARTAMENTO DE RECURSOS HUMANOS, 2011). Dados do IDESP para 2010 apontam que a unidade escolar está entre as de melhor desempenho na região, com indicadores acima dos 3,0 (três) pontos. Escolas como esta demonstram, de início, índices tão significativos (o que seria a expressão de seu desempenho excepcional) que torna difícil atingir as metas estipuladas pela Secretaria, traduzidas por indicadores mais elevados ainda. Podemos notar que as diferenças entre as duas escolas observadas, em termos numéricos, não parecem ser significativas. No entanto, é preciso atentar que, na escala construída, diferenças decimais nos resultados indicam mudanças significativas de desempenho.

${ }^{33}$ Extrapola nossos objetivos discutir aqui os usos dos termos "centro" e "periferia". Entretanto, cabe destacar que adotamos a noção de periférico como uma dimensão socioespacial marcada por carências, caracterizada pelo espaço de entorno, que possui o centro como referência. Ambos (centro e periferia) são dotados de encontros públicos, de atores e sociabilidades, que interagem com instituições e equipamentos urbanos que lhes são específicos e de forma específica, produzindo contextos sociais distintos com ações e resultados díspares. O perfil municipal, de acordo com o Índice Paulista de Responsabilidade Social (IPRS) da Fundação Sistema Estadual de Análise de Dados (SEADE), indica que Carapicuíba faz parte do grupo 4, o qual engloba os municípios com baixos níveis de riqueza e indicadores sociais intermediários. Incorporado ao IPRS está o Índice Paulista de Vulnerabilidade Social (IPVS), o qual indica que apenas 37\% da população do município não possui nenhuma vulnerabilidade à pobreza ou ela é baixa (o que significa melhor situação socioeconômica). Ainda de acordo com os dados da Fundação SEADE, Osasco está classificado no primeiro grupo do IPRS, no qual estão englobados os municípios mais bem posicionados em termos de riqueza e indicadores sociais. A mesma tendência é apontada pelo IPVS, o qual indica que 55\% da população do município não possui vulnerabilidade socioeconômica. Segundo os critérios adotados pela Fundação SEADE, os indicadores do IPRS sintetizam a situação de cada município no que diz respeito à riqueza, escolaridade e longevidade. Ao serem combinados, esses indicadores geram tipologias que classificam os municípios em grupos. São cinco grupos no total, sendo que o grupo 5 engloba os municípios mais desfavorecidos do Estado, em todos os indicadores. Os últimos dados do IPRS se referem a 2008 (FUNDAÇÃO SISTEMA ESTADUAL DE ANÁLISE DE DADOS, 2011). Apesar de apontarmos para tais índices, inclusive aqueles referentes ao IDESP de cada escola, convém salientar que não é nosso intuito relacioná-los aos desdobramentos desta pesquisa, e sim oferecer elementos de contextualização.
} 
comprometer as observações. A caracterização geral das escolas foi realizada por meio da consulta de seus Planos de Gestão - solicitados às diretoras. ${ }^{34}$

No desbravamento do campo e a partir das interações de pesquisa, adotamos o "diário de campo" - ferramenta que auxilia a transformar "uma experiência social ordinária em experiência etnográfica" (BEAUD; WEBER, 2007, p. 67), contribuindo para o registro cronológico e objetivo das situações testemunhadas. Nesta fase, a pesquisa esteve baseada principalmente em observações, enriquecida com o que emergiu do campo. Com enfoque de inspiração etnográfica, o progresso da análise, dos questionamentos, das buscas, da obtenção de informações e percepções, foi conduzido por meio de elementos anotados, memorizados, percebidos - cujas principais e mais contundentes manifestações passamos a apresentar agora.

\subsection{Características gerais}

\subsection{1 'Escola C'}

Elaborado uma vez a cada quatro anos, com vigência quadrienal, o Plano de Gestão é o principal documento de contextualização da unidade escolar. Ele oferece um retrato próprio de cada estabelecimento de ensino, sua estrutura, seus aspectos de funcionamento e as particularidades de seu grupo de servidores e discentes.

Redigido para traçar o perfil específico da escola, esse tipo de documento é produzido pela direção de cada unidade escolar, com o auxílio dos coordenadores pedagógicos, e entregue na Diretoria de Ensino da região para ser apreciado pelo supervisor de ensino geralmente aquele que é designado para acompanhar o desenvolvimento das atividades daquela escola. Após a emissão de seu parecer circunstanciado, opinando pela homologação, o Plano de Gestão segue para assinatura da dirigente de ensino.

A leitura desse documento nos oferece um esquema por meio do qual a visão, a concepção organizacional atrelada à racionalidade administrativa é mobilizada para compor as perspectivas de cada escola. Sua escrita está carregada de intencionalidade, pensada a partir dos recursos e espaços disponíveis na instituição.

\footnotetext{
${ }^{34}$ Operacionalizar questões práticas também é algo que constantemente precisa ser negociado. Pode parecer um truísmo, uma vez que é raramente expresso, mas, em situação de pesquisa, não existem objetivos e ações alcançadas automaticamente. É preciso perguntar e interpelar sobre a ocupação dos espaços. Foi assim para a consulta aos Planos de Gestão: na 'escola C' foi utilizada uma das mesas da secretaria e na 'escola O' uma mesa na mesma sala onde o documento estava guardado. Da mesma forma que a condição de espectador, esses procedimentos estão longe de qualquer coisa que se assemelhe ao natural.
} 
Visão de conjunto, visão legal, visão de recursos humanos e físicos, visão de gestão, visão pedagógica. No emaranhado de visões, o documento deixa transparecer o realce de expressões legais, procurando estabelecer seu próprio estatuto legítimo, ao destacar que "espelha-se principalmente na legislação vigente", com todas as suas "normas regimentais baseadas na LDB”. De fato, por vários momentos, a redação do documento utilizou referências legais e oficiais, citando artigos da Lei de Diretrizes e Bases da Educação Nacional (LDB), pareceres do CEE e resoluções da Secretaria da Educação.

De acordo com o Plano de Gestão da 'escola C':

[...] a unidade estabeleceu seu grande objetivo: proporcionar ao educando condições de aquisição de conhecimentos e habilidades, formação de atitudes e valores que lhe permitam ser um cidadão consciente, crítico e transformador na sociedade em que vive, resgatando valores de formação para o pleno exercício de sua cidadania e sua qualificação para o trabalho [...] ao mesmo tempo compreender e atuar na dialética do mundo, já de terceiro milênio, enquanto sujeito político, social, cultural e também produtivo, através de suas potencialidades como ser humano.

A proposta da escola, apesar de não detalhar os mecanismos a serem acionados para proporcionar as condições mencionadas, revela um plano de educação geral, com ênfase tanto na formação para a cidadania quanto na diplomação para o mercado de trabalho, além de destacar as múltiplas dimensões relacionadas ao amadurecimento do sujeito educando.

O Plano oferece o panorama da estrutura física e humana presente na unidade. Segundo o documento, a 'escola C' está organizada em três períodos e 50 classes, um diretor efetivo e dois vice-diretores, um secretário e agentes de organização e de serviços escolares, além de três coordenadores e "professores de formação específica às disciplinas que lecionam".

O total de docentes não é mencionado; há a indicação de que "cerca de 30 são efetivos, o que resulta em muita mobilidade profissional". É possível apontar que, como o quadro de docentes titulares de cargos efetivos não atende completamente a estrutura para atribuição de aulas, mais docentes são admitidos, ocupantes de categorias sem estabilidade ou em caráter temporário. Com o início do ano letivo, essa dinâmica é repetida e todo o processo de atribuição de aulas é recomeçado, o que não garante que os mesmos docentes não efetivos do ano anterior estejam com aulas atribuídas na mesma unidade escolar - gerando a citada mobilidade de profissionais. 
Essa instituição escolar atende "aproximadamente 1900 alunos", sendo composta por alunos moradores "do bairro onde está localizada [a escola]”. Segundo a classificação contida no documento, esses alunos são oriundos “de famílias de nível socioeconômico baixo”. Para o desenvolvimento das ações pedagógicas, o Plano estabelece seus critérios de normalização, suas expectativas em torno do comportamento "normal", correto, ordeiro, traçando o "perfil do aluno esperado: solidário, participativo, crítico, democrático, responsável, organizado, sociável".

É imprescindível observar que o Plano de Gestão oferece, além dos elementos destacados acima, esquemas do correto, do adequado, do esperado, do legal, da melhor organização. Nesse sentido, também dedica um espaço na escrita para consolidar a racionalidade organizacional em torno dos melhores meios, da maior eficiência e do aumento da produtividade escolar. De acordo com o documento, a gestão:

passa a abordar as relações dos envolvidos [...] aprimorando-se as questões de liderança [...] procurando um envolvimento participativo em todo o processo da escola [...] sempre com autoridade e competência, envolverá cada vez mais a comunidade escolar, pais, alunos, professores, funcionários e direção em todas as ações desenvolvidas na U.E. [Unidade Escolar].

As maneiras de lidar com os aspectos gerenciais do cotidiano revelam a mobilização de perspectivas que se interpenetram, concebidas como instrumentos simultâneos de uma prática, de uma forma de compor a organização escolar. Classificadas de "gestão com os pares escolares", ao mesmo tempo convocam os envolvidos, a autoridade, a competência, a participação e a liderança, cruzando elementos para desenvolver melhor, desenvolver mais eficientemente as atividades no ensino. ${ }^{35}$

\subsection{2 'Escola O'}

O Plano de Gestão da 'escola O', apesar de significativamente mais volumoso do que aquele apresentado na 'escola C', esteve concentrado no mesmo propósito geral atribuído a esse tipo de documento: sustentar uma concepção organizacional em torno da racionalidade administrativa, traçando um perfil específico pensado a partir dos recursos disponíveis em cada unidade escolar.

\footnotetext{
${ }^{35}$ Os trechos citados foram extraídos do documento "Plano de Gestão Quadrienal 2007-2010", o mais recente disponibilizado para consulta pela 'escola C'.
} 
A apresentação da estrutura e dos recursos da escola foi acompanhada da introdução de inúmeros anexos ao documento, como escala de férias de funcionários e informações sobre excursões realizadas pela escola. Um dos diferenciais do documento também esteve relacionado à presença de ilustrações do entorno da escola, com o uso de mapas detalhando a abrangência da unidade, os serviços disponíveis no bairro e os acessos de ruas e avenidas até a instituição.

O Plano redigido nessa escola apresentou uma escrita muito particular sobre o relacionamento com princípios organizacionais e aspectos do seu cotidiano, apontando que:

o plano delineia uma visão [...] [mas] esta visão deve ser definida em termos de metas. [...] A consolidação do trabalho coletivo na escola resulta de um processo intencional e árduo na busca do rompimento das relações de poder autoritárias, rígidas e burocratizantes. [...] De nada adiantam grandes tiradas filosófico-pedagógicas, textos herméticos e modernosos, se o grupo se mostra incapaz de assimilá-los e pô-los em prática. [...] Não há lugar, hoje, na sociedade em que estamos inseridos para uma gestão centralizadora e autoritária [...]. A gestão democrática implica compartilhar o poder, descentralizando-o [...]. Todos nós estamos sendo permanentemente avaliados. Os olhos da comunidade estão voltados quotidianamente para nossa atuação e o julgamento dela é implacável e é exatamente para impedir chegar-se a extremos negativos que o trabalho deve ser acompanhado e cobrado.

Essas formas discursivas, essa maneira de se colocar perante racionalidades e dinâmicas, revelam, de fato, um posicionamento amadurecido e específico. A posição assumida ocupa o espaço destinado à redação de um esquema escolar para conceber um esquema próprio, a partir das particularidades da unidade de ensino, de suas formas de lidar com assuntos, exigências, administração e pessoas. Naquele esquema próprio, a visão do Plano de Gestão é construída por atravessamentos: metas, humanização, aproximação coletiva, afastamento de concepções rígidas, compreensão, democracia; ao mesmo tempo, julgamento, cobrança, avaliação, preocupação, acompanhamento, compondo um conjunto ímpar de atenções e de intencionalidades.

Em mais de um momento, é possível constatar essa perspectiva no documento, colocando ênfase num plano de ação cotidiana que trata de relações concretas entre indivíduos, depuradas a partir do ponto de vista dos atores da unidade escolar: 
O princípio motivador da nossa escola é transformar a visão tradicional da escola como uma instituição fechada, externa, alheia à vida dos alunos e ao que se passa na comunidade [...] e que acredita no estabelecimento de parceria [...]. Não pensamos como pais e professores ou professores e alunos, mas sim como um conjunto de pessoas que desempenham papéis específicos e que trabalham em comum [...].

Tendo como norteadores tais entendimentos discursivos, a 'escola O' atende 1900 alunos provenientes de uma comunidade "de nível socioeconômico com renda média". Em seus três períodos de funcionamento, estão formadas ao todo 53 classes, compondo um quadro no qual atuam 117 docentes. De acordo com o Plano, “70\% dos professores são titulares de cargo; são educadores com um amadurecimento intelectual, emocional e interpessoal $[\ldots]$ ". . A estrutura administrativa segue o mesmo padrão da 'escola C': um diretor titular, dois vice-diretores, três coordenadores, secretário, agentes de organização e de serviços escolares.

Ao nos aproximarmos desse documento, podemos notar que sua elaboração esteve concentrada em oferecer um cenário de valorização individual, interpessoal e institucional, mobilizando a "gestão participativa e a abertura da escola para as janelas do mundo". A visão de administração desse Plano está atrelada ao elemento de alteridade, à consideração dos outros, ao acionamento de um conjunto de práticas que não ignora os seres humanos implicados, suas ações e articulações diárias.

Como sugerido acima, a escrita desenvolvida nesse documento é particularmente reveladora da inclusão consolidada de elementos concernentes a uma visão peculiar e a um cotidiano específico, com o intuito de "viabilizar a cidadania, [a] formação humana, desenvolver a consciência e a produção do sentido".

$\mathrm{Na}$ busca por afirmar uma perspectiva autêntica, entrelaçando os aspectos particulares da unidade escolar, o cidadão, a participação, a consciência, as metas, a organização e o sentido, o Plano concede relevância diminuta a preceitos legais e noções oficiais. Em seu apurado posicionamento sobre as dinâmicas diárias e efetivas, a escola reduz o realce de esquemas fabricados por outras instâncias, mas não os suprime. As formas legalmente instituídas, os esquemas e diretrizes legais são utilizados na medida necessária para estabelecer a legitimidade do documento - de maneira tão casual que o despacho da diretoria de ensino contido no documento aponta para a obrigatoriedade de "compatibilizar trabalho com o currículo oficial da SEE [...] sem ferir o cumprimento do currículo oficial [...] [com planos] adequados ao currículo oficial da SEE”. 
Diante de uma perspectiva em que os atores concebem e sustentam suas noções, seus esquemas e suas formas de lidar com os emaranhados legal, administrativo, pedagógico, coletivo, comunitário, as diretivas oficiais insistem num trabalho e numa ação compatível com os mecanismos legitimados, compatível com a adequação oficial e "sem ferir o cumprimento" estabelecido. No jogo de linguagem para obter a homologação do documento, para que seja "constatado o atendimento aos pressupostos previstos na LDB e Indicações do CEE", os atores convocam a escrita legal e legitimada, sustentando que "o plano da escola compreende $[\ldots]$ as diretrizes da política estadual".

Parece claro que estamos diante de lutas: de um lado, luta pela prerrogativa de pensar a construção do lugar de atuação, suas relações, de se posicionar perante as objetividades cotidianas e, por outro, luta pelos enquadramentos legais, pelo discurso oficial, pela legitimidade de esquemas e perspectivas instituídas. Nessas disputas, o texto, a escrita, o enfoque e o discurso estão constantemente sendo refeitos, procurando ocupar os espaços, as brechas, manipulando perspectivas, convocando a legalidade, cruzando práticas e expectativas para comporem esquemas e percepções sobre a instituição escolar. ${ }^{36}$

\subsection{Acompanhando práticas cotidianas - as HTPC}

\subsection{1 'Escola C'}

O contato com práticas escolares, explorando as relações e mediações operadas com a racionalidade formal-legal, foi iniciado por meio do espaço específico das reuniões de HTPC, num âmbito específico que é o das instituições públicas de ensino.

Antes de passarmos ao exame dos aspectos observados nessas reuniões, convém salientar que o Plano de Gestão da escola aponta para as expectativas relacionadas ao espaço das HTPC. De acordo com o documento, a unidade escolar

pretende utilizar os HTPCs para troca de experiências bem sucedidas entre os docentes, debates sobre problemas de aprendizagem [...] além de torná-los um espaço de formação teórica envolvendo todo o grupo num trabalho coeso que vise atingir o Objetivo Educacional da Escola [...].

\footnotetext{
${ }^{36}$ Os trechos citados foram extraídos do documento "Plano de Gestão Quadrienal 2007-2010", o mais recente disponibilizado para consulta pela 'escola $\mathrm{O}$ '.
} 
Certamente, esse é o espaço dos comentários, das discussões e debates sobre a prática, sobre os acontecimentos cotidianos, espaço de reações sobre o que acontece com os atores, sobre as formas de lidar e se relacionar com as perspectivas e aparatos oficiais.

Ao mesmo tempo em que a escola vislumbra sua percepção sobre as HTPC, os princípios, as diretivas, as formas de organização e condução das reuniões são oficialmente regidas por um Comunicado da CENP - publicado anualmente e dotado de uma escrita imperativa. ${ }^{37}$ De acordo com o Comunicado:

a Hora de Trabalho Pedagógico Coletivo - HTPC [...] se caracteriza [...] como espaço de: formação [...] dos educadores, propulsor de momentos [...] de estudos, discussão e reflexão das propostas curriculares e melhoria da prática docente; trabalho coletivo de caráter estritamente pedagógico, destinado à discussão, acompanhamento e avaliação da proposta pedagógica [...] e do desempenho [...] do aluno.

No decorrer das reuniões observadas, o planejamento, a organização, o contato com propostas oficiais, a apreciação de temas relacionados à escola e ao ensino, e as implicações para o desenvolvimento e manutenção das tarefas profissionais, são aspectos que estão colocados perante os docentes - não apenas os de caráter "estritamente pedagógico". As diretrizes que acompanham tais aspectos são apresentadas no espaço das HTPC, são colocadas diante dos atores, são compartilhadas nessas reuniões.

O trabalho de apresentar as propostas oficiais e as diretrizes legais foi conduzido pelos coordenadores pedagógicos, procurando realizar as conexões com a realidade escolar. Em todas as reuniões acompanhadas, o esquema de abertura da pauta esteve concentrado nas "novidades" administrativas, nos recados procedimentais e na operacionalização das atividades. Essas também são as motivações para a entrada da diretora e vice-diretora nas reuniões - apresentando e demonstrando projeções com relação a número de alunos em sala, número de salas, atribuição de turmas, e expectativas e procedimentos a serem observados para a realização do Conselho de Classe final.

Por meio da interlocução e mediação de atividades e funções na escola, há a aproximação do arcabouço de regras oficiais com os docentes reunidos, disseminando perspectivas em torno de compromissos, juízos, referências e noções normalizadas, dotadas de preceitos que orbitam a melhora das ações, a eficiência ordenativa, o desempenho

37 "Considerar", “elaborar", "dividir", "planejar", "prever”, "organizar" e "assegurar" são alguns dos termos utilizados. O verbo 'dever' surge oito vezes, em suas várias conjugações possíveis. As citações sobre esse Comunicado se referem ao Comunicado CENP - s/n, de 29-1-2008, publicado no Diário Oficial de 30 de janeiro de 2008, Poder Executivo - Seção I. 
"normal" das funções públicas, estimulando os atores a considerar tais aspectos em seus cálculos. Em sua discussão sobre a norma, Ewald (2000, p. 104) aponta precisamente que "a normalização [...] obriga a que cada indivíduo pense a regra da sua própria atividade não em relação à perfeição que ela poderia atingir se estivesse isolada [...], mas em relação à necessidade, sempre determinada, a satisfazer".

Nas reuniões realizadas nessa unidade escolar - uma vez por semana e com duração mínima de duas horas -, os docentes estavam sendo apresentados à proposta de mudança na matriz curricular. O documento enviado pela Secretaria da Educação previa que os docentes considerassem as alternativas oferecidas e oferecessem contrapropostas para as mudanças. A principal exigência para aqueles que desejassem elaborar suas contrapropostas era a presença de um embasamento teórico e legal, sob risco de serem descartadas como infundadas exigência ressaltada por uma coordenadora: "tudo que for colocar no relatório de propostas deve estar baseado na lei". ${ }^{38}$ A operacionalização dessa tarefa incluía a entrega do documento - por meio dos coordenadores - na Diretoria de Ensino, sendo posteriormente remetido ao secretário da educação.

As discussões sobre o assunto motivaram interpelações bastante acaloradas entre os docentes. De maneira geral, o encontro com esquemas e estratégias oficiais é portador de reações e reordenamentos discursivos distintos, revelando diferentes maneiras de tratar as questões. Para uma docente, a apreciação "é importante porque é nossa vida, nossa carreira". Segundo a coordenadora, "quando eles [alusão aos agentes da SE] vêm com proposta, é porque já está mais ou menos decidido". Em relação ao oferecimento de contrapropostas, uma docente ponderou que "eu tenho meu próprio pensamento, mas é o deles que vale".

No burburinho instalado, enquanto se ouviam expressões como “é isso que o governo quer", alguns docentes retomavam o preenchimento de diários, outros escutavam emudecidos, ou corrigiam exercícios. Estas ações constituem escolhas ativas no processo de relacionamento com diretrizes, preceitos e esquemas oficiais. No ordenamento das HTPC, colocado explicitamente por um regulamento, com exigências em torno de discussões programadas, embasamento teórico e legal, referências e tarefas a desempenhar, a indiferença revela uma opção ativa, uma forma de reação, uma carapaça dos atores diante de tudo o que lhes acontece e lhes é exigido.

\footnotetext{
${ }^{38}$ Todas as falas citadas nesta seção, transcritas no diário de campo, foram pronunciadas durante as reuniões das HTPC. No horário de realização desses encontros não são ministradas aulas na unidade, garantindo a participação de todos os professores presentes no período. Programados para acontecerem após as aulas e antes do horário de encerramento do período, esses encontros reuniram um grupo de cerca de 30 docentes.
} 
O debate vigoroso, mesclado de preocupação, foi retomado quando se constatou que as mudanças poderiam gerar a perda de aulas para os docentes, além de alterar o número de alunos em sala. A coordenadora interveio, afirmando que não teria condições de elaborar uma contraproposta embasada teoricamente e legalmente para confrontar a proposta oficial - esta última extremamente embasada em autores e especialistas para as questões pedagógicas, além de estar bem articulada e legitimada por leis e deliberações. Perante àquela impossibilidade e considerando que a contraproposta poderia não se justificar, a coordenadora complementou seu comentário: "Eles são safados: mandam um dia para encaminhar no outro. Eles mostram que somos incompetentes: nós vamos pelo senso comum e eles pela teoria [...]. No Estado é assim: faça-se a luz e acabou".

É preciso atentar para o grau de investimento necessário em torno de uma tarefa como essa: os recursos, as leituras, as pesquisas e o tempo - dimensões a serem mobilizadas com o intuito de articular uma proposta convincente e legítima, do ponto de vista teórico e jurídico, para contrapor os objetivos e esquemas oficiais traçados. O fardo oneroso de condições mentais, materiais, estruturais, temporais - pode contribuir para a construção vigorosa do conformismo, na forma de expressões como: "Que sugestão nada", afirmou uma docente, “tudo isso já está decidido. Acha que eu vou perder tempo com essas coisas? Tem peso o que a gente fala? Eles levam em conta a nossa opinião?”

É justo dizer que, com essa fala, a discussão e as sugestões são identificadas como irrelevantes, já que, segundo a docente, "vem tudo de cima mesmo... quem vai perder tempo com isso?" Para a coordenadora, haveria "um monte de coisas mais interessantes que passariam no HTPC, em vez de passar essas coisas [os projetos oficiais]". O ponto elementar que se coloca, no entanto, diz respeito a essa firme ativação de conformidade: por seu acionamento particular naquela trama, o sujeito se nega, se retrai, modera o fervor, arrefece, desanima, desmotiva - colocando-se ativamente nestas posições.

A recusa manifesta, a indiferença, o desagrado em discutir aquele tipo de assunto, daquele jeito e naquelas circunstâncias, naquele lugar e de acordo com os objetivos oficiais regulamentados - opções as quais poderíamos chamar de "ilegalidades sutis", para utilizar as palavras de Foucault (2005, p. 249) -, também podem ser compreendidas como as formas de se preservar e não soçobrar diante do emaranhado institucional. Tais condutas se aproximam de anestesiamentos e insatisfações entre os atores escolares. Nessa perspectiva, o tipo de fala professoral auxilia a vislumbrar dinâmicas que se articulam, produzindo efeitos similares a partir de aspectos díspares, como aquele apontado por Dubet (1997, p. 229): 
Um professor tem uma carreira 'biológica', quer dizer que não recebe mais quando ele trabalha mais ou melhor, ele ganha mais à medida que fica velho. Qual é a consequência deste mecanismo? É que depois de algum tempo, os professores entendem que seu interesse é se engajar menos.

Ao apontarem para esquemas nos quais "vem tudo de cima mesmo", os atores estão indicando a preeminência de planos oficiais e decisões tomadas sob a forma de regulamentos, e como tudo aquilo já vem com uma forma consagrada. Os comentários também sugerem que não há uma clara demanda por procedimentos, assim como parece não haver uma convicção para realizá-los; ao contrário, sugerem mal-estar e incômodo diante de algo que constantemente os precede - no sentido de possuir uma primazia institucional. Com a disseminação de diretrizes, o cotidiano público se vê amalgamado a elas, tornando-se parte do discurso proferido, executado, reapropriado, reorganizado, de acordo com as conveniências circunstanciais.

Ao mesmo tempo em que "tudo isso já está decidido" e "eu [não] vou perder tempo com essas coisas", na realização destas afirmações, o juízo é acionado: a figura do pesquisador está ali. Como uma súbita clarividência, a mesma docente que acabara de proferir aquelas afirmações determina que o pesquisador "não anote isso não". Esta foi a primeira, mas, como veremos adiante, não foi a única situação na qual a presença daquele ser supostamente investido de autoridade acadêmica e um poder místico de denuncismo -, provocou constrangimento entre os sujeitos dessa pesquisa. A presença de um olhar externo à instituição acionou instantaneamente o constrangimento como consciência, como capacidade de estabelecer um julgamento ético-moral sobre os comentários realizados, surgindo com esse ato a noção de que aquilo que foi dito talvez não devesse ter sido pronunciado. No lugar daquela fala, o juízo informa a aparência que deve ser assumida, o posicionamento encarado como mais adequado, o engajamento que precisa ser demonstrado perante a tarefa colocada conceitos em torno daquilo que se espera que um docente diga ou faça.

No limiar em que vários traços se cruzam na análise, é possível sugerir que a execução das tarefas em si, plenamente dispostas, com suas durações, aptidões, esquemas e regras, talvez não fossem consideradas “perda de tempo". Executá-las é ir eliminando uma série de encargos e é acumular uma série de ações cumpridas, encaradas, em boa medida, como avanço profissional. No entanto, a possibilidade de oferecer propostas, também com inúmeros investimentos em jogo, não apenas foi identificada como uma inutilidade - porque "vem tudo de cima mesmo" -, como também acionou um constrangimento diante da posição adotada, 
sendo classificada como inadequada perante uma presença externa - em relação a qual, do ponto da vista da docente, provavelmente tivesse sido melhor demonstrar mais engajamento.

Com a questão da proposta dada por encerrada, a coordenadora iniciou alguns comentários sobre o SARESP. Um dos docentes propôs selecionar alunos para a realização das provas do SARESP, visando favorecer os resultados do IDESP. A Secretaria da Educação estabelece que o desempenho escolar no SARESP seja considerado para a composição do IDESP, o qual consistirá em fator para recebimento de bônus salarial. Com determinados alunos garantindo bons resultados nas provas de avaliação, o índice da escola melhoraria e o recebimento do bônus financeiro estaria assegurado. A coordenadora logo o demoveu da ideia, sustentando que "os holofotes estão apontados para a escola e qualquer deslize será denunciado para a Diretoria de Ensino". Outros docentes também defenderam que aquele esquema não fosse feito, indicando o "risco de ter os resultados anulados" por suspeita de fraude - consequentemente, nada de bônus.

Esse caso parece ser um dos mais emblemáticos e sintomáticos em torno do relacionamento com as diretrizes oficiais. A figura do jogo como mecanismo estratégico é retomada aqui sob o aspecto da manipulação para o melhor resultado. Até o limiar seguro, onde não haveria represálias e punições, esses atores cogitam manipular aquelas diretrizes, jogar com elas e utilizar elementos previstos para alcançar resultados previsíveis. Dessa forma, eles se colocam no emaranhado de preceitos, índices, provas, e se movimentam na trama visando extrair daquelas diretrizes, das brechas identificadas, a realização de seus interesses.

Num cotidiano de recompensas e repreensões colocadas institucionalmente, os atores escolares estão ora manipulando, ora considerando os planos como atitudes inadequadas, procurando evitar desvios que tragam consequências deletérias. Nessa trama eles jogam com aspectos e elementos, procuram flexibilizar ações, movendo-se sem prejuízo por caminhos legais, recuam, esmorecem, são constrangidos, retomam o esquema oficial. Afinal, "o professor precisa incorporar o ofício", segundo afirmou um docente. Além disso, é preciso atentar para os prazos - principalmente no final do ano -, preencher diários, corrigir trabalhos, atribuir notas, controlar frequência, aprovar ou reprovar.

Após as reuniões nas quais as mudanças da matriz curricular estiveram em pauta, foi proposta uma atividade entre os docentes utilizando a Teoria do Campo de Força de Kurt Lewin. Extrapola nosso objetivo discutir e expor aqui os aspectos dessa teoria. A atividade consistia em indicar elementos de forças de mudança e de resistência, ou "o que influencia ou impede o trabalho em sala". Formaram-se grupos e cada qual realizou sua discussão. 
No encontro seguinte, os resultados vieram à tona - sob a alegação da coordenadora de que serviria "para ver como está a escola, um diagnóstico da escola". De acordo com os comentários dos docentes, os elementos capazes de favorecer mudanças, de fomentá-las e de favorecer o próprio trabalho giram em torno do "apoio da equipe gestora", a "união do corpo docente" - característica que foi retificada em seguida, uma vez que não haveria "união dos docentes nem entre os períodos" - e o "compromisso do aluno com as atividades". Por sua vez, os elementos que atuam na resistência ao seu trabalho, impedindo ou atrapalhando, estariam, segundo os docentes, no "descompromisso do aluno", na "ausência de apoio das famílias" e no "sistema". Para o grupo de docentes, "o sistema [referência ao sistema institucional de ensino] não dá autonomia de trabalho"; além disso, "o sistema está impregnado de padrões a serem seguidos", concluindo que "o que nos pega e nos deixa de mãos atadas é o sistema".

Os pontos ressaltados oferecem, realmente, uma visão coletiva sobre a escola, sobre a estrutura institucional, sobre o trabalho desempenhado e sobre os próprios docentes. Essa visão nos sugere que o trabalho de coordenadores pedagógicos e diretores é identificado como aquele que está dotado da capacidade de fazer a intermediação, a mediação, para depurar o relacionamento com as regras, as diretrizes, podendo apontar os riscos, os contornos possíveis, as novidades implantadas para gerir procedimentos na escola, em relação aos cargos e funções, os esquemas práticos diários, a interlocução com os pais e responsáveis e a defesa do trabalho docente diante de possíveis adversidades.

Atrelada a essa perspectiva, o grupo destaca que o trabalho na docência é bem desenvolvido, favorecido e facilitado quando o aluno desempenha adequadamente seu papel de aprendiz, quando ele demonstra compromisso com suas atividades e deveres escolares. Em sentido oposto, o trabalho na docência sofre reveses e obstáculos quando o aluno não demonstra aquele compromisso, quando, por sua atitude relapsa, a realização das atividades é prejudicada. Com a construção dessas noções, os docentes assinalam que o ponto crucial das atividades na escola, para o bem e para o mal, permanece no aluno. Soma-se a isso a noção de descompasso das famílias com o ensino, numa cadeia de desmotivação, despreparo, desinteresse, desinvestimento, desestruturação - uma série de conjeturas percebidas como desarticuladoras do ensino. Tais características e as figuras destacadas nas discussões das HTPC acabam sendo reconhecidas, aceitas e disseminadas como os decisivos suportes prejudiciais ao desempenho profissional da docência na rede pública de ensino.

Ainda com relação aos fatores de impedimento ao desempenho das tarefas, os docentes identificam e chamam a atenção para o fator "sistema", o elemento imaterial e 
impessoal responsável pelo ordenamento administrativo da rede de ensino, implicando na elaboração de diretrizes, na publicação de regulamentos e na disseminação da racionalidade administrativa sobre as instituições escolares públicas.

Ao destacarem esse elemento, os docentes estão efetivamente classificando a gerência sistêmica como um fardo excessivo para a unidade escolar, inclusive para eles mesmos; estão classificando como um fator de preeminência que constantemente parece tolher iniciativas, com padrões e esquemas impregnados, decidindo e dispondo sobre variados assuntos, englobando e encapsulando as decisões e ações cotidianas dos atores. Nessas circunstâncias, a regras, as orientações e a própria racionalidade legalista da estrutura escolar são encaradas como amarras sobrepujantes sobre o trabalho docente.

No entanto, vimos como, a despeito dessas amarras, os atores procuram outros caminhos, inclusive manipulando brechas e nós frouxos nessas amarras, explorando possibilidades de ação, sem prejuízo dos conceitos legais. Ao mesmo tempo em que identificam como um fardo, dotado de padronização contumaz, demonstram iniciativas que procuram passar ao largo de regras e preceitos, se colocando perante elas e tomando atitudes com elas, a despeito delas, a favor delas. Elas podem ser tanto abominadas quanto convocadas, de acordo com as circunstâncias cotidianas enfrentadas.

A partir do intenso debate suscitado pela atividade de HTPC, as perspectivas são reorganizadas, repensadas e reconsideradas, revelando expectativas de deslocamento em relação ao "sistema". $\mathrm{Na}$ ocasião, ficou claro para um docente que "a escola não deve reproduzir o sistema", tendo em vista que "o governo lança regras uniformes para escolas diferentes, escolas com realidades diversas". Considerando essa desarticulação entre diretrizes regulamentares e realidade escolar, o apontamento da coordenadora no sentido de que "o sistema não pode ser uma coisa que nos engesse" contribui para reafirmar um ponto de vista segundo o qual, mesmo perante uma estrutura enrijecida, a escola age, assume posições, enfrenta disputas, traça suas estratégias de ação, de rearticulação, transita por procedimentos e manipula preceitos administrativos envolvidos em seu cotidiano.

De acordo com a coordenadora, a rede de ensino, com todas as suas implicações, não deve ser vista como um conjunto de impedimentos à ação concertada na escola. Nessa perspectiva, a HTPC surge como a oportunidade de expor, examinar e dialogar sobre o que está acontecendo na escola, sobre o que docentes e gestores estão fazendo, as estratégias adotadas para lidar com dinâmicas diárias. A HTPC, então, extrapola seu próprio esquema, com ocasiões nas quais os encontros se estendem além do horário programado, como na reunião relatada acima. Na discussão a respeito do "sistema", uma docente ressaltou que "aqui 
se faz um HTPC efetivo e são poucas escolas que o tornam efetivo. É um momento que dá certo". Ainda segundo a docente, "nós não perdemos tempo aqui no HTPC discutindo coisas maiores - leis, governo, decreto. A gente sabe que isso interfere, mas a questão é o quanto nós vamos permitir que interfira". É possível perceber, portanto, que as atitudes e as formas de se portar tornam-se, como é indicado por Foucault (1985, p. 151), "temas de problematização, objetos de debate [...] e elementos de uma arte refletida de se conduzir".

Há um reconhecimento em relação à preeminência das estratégias estatais, e a luta se trava precisamente aí: na busca por uma posição não leniente, lançando estratégias próprias para retirar o peso e a preponderância dos meios, condições e objetivos oficiais. O princípio de conduta assim esboçado revela uma moral, uma maneira de se relacionar às regras e prescrições oficiais - ao mesmo tempo estabelecendo um entendimento e se conduzindo, se orientando, negligenciando esquemas, transgredindo alguns e respeitando outros. A fala denuncia uma operação na qual o indivíduo não age unicamente como ator, mas como um sujeito moral, procurando impedir que "as coisas maiores" obscureçam a sua forma intrínseca de se posicionar diariamente, de lidar com particularidades e se relacionar com elas. Segundo Foucault (1984, p. 37), “a ação moral é indissociável dessas formas de atividades sobre si”.

A intervenção da docente não denota uma acentuação nas formas prescritivas; ao contrário, denota a consideração sobre si, sobre a possibilidade de independência, sobre os vínculos estabelecidos - mais com os outros do que com procedimentos -, sobre o pleno domínio de si. Esse conjunto de atitudes e a busca de uma ação que module os mecanismos legais e legitimados, rearticulando a estrutura racional que lhes reveste, reverberam na constituição de um sujeito ético e na condução de sua prática cotidiana. A fala da docente denota também o quanto parece ser possível encostar e deixar de lado os grandes aparatos regulamentares diante da prática cambiável na escola, de um caminho traçado pela experiência, por um saber e um fazer. Nessa linha argumentativa, ressalvados os contextos específicos e as posições discursivas reveladas,

tudo aqui é questão de ajustamento, de circunstância, de posição pessoal. As [...] leis comuns [...] permanecem presentes, mas como se elas desenhassem ao longe um círculo bem largo no interior do qual o pensamento prático deve definir o que convém fazer. E para isso ela não tem necessidade de algo como um texto que faça a lei, mas de uma techne ou de uma "prática", de um savoir-faire que, levando em conta os princípios gerais, guie a ação no seu próprio momento, de acordo com o contexto e em função de seus próprios fins (FOUCAULT, 1984, p. 77, grifos do autor). 
Não permitir interferências, não comprometer a ação, concorrer para que os movimentos não sejam atados - aspectos como esses estão em jogo na escola, perante uma estrutura ordenativa e regulamentar racional. Jogo de lutas e disputas manifestas: luta por ignorar um sistema insistente, encarado como um conjunto carregado de padrões, diretrizes e expectativas legais; luta pela consideração de sua própria subjetividade, por dar passos de acordo com sua posição, seu entendimento, seu discernimento, com as circunstâncias ímpares surgidas e com as adaptações necessárias.

Trata-se de uma ascese para consciência de si, "para a instauração e o desenvolvimento das relações para consigo, para a reflexão sobre si” (FOUCAULT, 1984, p. 38). Não há passividade, não são meras peças articuláveis, mas sujeitos que compõem com o cotidiano formas de ajustar e responder ao que lhes acontece, seja manipulando e mobilizando esquemas legais, seja articulando pontos de vista, debatendo e agindo com indiferença lançando estas estratégias e traçando uma prática para lidar com mecanismos racional-legais.

Os encontros de HTPC nessa unidade escolar demonstraram a consolidação de um espaço voltado não apenas para discussões pedagógicas, mas principalmente para o entendimento coletivo sobre a relação com aspectos, procedimentos, esquemas e mecanismos estruturais incorporados à organização da função pública docente.

Durante os encontros - organizados pela coordenação em uma sala específica, ampla e bem equipada, com várias mesas dispostas em "U" e um grande quadro de avisos -, observamos também as reações em virtude de um festival de música realizado na escola. Esse tipo de evento tem influência direta sobre o cotidiano escolar, no sentido de suspendê-lo, convulsioná-lo, reordenando as atuações, as práticas. A reunião de HTPC imediatamente após o término do evento foi rearticulada, transformando-se no momento dos comentários a respeito das performances no festival, das risadas, da descontração. Fotos e filmagens realizadas no evento foram apresentadas e compartilhadas por todos nessa HTPC reordenada - inclusive com início fora do horário acertado e pautas desenvolvidas de forma mais humoradas.

A dinâmica esteve assim reconfigurada, revelando indícios de um cotidiano que está constantemente sendo reapropriado, a despeito das tensões e planos oficiais. Revela, igualmente, um mecanismo de escape, de amortecimento de práticas repetitivas. É a oportunidade aberta, defendida, conquistada e implantada de realizar outras coisas, de olhar com outros olhares e olhares renovados, de gerenciar experiências não instituídas legalmente, sem padrões regulamentados, desvencilhadas de diretrizes e esquemas oficiais, em suma, a oportunidade de transformar os atores em sujeitos protagonistas. 
Da mesma forma, podemos notar que o humor opera a suspensão da preeminência legal, de sua racionalidade, de sua áurea de pretensão ordenativa. Em uma das reuniões de HTPC, a coordenadora apresentou os arranjos oficiais para a implantação da disciplina de Espanhol na escola, considerando o método de atribuição de aulas, as habilidades e competências esperadas, a formação acadêmica exigida, a organização das turmas, o conteúdo a ser ministrado e o subsequente planejamento das aulas. Mais uma vez, esse grande esquema traçado suscitou debates e interpelações, mas algumas docentes desencadearam uma forma de se contraporem, de questionarem, lançando uma atitude de enfrentamento com operações acessíveis a todos: por meio de gozações e risadas.

Tendo em vista pretensões que se avolumam, prescrevendo aspectos, propondo mais competências e ações, os planos podem ser encarados de forma risível. Notadamente na discussão sobre o planejamento das aulas e os conteúdos ministráveis, as docentes iniciaram um processo de ridicularização, propondo a exibição de novelas e seriados mexicanos durante as aulas de Espanhol, citando falas, imitando personagens e bordões desses programas televisivos, para servirem de base ao desenvolvimento das habilidades linguísticas e às futuras avaliações. O momento foi tão efusivo e contagiante que provocou lágrimas de gargalhadas e não foi possível deixar de compartilhá-las.

Rir e transformar os caprichos regulamentares em motivos de gozação pode ser considerado como uma das formas acionadas para torná-los suportáveis, toleráveis e digeríveis e, em sentido complementar, embaraçá-los, acanhá-los, diminuir-lhes o vigor. De acordo com Agamben (2010, p. 62), “chama-se provocação àquela estratégia que constrange a potência da lei”. Nessa perspectiva, o deboche, a afronta, a ridicularização surgem como as estratégias mobilizadas para se desvencilhar de diretivas insistentes e oficiosas. $\mathrm{O}$ relacionamento estabelecido, assim, aciona práticas amortizadoras, procurando anular, desafiar, desqualificar regras, numa estratégia praticada para provocá-las, para torná-las desclassificáveis e apequená-las em suas pretensões.

\subsection{2 'Escola O'}

A leitura do Plano de Gestão da 'escola O' revelou as expectativas relacionadas aos encontros das HTPC. Segundo o documento: 
HTPCs podem ser momentos de ruptura com o trabalho individualizado e, simultaneamente, um tempo de formação para os professores. [...] Os HTPCs deverão ser utilizados para capacitação e para discussões mensais sobre as metas, reunindo: direção, professor coordenador, corpo docente e pessoal de apoio e administrativo.

É preciso afirmar que o "pessoal de apoio e administrativo" jamais esteve reunido nas HTPC e é exato sustentar sua nula participação nesse tipo de reunião, já que suas próprias atividades funcionais dificilmente são articuladas com esses encontros. Há uma série contínua de atribuições, obrigações e responsabilidades disseminadas nas escolas e, cada qual, de acordo com sua natureza - pedagógica, funcional, gestora -, ocupa cada um dos partícipes nessa estrutura. Sobre os funcionários administrativos recaem a gerência de múltiplos aspectos da instituição, desde o inventário sobre a merenda até a organização das questões práticas relacionadas à manutenção de cada uma das vidas funcionais e escolares, inclusive a clássica atribuição de repassar informações aos órgãos centrais da administração.

Ao iniciarmos o trabalho de campo nessa escola, encontramos os professores debatendo as propostas de mudança para a matriz curricular. ${ }^{39}$ Como na 'escola C', o documento enviado pela Secretaria da Educação previa que fossem consideradas as alternativas oferecidas e elaboradas contrapropostas, desde que fundamentadas teórica e legalmente. Os docentes foram divididos em grupos e a discussão permaneceu acalorada, até que cada um deles elaborou seus comentários gerais. Em meio ao burburinho foi possível discernir expressões como "critérios de justiça" e "número de aulas perdidas". Segundo um docente, propor que sejam feitas sugestões de mudança para a matriz curricular configura uma "tentativa [do Estado] de posar como um processo democrático e depois dizer: 'foram eles que escolheram"'.

Parece realmente que as oportunidades para colocar em evidência os esquemas oficiais auxiliam os docentes a desnudarem sua própria relação com as iniciativas institucionais. Nessa ação descortinada, a proposta de considerar alternativas para elaborar contrapropostas aparece como a tentativa de corresponsabilizar os participantes pela organização de seu cotidiano, pela gerência de suas escolhas, principalmente se não obtiverem a eficiência e os êxitos almejados. A perspectiva assim esboçada é realçada pela fala professoral, segundo a qual "me dão quatro armas [referência aos quatros tipos oferecidos de matriz curricular]... com qual eu quero atirar em mim? Com nenhuma”. A frase sintomática é reveladora, ainda,

\footnotetext{
${ }^{39}$ Durante a realização das HTPC na 'escola O' não são ministradas aulas. Assim, todos os docentes presentes no período participam dos encontros, os quais reuniram em torno de 22 docentes.
} 
da potencialidade contida em cada escolha, a qual, inclusive, pode ser portadora de uma demissão e de um anulamento de quaisquer vantagens e positividades que poderiam advir com as opções disponíveis.

Nos apontamentos realizados para a discussão, um dos docentes assinalou que "essa proposta deveria ser discutida com a comunidade. [Ela] continua vindo de cima para baixo". E não apenas isso: "começam 20 projetos e não conseguem terminar nenhum". A partir das falas e posicionamentos, podemos notar que, por um lado, o chamado à participação é visto como "pose democrática"; por outro, identificam ausência de discussão em relação a uma proposta que "continua vindo de cima". Ou seja, se os atores são chamados ao debate, isso é interpretado como mera formalidade democrática; se percebem que não há debate, é o indicativo de que os planos "estão vindo de cima". De toda forma, as noções e percepções emaranhadas e vividas se instalam ao mesmo tempo, confluem e se desarticulam, na multiplicidade de pontos de vista e maneiras de se posicionar no cenário escolar. Concomitantemente, os docentes apontam para planos, projetos e debates concebidos de maneira regulada e institucionalmente planejados, denunciando o experimentalismo de formas oficiais inauguradas e reelaboradas que desconsideram o dinamismo específico da comunidade escolar em sua administração.

Diante de tentativas e ensaios ordenativos, as sugestões são, também aqui, identificadas pelos atores como irrelevantes, e desqualificadas como atitudes que façam alguma diferença. De acordo com um docente, "seria melhor que a matriz já viesse pronta". A afirmação revela a noção de "perda de tempo" sob outro matiz: com modelos e esquemas preparados, debruçar-se sobre análises e propostas se torna uma atividade a menos a ser empreendida, na trama de atividades a serem levadas a efeito. Diante daqueles ensaios oficiais e legais, optar pela desistência em torno de sugestões e contrapropostas é a decisão vigorosa de sujeitos, é a afirmação, a preservação e a constituição de suas próprias subjetividades em contato com procedimentos regulados. Optar por esquemas assentados e se concentrar no que é preciso fazer, desempenhar e executar também faz parte das decisões e posições assumidas. Assim, e diferentemente do que observamos na 'escola C', aqueles atores produziram um documento, no qual optaram pela manutenção da grade curricular em vigor.

Com esta tarefa encerrada, as demais reuniões das HTPC acompanhadas na unidade formaram ocasiões sem propostas de discussão, sem exercícios que colocassem em debate a escola, as percepções e as práticas corriqueiras. Após a discussão sobre as mudanças na matriz curricular, não surgiram temáticas, avaliações e perspectivas a serem discutidas. Os encontros permaneceram sem proposições e apreciações coletivas, com ações isoladas e 
assuntos dispersos. Assim, em algumas ocasiões, a coordenadora apresentou recados administrativos, deu ciência de certas resoluções e, em seguida, cada qual se lançou em procedimentos solitários ou em pequenos grupos: acessos às redes sociais pela internet, leitura de jornal, arrumação de diários, conversas paralelas - alguns com fones nos ouvidos, outros com computadores pessoais abertos.

A organização das reuniões de HTPC traduz uma concepção, uma visão e uma maneira de se relacionar com aspectos administrativos e oficiais. Os atores na 'escola $\mathrm{O}$ ' reenquadraram o espaço das HTPC, concebendo uma forma particular de utilizá-lo. Nele, encontraram a oportunidade de desenvolver suas subjetividades; por meio daquelas ações, eles se afirmam como articuladores de escolhas e mobilizadores de opções, recuando e relegando os esquemas consagrados e esperados naquelas reuniões.

Não há vazio ali; ao contrário, as reuniões - realizadas em uma sala de leitura, com mesas circulares dispostas umas separadas das outras - são portadoras de uma dinâmica na qual os atores articulam com desenvoltura e conjugam o permitido com atitudes que podem ser consideradas inconvenientes, considerando o caráter oficial atribuído ao espaço das HTPC. Com efeito, de um ponto de vista meramente formal, as reuniões observadas poderiam indicar HTPC inexistentes, esvaziados, um mero cumprimento de horas - e, mesmo assim, de forma incompleta, já que os encontros começavam depois e encerravam bem antes do horário previsto -, sem maiores atividades, com atores calados, cada qual em atividades isoladas e acionadas para ocupar o tempo.

Entretanto, sob outra perspectiva, os encontros de HTPC reapropriados e reprogramados formavam o espaço para "respirar", para recuperar o fôlego e readquirir as forças. As práticas acionadas podem ser vistas como exercícios de anestesiamento, de desubjetivação, as formas encontradas para lidar diariamente com aspectos e racionalidades (legais, administrativas, pedagógicas, funcionais, regulamentares, "normais") capazes de exigir atenções diárias. Subjetivações e desubjetivações também são elementos emaranhados no interior da trama, as quais oscilam perante contextos, espaços, oportunidades, encontros e reuniões, colocadas em movimento na medida em que cada um dos atores as consideram aceitáveis, adequadas e necessárias.

A partir das reuniões de HTPC, podemos constatar que, tanto na 'escola C' como na 'escola $\mathrm{O}$ ', o espaço aberto à ação e à discussão oferece respostas díspares em contato com questões similares e ocasiões semelhantes. Os encontros regulamentados acionaram perspectivas distintas, comportamentos diversificados e maneiras de reger aquele tempoespaço atreladas ao que convém fazer, às próprias concepções. No limiar entre funções, 
obrigações, incumbências e prerrogativas, cada um dos atores - com suas escolhas, opções, posições assumidas e mobilizadas como estratégias de ação - procuram e se instalam numa relação adequada consigo mesmo, relação na qual

trata-se [...] de constituir-se e reconhecer-se enquanto sujeito de suas próprias ações, não através de um sistema de signos marcando poder sobre os outros, mas através de uma relação tanto quanto possível independente [...] de suas formas exteriores, já que ela se realiza na soberania que se exerce sobre si próprio (FOUCAULT, 1985, p. 92).

$\mathrm{Na}$ articulação com uma racionalidade normativa, o relacionamento consigo próprio é medido, avaliado, julgado, mediado e construído com base em noções "normais" e corretas. Para tal perspectiva, surge novamente a preocupação disseminada na forma de receios diante da vigilância, do olhar externo. A maquinaria indiscreta presente por todos os lados, de visibilidade indispensável - não apenas na 'escola O' como também na 'escola C' - tem como objetivo, nas palavras de Foucault, "a garantia da ordem" (FOUCAULT, 2005, p. 166). Câmeras, monitores e sensores formam um conjunto de dispositivos que capturam e revelam ações, concorrendo para torná-las mais efetivas e eficazes.

Como ressaltamos acima, a figura externa, a presença visível e vigilante do pesquisador aciona o constrangimento como consciência, diante de falas ou comportamentos fora daquilo identificado como o padrão ético. $\mathrm{Na}$ 'escola $\mathrm{O}$ ', comentários pejorativos, sobre banalidades e comportamentos desrespeitosos desencadearam um constrangimento, interpelando imediatamente o pesquisador: "você não vai pôr isso no seu relatório, vai?" Parece haver, efetivamente, um receio de ser visto como um docente e um gestor que não possui uma atitude condizente com aquilo que se esperaria ver demonstrado em suas funções, em dissonância com a ideia, o imaginário e a concepção coletiva do bom, zeloso e respeitável professor. $^{40}$

É no interior dessas práticas, dessas noções, desses princípios de pensamento e de ação - em relação aos quais às vezes se preocupam e expressam preocupação, às vezes ignoram, desprezam, agindo com indiferença e sem lhes atribuir importância - que os atores se constituem como sujeitos, como entes soberanos, numa existência entremeada por discursos,

\footnotetext{
${ }^{40}$ Com o decorrer dos encontros, alguns docentes se aproximam mais, querem saber detalhes do estudo, se interessam e demonstram simpatia e cordialidade. Outros simplesmente agem com absoluta indiferença e até mesmo certo desprezo por estarem sendo observados no que estão fazendo. Foi assim com a própria coordenadora das reuniões acompanhadas nessa escola: desde o primeiro dia houve certo incômodo, mesclado há um mal-estar, mas certamente uma indiferença, expressa na forma de falta de cortesia, de não cumprimentos e de ausência de convites para que fosse possível se dirigir à sala de realização das HTPC no momento oportuno. Nada disso, porém, impediu ou prejudicou a realização de nossas observações.
} 
formas oficiais, procedimentos legais, estruturas, organização, administração racional e ordenada. Nessa trama, sua ação está situada e mediada, sendo constantemente feita, refeita, ponderada e articulada diante de dinâmicas oficiais perenes no cenário escolar.

\subsection{Acompanhando práticas cotidianas - o Conselho de Classe}

A aproximação às práticas no âmbito escolar, explorando as relações acionadas perante instrumentos racional-legais, foi prosseguida por meio das reuniões do Conselho de Classe final na 'escola C', realizado para o término do ano letivo.

O entendimento e a visão sobre o Conselho de Classe estão contidos no Plano de Gestão da unidade escolar, de acordo com o qual cabe à escola:

[...] realizar Conselho de Classe com a presença de todos os envolvidos no processo (direção, vice-direção, coordenadores e professores), para que haja o comprometimento de todos, assegurando que o aluno seja avaliado pelo grupo e que suas dificuldades, caso existam, sejam colocadas com clareza, sendo também esclarecidas as recomendações que o professor fará ao aluno e seu responsável.

Obter autorização para acompanhar o que acontece no espaço institucional do Conselho de Classe é um privilégio e uma oportunidade ímpar. Presidido pela diretora da escola, nesse espaço estão envolvidas, de maneira acumpliciada, administração e decisão. Efetivamente, esse é o momento de decidir aprovações e reprovações a partir das notas atribuídas pelos docentes. Com uma sequência atribuída a partir das disciplinas, cada um fala as notas e faltas de cada aluno, de cada disciplina, de cada turma, quase sem interrupções. Nomes raramente aparecem, substituídos e revertidos em números e múltiplos preenchimentos - diários, fichas, relatórios -, em relação aos quais devem ser evitadas rasuras. São conceitos convertidos numa avalanche de números, esperados pelos formulários, e todos os números devem conferir com todos os registros.

O registro de todas as notas e faltas esteve sob responsabilidade da própria diretora da unidade escolar, anotando em fichas individuais de cada um dos alunos e confirmando a decisão final. Esta decisão - a qual pode assumir as formas de "promovido", "retido", "transferido", "abandono" ou "reclassificado" - foi sistematicamente registrada pela vicediretora em listas gerais e pela coordenadora na Ata do Conselho, conhecida como "lençol" uma alusão ao tamanho superdimensionado da folha. Cada classe possui sua própria ata ou 
"lençol"; em cada ata são anexadas as tarjetas - tabelas com todas as notas e médias finais de cada uma das disciplinas, preenchidas por todos os docentes -, compondo o panorama do desempenho de todos os alunos da escola.

Com as notas anexadas e o preenchimento concluído, a ata se torna o registro oficial a partir do qual os resultados são transferidos para o Sistema de Avaliação e Frequência da Secretaria da Educação - um sistema informatizado de acesso restrito ao pessoal administrativo encarregado de digitar aqueles resultados na escola. Processados pelos gestores daquele sistema, os registros são impressos e se transformam no boletim do aluno.

Uma das decisões mais debatidas e meticulosamente examinadas pelo Conselho de Classe diz respeito aos casos de reprovação. Ao lidarmos com reprovações em escolas públicas, é preciso lembrar que turmas de oitava série do ensino fundamental e terceiro ano do ensino médio são passíveis de reprovação por baixo desempenho e número excessivo de faltas. As demais turmas não possuem mecanismo de retenção, exceto por faltas em excesso. De acordo com aquilo que foi possível apurar durante as reuniões do Conselho, para cada aula, de cada disciplina, a presença ou a ausência é indicada. Considerando a somatória geral das ausências no ano, se o aluno ultrapassar o limite em torno de 270 faltas, o qual pode variar dependendo do número de aulas dadas, ele é classificado como reprovado.

A partir de um princípio repetido insistentemente segundo o qual "o Conselho é soberano", observamos uma mescla de alterações, ajustes, mudanças decididas, um jogo de composição em torno daquele limite de faltas, do desempenho do aluno, além do temor por procedimentos que não estejam "dentro da lei”. As adulterações da vida escolar estavam geralmente ligadas aos casos em que o aluno apresentou desempenho insuficiente na maioria das disciplinas, alguns conceitos satisfatórios e número de faltas equilibrado - o que já autorizaria a reprovação, para as turmas no final do ensino fundamental e do ensino médio.

Buscando evitar margens de dúvidas em relação à decisão acertada - aspecto complementado por uma intensa e realística apreensão de que os responsáveis pelo aluno entrem com recurso na Justiça apelando contra a decisão pela reprovação -, por iniciativa da diretora, todas as notas são rebaixadas e todas as faltas aumentadas, de forma a traçar um perfil mais dramático do que o realmente apresentado, e assim justificar plenamente a inevitável reprovação.

Esse tipo de alteração, realizada pelos membros do Conselho, não representa a realidade, mas ganha veracidade nos registros, e se torna a verdade oficializada, acrescida de comentários de um docente e uma vice-diretora, respectivamente: "retido com louvor"; "tem aluno que enche o saco o ano inteiro. Dá um prazer mórbido retê-lo. Eu sei que é antiético, 
mas eu sinto muito". Nesses casos, principalmente, não deve haver discrepância na média final. Segundo a vice-diretora, "a direção tem autoridade, pelas leis e [pelo] Estatuto do Magistério, para interferir e alterar nas notas atribuídas pelos professores quando for necessário". O real então se transubstancia em real deliberado - o tipo de consenso que, como defende Rancière (2007, p. 69), não passa de uma "redução à gestão de interesses".

De fato, trata-se de uma articulação e uma mobilização em torno de interesses, dos interesses daqueles atores, os quais estão constantemente sendo transpassados pela necessidade de gerir decisões a partir das escolhas possíveis. Nessa tarefa, o número de faltas é a artimanha ou a válvula disponível para reprovar, para articular um mecanismo de repreensão incisivo sobre a vida escolar, o "troco prazeroso" ou o resultado apropriado sobre aqueles alunos que "encheram o saco" e importunaram as atividades o ano inteiro.

Então, a lei, os estatutos, os regulamentos, a autoridade são convocados para interferir, para atuarem em favor das intenções dos atores, para serem aplicados no mais fino e fundamental esquema oficial previsto pela racionalidade legalista e assim neutralizar indivíduos. Docentes e gestores estão o tempo todo elegendo alvos em torno da noção de "problema", como salientou a diretora da unidade: "o que a gente faz aqui [aumentar número de faltas e rebaixar notas] é se o aluno é indisciplinado e nos dá problema". O uso decisivo e penetrante de procedimentos respaldados legalmente está diretamente relacionado aos alvos identificados, aos interesses em jogo: de acordo com as circunstâncias, aqueles atores podem convocar ou manipular os aspectos oficiais disponíveis, inclusive adequando e sobrevalorizando o mau desempenho do aluno para estarem mais afinados com os cenários previstos em lei, numa execução conveniente visando evitar apelações judiciais.

Nos casos em que promover é a articulação em jogo, os nivelamentos acontecem por baixo, com o suficiente para ser considerado promovido, ou seja, geralmente atribuindo nota 5,0 (cinco). O bom comportamento na escola, apesar do fraco desempenho, também é ressaltado nesses casos. Segundo a diretora, "aluno com 'azul' [notas acima de 5,0] só no $4^{\circ}$ bimestre e querer aprová-lo é empurrá-lo, me desculpe”. Entretanto, a decisão da maioria dos docentes foi pela aprovação, em virtude de sua boa conduta.

Nessa conjugação de aspectos, as perspectivas às vezes se desconectam, se desalinham, para em seguida serem rearticuladas e recompostas, como é possível notar na intervenção da diretora: "se o outro passou porque era bonzinho, esse daqui também passa porque pelo menos ele tem notas". Mais uma vez, se elegem alvos e escolhas: ao "alunoproblema", a incisão da lei; ao aluno "bonzinho", a redenção. As mesmas transições entre perspectivas também se aplicaram ao caso de uma aluna gestante de 13 anos: o número de 
faltas autorizava a reprovação, mas a análise do histórico escolar e um acordo entre os professores fizeram com que ela fosse promovida, subtraindo e anulando as ausências que já haviam sido registradas. Ou seja, os atores permanecem manipulando e oscilando entre decisões legais e escolhas acertadas, opções assumidas a despeito dos critérios formais e oficiais, com suas ações sendo transpassadas por uma carga valorativa, tributária, por sua vez, de suas formações profissionais e dos lugares sociais que ocupam.

O caráter dessas transposições entre o legal e o acordado não passam despercebidas pelos próprios atores. A diretora da escola ressaltou, durante as reuniões do Conselho, que “aluno com tudo 'azul' não tem como [reprová-lo]... todo mundo perde o cargo". Nessa fala, ela denota o limite entre o legal e o ilegal para estabelecer ações e assumir posições. Até certo ponto, é possível avançar, a partir do lugar soberano de cada um; dependendo das gradações em evidência, pode ser necessário recuar, recompor estratégias e utilizar o arsenal legalnormativo, para evitar consequências desagradáveis. Até o limite em que é possível tomar decisões sem sobrevir uma penalidade, os atores na escola compõem suas escolhas e as articulam em suas práticas, num processo que consiste precisamente em lidar com a gestão do legal e do ilegal.

Nas ações que aqui vislumbramos, os atores se constituem como sujeitos de uma relação constantemente fundada e ponderada entre o que se deve fazer e o que se deve evitar, o que é possível realizar e aquilo que pode resultar em repreensões oficiais. Essa busca por modos de se posicionar no contexto escolar é a própria "procura de uma nova maneira de refletir a relação que convém ter com [...] as próprias funções, as próprias atividades e obrigações" (FOUCAULT, 1985, p. 91).

A exata percepção de que aquilo que é possível fazer, no jogo que é possível manipular, não seja legalmente correto ou institucionalmente autorizado, é expressa pela própria diretora da escola, novamente motivada pela presença do pesquisador: "esse Conselho sendo gravado, vai todo mundo aqui perder o emprego". É preciso esclarecer que as reuniões do Conselho observadas não foram gravadas por nenhum tipo de equipamento eletrônico; o termo "gravado" se referia precisamente à presença daquele olhar externo no ambiente escolar.

O importante a ser destacado, no entanto, é a compreensão sobre as possibilidades de reação aos ilegalismos: aqueles atores podem responder a processos judiciais, sofrer punições, penalidades administrativas, exoneração e demissão do serviço público. Na batalha pela preponderância ordenativa, a administração estatal reage por meio dos instrumentos regulamentares e normativos, reforçando as repreensões e o planejamento de ações mais 
produtivas e eficientes. A partir da perspectiva esboçada, é possível apontar que, de acordo com Ewald (2000, p. 45), "o poder serve, permite, favorece, ou, pelo contrário, refreia, constrange".

O enquadramento da normalidade é realizado, em certa medida, por meio de mecanismos jurídicos e oficiais, os quais atuam como apoios e suportes de processos regulares institucionalmente disseminados. A punição, nesse esquema, aparece como o instrumento acionável e aceitável - uma vez que é acionada pela própria Justiça, por mecanismos legais e legítimos - capaz de despertar receio em relação ao distanciamento da norma, capaz de atuar na condução das condutas. Para objetivar ações e atenuar sanções, docentes e gestores normalizam suas práticas, dinâmicas nas quais, de acordo com Foucault (2005, p. 251), "todos fazem reinar a universalidade do normativo". Punir torna-se o apelo aceitável para que os sujeitos recuperem a racionalidade normativa, administrativa e ordenada.

Lidar com legalidades também pode resultar numa absorção do discurso oficial. As reuniões do Conselho de Classe - em maior medida do que as reuniões de HTPC - revelaram docentes muito impregnados por esse discurso, acionando-o convenientemente a partir das situações surgidas. "Promovida pela legislação" e "aprovado pelo sistema" foram expressões recorrentes nesses casos, pronunciadas pela coordenadora para sugerir que os alunos progrediram porque a lei permitiu, e não porque seria o resultado de seus méritos. De toda forma, quando a regulamentação é convocada nas deliberações do Conselho, há uma integração dos preceitos oficiais no exercício contínuo das atividades, nas visões acionadas por cada um dos sujeitos.

O modelo da legislação proeminente, da grande justiça, do inexorável sistema é a caução lançada para lidar com mecanismos normativos, com as decisões, reprovações e repreensões que eles autorizam. A força sugestiva de opiniões que identificam a "decisão da legislação" acaba disseminada e "independe da verdade ou do erro que contenham; reside unicamente em seu prestígio" (LE BON, 2008, p. 124). Ao utilizar essa influência superestimada de estruturas oficiais e mecanismos legais, o Conselho de Classe acaba por atuar como o espaço estratégico de normalização e objetivação, colocando diante de discentes - e reafirmando aos próprios docentes - disposições de rigor e condenação ao desvio, às anomalias identificadas a partir da proliferação de faltas e más notas.

É em torno desses desvios e irregularidades que uma economia jurídica se levanta, se aperfeiçoa e se mantém como expressão e tática para práticas regulares. A escola, nessa perspectiva, está povoada pelo estabelecimento de regularidades e pelo surgimento de 
desvios, pelo entrecruzamento ocasionado por essas duas dimensões elementares no cenário institucional cotidiano.

Diante da capacidade de estabelecer um julgamento ético-moral sobre os comentários e atos realizados, parece haver um esvaziamento de responsabilidade, um anulamento ou uma demissão subjetiva quando se fala em "promovida pela legislação". A fala imputa a uma cadeia regulamentar o predomínio de critérios, decisões e opções que se mostraram articuláveis, manipuláveis, as quais assumiram, por vezes, formas subjetivas e qualificativas. A "promoção legal" não surgiu como uma fala de conotação irônica, mas como uma noção atrelada à supremacia da razão legalista, oficial e legitimada. As regras legais, oficialmente prescritas, são amalgamadas às práticas - uma racionalidade que é passível de concordância, identificada como uma forma de dispor eficientemente as dinâmicas escolares. Nas demonstrações e comentários que suscitam, permanece revelada a ação possível num cenário público - cenário a ser reorganizado pela atuação de cada ser humano, ator e sujeito implicado na estrutura que o precede -, capturando modelos, os utilizando, deixando de lado, os rearticulando na trama escolar por meio das escolhas mais convenientes.

Além disso, não podemos deixar de destacar uma discussão que tangencia as “aprovações pela legislação". Parece exato sustentar que as falas e pontos de vista provocam e ao mesmo tempo se entrelaçam a outras características, as quais dizem respeito à responsabilização. O conceito de responsabilidade, como evidencia Derrida (2010, p. 38),

regula a justiça e a justeza de nossos comportamentos, de nossas decisões teóricas, práticas, ético-políticas. Esse conceito de responsabilidade é inseparável de toda uma rede de conceitos conexos (propriedade, intencionalidade, vontade, liberdade, consciência, consciência de si, sujeito, eu, pessoa, comunidade, decisão etc.).

Ainda com Derrida (2010, p. 123), absorver e demonstrar responsabilidade possui como condição "a ausência de critérios gerais e de regras automáticas". Com efeito, os comentários sobre "a legislação" ou "o sistema" constituem uma demonstração da tendência disseminada de "falar em generalidades" (ARENDT, 1999, p. 320). Há, então, ações atribuídas ao "sistema", à "lei", à "legislação". No entanto, a própria coordenadora retoma o caráter preciso da relação ética, a consciência da decisão, ao deparar-se com expressões generalizantes e impessoais: “[ele] não é uma coisa, é um aluno”. De fato, são pessoas lidando com pessoas, com procedimentos e decisões que afetam o desenvolvimento de vidas escolares. 
O Conselho é a oficialização das avaliações, mas, de acordo com a coordenadora, "têm professores que não conseguem fazer uma avaliação do aluno condizente com o que ele realmente aprendeu, concentrando a avaliação na média aritmética”, ou seja, naquilo que é exigido pelo "sistema". Nas contas e cálculos de cada um, o espaço para a consideração de elementos subjetivos é ativamente tolhido em dada circunstância, e a reprovação aparece como a escolha utilizada para tentar melhorar o aluno no próximo ano. "Merecido", "ele é hiper... hipersafado" ou "quem mandou não vir para a escola?" - são os comentários em relação aos resultados obtidos em suas aritméticas, na qual estão implicados os alunos não promovidos, construções semânticas e respostas em tons que sugerem um descolamento da atuação docente em direção à desqualificação situacional daqueles alunos. Segundo informação da diretora, dentre oito turmas de oitava série, cerca de 90 alunos foram reprovados ou retidos nesse Conselho de Classe.

No desenrolar das ações, a ríspida declaração da vice-diretora de que "os professores aqui têm dificuldade para se posicionar" revela ocasiões nas quais há uma tentativa do grupo de se adequar, de concordância, de "conformidade a qualquer preço" (ARENDT, 1999, p. 194) - certa aproximação com o arsenal oficial que indica uma legalização ao extremo. Com as "promoções pela legislação", os sujeitos na escola estão imputando ações e decisões humanas a inumanos, procurando legitimar e justificar suas decisões de uma maneira que possa convencer aos outros e a si próprios, articulando e compondo com o arsenal regulamentar suas próprias escolhas.

As atividades do Conselho por vezes surgem como práticas tão irritantes que estimulam a coordenadora a comentar: "eu preferia dar seis aulas seguidas do que ter que fazer isso [organizar a documentação do Conselho]". Não foi possível deixar de notar momentos não raros de comportamentos bastante irritadiços entre os professores - uns com os outros e com a presidente do Conselho, isto é, com a diretora. As falas, as atitudes, os olhares, os assopros de inquietude, as impaciências, o nervosismo com as canetas são aspectos que deixam transparecer certo desconforto com procedimentos, regras, cuidados, atenções, manipulações, num relacionamento que pode assumir sinais de rispidez, de pressa, de aspereza, de silêncio, de anestesiamento, de frieza, com comentários inflamados, procurando, por variados posicionamentos, sanar fraturas e concluir tarefas.

Não é nosso intuito fazer aqui, em relação a esse ponto, uma digressão muito extensa e tampouco nos aproximarmos perigosamente de comparações e situações ocorridas sob um regime totalitário. Antes, trata-se de extrair noções precisas que expandam o entendimento sobre aspectos levantados. Nesse sentido, convém observar que em boa parte dos ensaios 
contidos na obra Responsabilidade e julgamento, Arendt identifica a necessidade de reencontrar o "caso Eichmann" sob a perspectiva da responsabilização. Alegar que "o sistema" é o responsável e o indivíduo é apenas "um dente na engrenagem" não anula a importância decisiva daquele que decide, do executor. De fato, para Arendt (2004, p. 94), "a questão da responsabilidade pessoal [...] [não permite] a transferência de responsabilidade do homem para o sistema". Ainda assim, "esse sistema não pode ser deixado fora de cogitação".

$\mathrm{Na}$ esteira dos desdobramentos do julgamento de Eichmann, Arendt (2004, p. 162) expõe o necessário critério de certo e errado como a resposta à pergunta: “o que devo fazer?", a qual denota o princípio de dúvida inerente à execução de toda ação. O questionamento, a discussão, o diálogo e o debate circunstanciado abrem o leque de possibilidades, as escolhas disponíveis, a apreciação e a decisão moral identificada como a mais acertada. Diante de situações de indecisão entre aprovar ou reprovar alunos, a primeira e instantânea ação durante o Conselho foi fazer circular suas fotos e, em seguida, promover uma votação, procurando veredictos em torno de instrumentos classificatórios e confiáveis.

As considerações acionadas envolveram ainda as preocupações com o pesquisador, com seu possível julgamento. “O que o nosso pesquisador vai pensar?”, questionou uma das vice-diretoras. Práticas e falas acompanhadas acabam despertando em cada um a preocupação e o constrangimento com aquilo que pode suscitar, com os limites éticos das ações, com supostas condenações, recriminações ou opiniões negativas sobre o que deveria ou não ter sido feito. A afetação diante da presença externa revela uma consciência de certo e errado, de legal e ilegal, noções que já existiam, de maneira latente, antes que os atos fossem concebidos e oportunamente praticados.

$\mathrm{Na}$ relação instalada com o arsenal regulamentar, o Conselho de Classe evidenciou que os atores se aproximam, deixam de lado, retomam, ignoram, redobram a atenção, articulam e desarticulam aspectos de acordo com suas próprias perspectivas, intenções, decisões e pontos de vista. Eles estão colocados na trama emaranhada, repleta de fios e aspectos entrelaçados. Como os fios do títere, aqueles atores os puxam e os soltam considerando os movimentos que pretendem empregar.

Dessa forma, o cotidiano não se reduz à execução da lei e, simultaneamente, não se prescinde da racionalidade formal-legal. Docentes e gestores sabem transitar em meio aos mecanismos institucionais e conseguem articular ações, posições e decisões na trama regulamentar. No jogo de disputas entre a racionalidade legalista e a soberania de si próprio, eles realinham suas estratégias e mobilizam os aspectos disponíveis para alcançar formas proveitosas de gerir os assuntos escolares. Como jogadores experientes, sabem jogar o jogo, e 
jogam precisamente para a execução mais eficiente de suas próprias tarefas - mesmo que, às vezes, tenham que se recobrir com um discurso legal e com noções oficializadas.

O acompanhamento ao Conselho de Classe demonstrou que os atores sabem perfeitamente bem mover-se e situar-se no emaranhado legislativo, a ponto de manipulá-lo satisfatoriamente. Na perspectiva traçada, a ilegalidade se impõe como uma artimanha para dispor situações e alcançar resultados convenientes. Para que a escola obtenha um bom desempenho, os sujeitos precisam saber dispor o aparato regulamentar e manipulá-lo, levando em conta os interesses em jogo, as decisões a serem concretizadas, no limiar entre legalidade e ilegalidade. Assim, aqueles atores estão gerindo legalidades e ilegalidades num ambiente em que preceitos, regulamentos e procedimentos são ignorados, utilizados, ponderados e ajustados de maneira eficaz.

\subsection{Da escuta à compreensão: relatando uma entrevista}

O trabalho de observação e acompanhamento de práticas escolares revelou aspectos primordiais em relação às maneiras como os sujeitos lidam com procedimentos e perspectivas legais. Inspirados pelos desdobramentos constatados, procuramos interpelar e ouvir um dos atores que transita precisamente entre a racionalidade oficial como exercício funcional e a aproximação com distintos cenários escolares, explorando seu ponto de vista a respeito da relação cotidiana com os aspectos oficiais.

Com 23 anos de experiências na rede estadual, tendo ocupado as funções de docente e coordenadora pedagógica, a entrevista foi realizada com uma supervisora de ensino - cargo que desempenha na rede estadual desde 2004. ${ }^{41}$ Para Ezpeleta e Rockwell (1989, p. 68),

sua mediação transforma em organização escolar concreta o mais sofisticado planejamento técnico, reforça os mecanismos de controle do magistério,

\footnotetext{
${ }^{41}$ Para a concretização da entrevista, foi necessário organizar dois encontros, ocorridos em julho de 2012. O primeiro encontro ocorreu nas dependências da Diretoria de Ensino onde a supervisora atua. A entrevistada considerou conveniente que realizássemos a entrevista durante seu plantão. Nesta oportunidade, incontáveis interrupções minaram o desenrolar da entrevista, revelando o quanto é inapropriado realizar esse tipo de tarefa sem que o entrevistado tenha feito uma pausa em sua atividade profissional. Ciente da incompletude da tarefa, a supervisora marcou outro encontro, agora em sua residência, para darmos continuidade, oportunidade em que a entrevista foi concluída de forma mais tranquila e proveitosa. Com o fim da entrevista, a tarefa de transcrevê-la foi, sem dúvida, a mais trabalhosa e delicada. Escrever falas é sempre desafiador, já que consiste num processo realizado a partir de avanços e recuos (principalmente recuos), onde a escrita, com suas artimanhas gramaticais e suas convenções simbólicas, tenta acompanhar o pensamento que se organiza em som, ao mesmo tempo em que procura considerar os ritmos e as tonalidades das falas. Também não resta dúvida que o depoimento tornado escrito é a essência, o conjunto de aspectos que carrega a riqueza da vivência, a riqueza de lidar com as coisas e falar delas.
} 
torna operante o sistema escolar de massa. [...] Em sua própria atuação, os supervisores apresentam o jogo possível de apropriação e controle entre magistério e Estado.

A despeito de enfoques que procuram realçar a atuação mediadora de supervisores em termos de "organização concreta" e "controle do magistério", o mérito de algumas abordagens teóricas reside na relevância e importância reconhecida a atores que não os docentes, contribuindo para o entendimento da articulação de ações entre indivíduos no ambiente de ensino. Na mesma perspectiva surgem os funcionários administrativos - encarregados de dar andamento a aspectos escolares que se entrelaçam diariamente -, em relação aos quais recaem investimentos em formação e exigências de aperfeiçoamento constante, como as convocações para cursos de atualização - dimensões que também auxiliam a reconhecer o espectro alargado de relações e ações que compõem as escolas.

A relevância das atuações de diversos sujeitos na estrutura da unidade escolar é destacada pela supervisora, reconhecendo a presença de elementos regulamentares disseminados por funções institucionais. O comentário denota que a organização do tempo e das ações não é exclusividade do cotidiano de diretores de escola. Prazos e obrigações perpassam os atores escolares, sem exceções:

[...] todas as legislações educacionais, se você separá-las, todas elas vão implicar em várias ações de vários atores. [...] Então você vai mais coordenando do que impondo ou... Às vezes você precisa ler com eles pra clarear alguns pontos, mas a sua grande maioria são eles que fazem e acontecem, transformam a legislação que está morta em vida.

Sem elucubrações e sem preocupações aparentes com aquilo que talvez não devesse ser exposto, a vida que surge no discurso - e que surgiu ao observarmos as práticas - é um contexto de manobras em torno daqueles elementos regulamentares, de acordos, de negociações, de manipulação da ilegalidade - uma autêntica arte de explorar os meios disponíveis e as condições mais favoráveis, tendo em vista os interesses e objetivos em jogo. A própria construção da carreira pública está enredada por tais dinâmicas:

[...] exerci um período também como coordenadora, mas por ser professora do CEFAM [Centro Específico de Formação e Aperfeiçoamento do Magistério] - que o processo de coordenação na época você tinha que fazer aquele processo de ir, fazer entrevista, ser selecionado pela própria escola, pelo Conselho - e por ser professora do CEFAM, eu fui proibida por lei, porque o CEFAM não autorizava você como professora do CEFAM se 
afastar para exercer qualquer outro cargo ou qualquer outra função, e eu passei na seleção numa escola [...] em Osasco, as minhas aulas foram atribuídas e quando, um mês depois, o supervisor veio dizer que eu não poderia estar designada na função de coordenadora pedagógica, nessa situação, por ser professora do CEFAM, e nós acabamos fazendo um acordo, eu passei seis meses sendo coordenadora pedagógica, e as minhas aulas, como já tinham sido atribuídas, pra que não implicasse na vida funcional da professora, eu tive que retornar pro CEFAM no final de dezembro, e foi onde eu rompi com o CEFAM [...].

A posição assumida pela supervisora, ao discutir seu cotidiano de regulamentações, tarefas, decisões e ações, orbita o reconhecimento de procedimentos e esquemas legais extremamente arraigados e entrelaçados e, ao mesmo tempo, maneiras de gerir aquela legislação, de destrinchá-la, tornando-a palatável, acessível, ajustável.

Eu parto do princípio de que a gente precisa fazer leituras sistematizadas mesmo, nós somos meio que obrigados a fazer uma leitura sistematizada da legislação. [...] Então tem a parte da legislação, que nós somos meio que obrigadas a... cumpra-se mesmo; têm procedimentos que implicam em você seguir essas leis, porém a situação mais como supervisora, eu trabalho muito... nessa humanidade do que como esse pessoal exerce. [...] Então nós estamos fazendo sempre ações que, não que vão contra a própria legislação, mas que essa legislação possa ser mais humanizada. Por exemplo, recuperação e reforço. A legislação de recuperação e reforço chegou, tinham que ser selecionados os alunos, tinha que fazer um diagnóstico, tinha que montar as turmas, tinha que cumprir a lei, tinha que atribuir as aulas, $e$ todo esse processo cabia ao coordenador. Os nossos coordenadores pedagógicos eles não tinham noção do que era isso, não liam legislação. Nós, a partir de um curso de capacitação, daquele curso que não é oficial, que é o curso que nós fazemos dentro de um espaço da escola, do próprio núcleo, eles vão... então a gente começou a fazer um trabalho assim: desde a leitura da legislação, o que eles tinham que fazer, o que estava por trás de cada artigo, ensinamos a eles fazerem o diagnóstico... então nós estamos fazendo com eles uma ação de pegar essa legislação e transformá-la em vida, porque eles têm que cumprir. Não dá pra você discutir que não tem que cumprir. Mas você tem que fazer com que... o responsável pra fazer com que essa legislação aconteça entenda esse percurso. [...] Ultimamente eu tenho dito assim: o peso já está difícil, nós já carregamos um peso muito 
grande nas nossas costas. Então você ter um supervisor a mais pra forçar essa... esse peso... colocar mais... vai ser mais difícil. [...] Às vezes eu acho que eu deveria ser mais exigente, mais legisladora... cumpra-se... mas eu não consigo... [...] Então eu tenho uma lei, a lei estabelece vários passos, a escola como coautora da implementação dessa lei ela tem que fazer [...] cabe à escola, em última instância, a fazer todas as ações. Então uma das coisas que nós conseguimos com esse grupo de coordenadores foi que eles começassem a ler as legislações. [...] E ele tem feito as leituras sistematizadas das legislações. [...] Porque quando eles fossem falar com os professores, eles também possibilitassem a eles a leitura e até a discussão disso. Então hoje você pega, nas atas de HTPC das escolas que estão sob a nossa responsabilidade, esse viés das leituras de legislações, coisas que não tinham antes. Então, eu tenho forçado meio que a barra nesse sentido, de que eles peguem uma lei, que eles leiam enquanto coordenadores pedagógicos e que eles passem isso pros professores, que eles disponibilizem os sites pros professores [...] mas ainda há uma resistência muito grande. Os nossos professores eles não se preocupam muito - eu estou dizendo a minha percepção - de que eles são... tudo o que eles fazem tem um " $q$ " legislativo, eles não conseguem entender isso, parece que a coisa num... como se a legislação tivesse bem longe, lá na Secretaria da Educação, eles tivessem aqui na escola e não tem nada a ver. Então a gente tem feito uma discussão um pouco mais assim - o que eles determinam lá em cima interfere drasticamente no que você faz aqui embaixo. Então você precisa... então os referenciais tem que ser lidos, todos os documentos... caderno gestor, o professor precisa ler essas coisas, ou o PCP [Professor Coordenador Pedagógico] precisa ler esses documentos oficiais, porque é os documentos que traduzem, as leis traduzem o que a Secretaria acredita ou não pensa e a gente está aqui dentro. Se você está dentro você tem que aprender as regras do jogo; você pode não gostar das regras do jogo, mas sabê-las... você é obrigado a saber.

A partir do ponto de vista da supervisora, parece haver sobre a escola expectativas fundamentais em relação à execução das diretivas oficiais. Em consonância aos preceitos que são esboçados pelas regras, há a consideração da prerrogativa da escola em realizar as tarefas. O discurso conclama os atores na escola a estreitarem os vínculos com a dimensão regulamentar, fazendo parte de suas considerações, "porque eles têm que cumprir". 
Estão imbricados nessa áurea de legalidade ritos procedimentais próprios de uma retórica regular e rigorosa, os quais buscam fixar atos, trâmites e a eficácia de seus ordenamentos. A legislação aparece então como os suportes alicerçantes dos empreendimentos da escola - aparência na qual a lei e seu caráter afirmativo dizem respeito às "regras do jogo". Dominar essas regras é se sair bem no jogo, é jogá-lo com desenvoltura e, nesse processo, absorver a experiência necessária para lidar e manipular com sucesso procedimentos, diretrizes e ações na escola.

Com o domínio das formas de se relacionar com diretivas legais, aquele aparato regulamentar apontado no Capítulo 1 deste trabalho sofre desconexões, desvios e descolamentos com o fazer diário dos atores. Os caminhos da prática avançam na desmistificação dos aspectos oficiais, tomam contornos definidos por suas próprias experiências e a potência dos marcos regulatórios do ensino acaba reduzida, minimizada, diluída e não tão fortemente implicada no cotidiano.

As regras ou os "dispositivos organizatórios", na expressão de Adorno (1995, p. 109), são os instrumentos empregados para fundamentar decisões, os alicerces que procuram suportar a padronização, a estabilidade, e o traço de "governamentalidade" para práticas normalizadas. Como a supervisora destaca, os regulamentos revelam as crenças institucionais em torno da organização escolar, as formas concebidas e assumidas por essa organização, as artes premeditadas e, no interior desses esquemas, "você é obrigado a saber". Assim, os atos oficiais são sempre compartilhados com os atores - em espaços como as HTPC -, uma vez que a expectativa é a de que ninguém os desconheça ou possa provocar embaraços aos andamentos administrativos diários.

No interior dessa perspectiva, como sugerido acima, conhecer os instrumentos oficiais, seus planos, alcances, limites e brechas, contribui para uma melhor disposição de práticas e para a mobilização mais conveniente de ações. Se os atores podem rearticular práticas, gerir decisões, provocar desvios e manipular procedimentos, o aparato regulamentar pode avançar por um refinamento cada vez mais sistemático de seus planos, de seus instrumentos oficiais, para conter a possibilidade de ajustes, para conter o incerto - uma disputa pela organização cotidiana com operações mais exigentes e identificadas como eficientes e produtivas.

Para se contrapor às manipulações, às brechas, às ilegalidades, a racionalidade legalista necessita se refazer, aparar arestas, conter as fendas, reforçar, formular e reformular aspectos e estratégias de ordenamento e previsibilidade no âmbito da realidade institucional. Dessa forma, leis e regulamentações formam um emaranhado discursivo de proibições, 
permissividades e punições no qual "a ambivalência só pode ser combatida com uma nomeação ainda mais exata" (BAUMAN, 1999, p. 11).

O conjunto de práticas da instituição escolar lida constantemente com esse discurso regulamentar. De acordo com a supervisora, "o que eles determinam lá em cima interfere drasticamente no que você faz aqui embaixo". Esse "Olimpo", essa esfera que estaria acima dos demais mortais e onde residiria o "comitê de sábios" (DELEUZE, 1992, p. 210), pode e geralmente almeja muitos objetivos, os quais seriam portadores daquele saber superior e especial - "o saber dos deuses" (FOUCAULT, 1974, p. 39). Como a entrevistada também indica em suas considerações, há uma série de atravessamentos que vão negar a conformidade exigida pelas "altas esferas": os sujeitos procuram escapar, tangenciar aspectos, ignorar leituras, manejar e recompor tarefas oficiais.

Em seu estudo sobre os mecanismos burocráticos no âmbito escolar, Lima (1995, p. 4) aponta que:

[...] a tendência é que a maioria se submeta às decisões centralizadas. Diretor, funcionário, professor, aluno e responsável acabam por fazer parte de um quadro hierárquico onde cada um deve cumprir seu dever. Não importa qual ou como. [...] A experiência enquanto aluno, professor e diretor da rede pública, mostrou-nos que a submissão e a obediência às regras estabelecidas têm sido a principal atividade na vida escolar.

Entretanto, como revelamos acima, os atores escolares não são meras peças manobráveis, não são meros indivíduos passivos e sujeitados. Há cruzamentos e interseções que ocasionam desencontros, ações rearticuladas e decisões manipuláveis em torno de uma normatividade que concebe formas de ação e de funcionamento escolar. O equívoco fundamental de algumas análises parece residir na pretensão de minimizar as possibilidades de escolhas dos sujeitos e na presunção de que dimensões oficiais onipotentes determinam as capacidades individuais de executarem ações de maneira ilimitada. Essas dinâmicas não se sucedem sem que justaposições, opções, repercussões, decisões e interações sejam acionadas, mobilizadas e articuladas, na medida em que se fazem necessárias para a concretização de esquemas e interesses em jogo na instituição escolar, como é possível constatar nos comentários da entrevistada:

[...] Há uma distância muito grande, uma distância muito grande do que está escrito e do que efetivamente acontece. [...] Pelo menos é o que eu tenho percebido muito, pela demanda de muitas legislações, por muitas ações que demandam de cada legislação, acabam muitas coisas fazendo, eu 
vou usar um termo, nas "coxas" mesmo, em cima do prazo, precisa entregar tal dia, então assim: hoje é o último dia; então a gente vai fazer, vai refazer, vai correr atrás, vai buscar a lei, não era bem isso que estava escrito... então acho que essa confusão existe muito. Que a lei pode não ser aplicada na sua essência, com certeza a gente consegue isso ver nitidamente. [...] Nenhuma legislação ela está estanque, ela sempre está vinculada com outra. [...] É muito difícil você pegar do jeito que está escrito ali e aplicar. É muito difícil, porque você erra muito e você tem... e assim: as condições não são tão adequadas. [...] A lei que foi posta ela está constantemente sendo alterada. [...] As coisas elas não são tão claras, tanto que ultimamente a gente tem tido muitos comunicados. [...] A ação um que não foi feita devidamente vai implicar na aplicação de outras ações. Então acaba você tendo que... fazer um jeito, dar um jeito pra que a lei possa ser aplicada da melhor forma possivel, mas nunca na integridade. Eu percebo que tem muitas coisas que... lógico, tem algumas que você é obrigado a fazer, mas tem algumas que constantemente a gente faz os acordos no sentido de que... fazer as adequações à escola em si. Então a lei ela acaba sendo que... as pessoas conseguem driblá-la... pra que efetivamente aconteça e acabam fazendo, tendo em vista que assim: volta o documento, vem o documento, faz documento, refaz documento... adequa assim, adequa... [...] Então os expedientes [...] eles não podem ir contra o que está previsto em lei. Eu digo que assim: quando eu digo de arranjos eu digo assim: que eu vou tentar o máximo que puder. Por exemplo, estágio probatório. Está escrito lá: se o professor ' $x$ ' não alcançar tantos limites, que é o 136 se não me falha a memória, 135, 136 pontos, que ele vai ter que ser exonerado. Então o que eu digo assim: que as escolas vão cuidar muito pra que isso não chegue nesse limite. Cuidar como? Talvez fazendo alguns expedientes pra que não chegue nesse caso. Daí eu digo que isso é um burlar lei. [...] A lei está pra ser cumprida, mas enquanto agente manipulador dessa lei aqui embaixo, eu posso usar de artifícios, e eu uso de todos os possiveis, pra que eu atenda conforme os meus interesses. E na educação isso eu percebo de uma forma muito clara. [...] A lei é a mesma; as medidas da aplicação são diferentes. Então eu acho que tem sim, tem muito claro isso. Às vezes eu sou obrigada, como supervisora, a dar a mesma orientação. Às vezes eu sou obrigada a dizer assim: 'olha, mas a lei diz a mesma coisa'. E já passei por isso. [...] Não que a lei seja alterada na essência - a lei permanece a mesma, mas as articulações de como eu manipulo essa lei, eu acho que sim, tem 
interferências. Por isso dos expedientes - depende como você quer fazer o expediente e a quem você quer, infelizmente, não agradar, mas infelizmente cumprir. Porque pra alguns a lei é dura, pra outros ela é amena, sendo o mesmo artigo.

A supervisora demonstra que há uma horizontalidade de mecanismos e decisões que atuam no interior da legislação e a despeito de suas regras. Uma vez que os expedientes "não podem ir contra o que está previsto em lei” e considerando o vão exposto entre as pretensões regulamentares e as práticas, os atores manipulam os procedimentos atrelados àquela legislação, o que implica em zelar para que determinados efeitos de sua aplicação sejam desviados de cursos indesejáveis. É a partir das regras e de seus mecanismos que os sujeitos irão utilizar "todos os artifícios possíveis" para favorecer determinado interesse e prejudicar a aplicação de ações que impliquem em resultados negativos, deletérios e desfavoráveis, de acordo com as perspectivas em jogo.

As estratégias acionadas respondem, efetivamente, aos resultados a serem alcançados. Na perspectiva da entrevistada, são ressaltadas as brechas, as fendas, as artimanhas colocadas em prática pelos atores que lidam com regras e procedimentos legais, explorando ações ajustáveis. Acordos, adequações, arranjos, cuidados, implantar jeitos, lançar artifícios, articulações, manipulações e burlar - esquemas acionáveis de acordo com os interesses e de acordo com os alvos: a quem é necessário ativar esses esquemas, amenizando o cumprimento, a penalidade, as consequências, ou a quem é necessário convocar a dureza e impessoalidade da fria e calculada lei, tornando sua execução implacável.

"Para meus amigos, tudo; para meus inimigos, a lei". Com o objetivo de ilustrar sua discussão sobre as "falhas na aplicação da lei”, O’Donnell (2004, p. 40) cita a frase sintomática que foi proferida, segundo ele, pelo ex-presidente Getúlio Vargas. A despeito do que poderia parecer uma perversão do direito e da legalidade, a frase e antiga fórmula para o uso da lei traduz o jogo manipulável e articulável sugerido pela supervisora de ensino. Em lugar de indicar falhas, a velha máxima simboliza os ajustes revelados numa prática cotidiana entremeada por mecanismos legais e possibilidades de decisões acordadas - um contexto no qual a regulação e a normalização de tarefas terminam acompanhando, em certa medida, não o que a diretiva oficial estabelece, mas aquilo que a experiência e o hábito aconselham, aquilo que convém fazer.

Então tem várias ações que, enquanto supervisor, que não estão prescritas em leis, eu diria que... é de assessorar, é de acompanhar, direcionar... Porque na legislação está escrito lá: as atribuições do supervisor. Mas 
acaba você extrapolando esses verbos, essas ações. Então assessorar é estar junto mesmo, assumir junto, até coordenar... E muitas vezes o que a gente vê nos nossos diretores, é uma situação que eu sinto, é como se eles precisassem de alguém dizer assim: 'faça, eu estou junto de você'. Então, por exemplo, vai desde [falta] justificada pros professores, desde uma ação... a suspensão de aulas... então tem muitas ações que eles nos chamam junto pra assumir. Antes as escolas faziam o erro e depois nos ligava, pra nos comunicar, pra dizer: 'olha, aconteceu tal fato, nós tomamos tal decisão $e$ aí aconteceu isto'. Hoje nós já temos o contrário. Então, muitas intervenções que eu faço nas escolas é por falta de conhecimento legislativo, muitas... não são poucas não, são muitas. Entendeu? Muitas e muitas e muitas. [...] A gente ainda cobre um pouco mais o diretor, porque o diretor precisa saber das leis. A gente também tem muitos diretores que negam a existência da lei... em prol... busca só a lei... Têm alguns que até brigam comigo - eu falo: 'o que vocês querem que eu diga? Que a lei não está escrita? Eu digo. Não está escrito no artigo tal, parágrafo tal, isso que vocês querem. Eu estou dizendo pra vocês...' Então eu levo na brincadeira mesmo, às vezes eu falo: 'é isso que vocês querem que eu diga, eu digo, mas está escrito, e vocês façam a leitura que vocês quiserem, mas que está dizendo que vocês não podem fazer tal coisa, está escrito lá'. Entendeu? Então você percebe isso. Tem uma diretora que ela briga comigo. Fala: 'mas eu só liguei pra você, só estou falando oi com você... eu sei que você vai me dizer não, eu já sei que você vai me dizer não'. Então você vai ouvir um não; a lei não te permite fazer tal e tal coisa. 'Mas...' Mas não; a lei não... Agora se você quiser fazer e não me comunicar, é uma outra história, mas a lei diz que não.

O contato diário com diretivas, regularizações, atos administrativos, decisões funcionais e questões práticas enredam a função de supervisão na trama de legalidades e ilegalidades. Em seu âmbito está compreendida a destreza para lidar com os limites fronteiriços entre o permitido e o vedado, em relação aos quais é possível transitar e considerar o legal e o ilegal para oferecer um respaldo seguro. Assumindo uma forma em que “eu estou junto de você", o respaldo é apontado pela supervisora como uma necessidade, a série de consultas indispensáveis para evitar que um erro seja cometido. Antes de assumir uma decisão, é preciso ter um apoio, ter extremo cuidado em estar constantemente respaldado - mesmo que para isso seja necessário fazer ajustes, composições, manobras e articulações. 
Concomitantemente, os comentários evidenciam aquela possibilidade de executar decisões à margem ou à revelia da legislação, desde que isso não seja dado a conhecer: "se você quiser fazer e não me comunicar, é uma outra história". Há aqui, de fato, um grau em que procedimentos e aspectos tentam ser ajustados, manipulados: num momento se conecta com a legalidade, no outro a extrapola e a ignora. Isso deixa entrever um entrechoque de perspectivas, cada qual procurando estabelecer primazia sobre a outra. Tais decisões não seguem escolhas simples. Ao contrário, há um emaranhado de considerações, há gerências cotidianas, há manipulações, elementos dispostos, ações estratégicas e procedimentos mobilizados nos vãos abertos pelas pretensões regulamentares. Acionar essas atitudes pede deliberações e ponderações, indicando que "alguma coisa da [...] intenção pessoal escapa ao espaço do poder" (DERRIDA, 2010, p. 114). Como é ressaltado na entrevista, estar bem informado e situado é fundamental nesse jogo diário.

Nós recebemos [a regulamentação] via e-mail ou pela consulta ao Diário Oficial mesmo. [...] A gente tem recebido muitas legislações via e-mail ou no próprio Diário Oficial. [...] Têm alguns comunicados via Diretoria que ainda não chegam pro grupo de supervisores, que vai direto pras escolas e que a gente ainda reclama. Mas antigamente isso era muito mais difícil. Então muitas vezes a escola não tinha informação, muitas vezes as informações eram truncadas, muitas vezes você... venciam os prazos. Então o nosso cuidado era esse. A leitura do Diário Oficial, que ainda continua, a gente acaba... O único recurso que a gente... um bom supervisor eu acho que deveria ser, diariamente, o primeiro bom dia dele seria com o Diário Oficial, embora eu não tenha essa prática, eu não tenho de... ler todos os dias ou... eu não tenho mesmo; dizer que eu tenho é mentira. Então é uma coisa que talvez eu precise até desenvolver um pouco mais isso. [...] Então acho que o primeiro momento, como a legislação chega, ela tinha que chegar desta forma que está chegando agora, bem rápida, bem direta, porque ela é viva, é uma lei viva. Então você tem que tê-la, ler, analisar, pra aplicar, se não você não consegue... você é cobrado sem saber... 'Ué, saiu? Publicado onde? Quando? Como?' Então esse caminho eu acho que nós temos feito... esse caminho de chegar as legislações nas escolas eu sinto que está bem mais rápido. [...] Quando nós temos reunião e quando assim sai muita legislação no sábado e que são assuntos pertinentes, na segunda-feira quando tem reunião ela [a Dirigente Regional de Ensino] dá pra gente uma cópia também e a gente repassa pras escolas. [...] Mas assim: é uma leitura 
breve também. Saiu a legislação, a gente lê, não se discute muito, não se faz uma ênfase muito... [...] A gente tem na educação... eu sinto que a gente interpreta muito, parece que as leis não são tão claras como deveriam ser. Eu sinto que a gente tem várias interpretações aí no meio de cada artigo, de cada inciso, de cada parágrafo. [...] Eu acho que... [o efeito do conjunto de regulamentações] é um efeito assim... devastador mesmo. Acho que nós vivemos sob essa norma constantemente, a gente está sujeito a olhar e assim, muitas vezes, como eu já te disse, não querer aplicar e você é obrigado a aplicar. Então muitas vezes as legislações elas vêem, vêem de uma forma não discutida... Então, de repente, o processo já está acontecendo e aqui embaixo a gente não está sabendo disso. [...] Professor OFA [Ocupante de Função-Atividade, não titular de cargo] mesmo, os efeitos são assim... eu olho pros professores, eu sinto pena mesmo do efeito que essas leis causaram na vida deles. [...] Os efeitos eles são devastadores mesmo. É coisa de louco mesmo. [...] Se você pegar a atribuição, todas as legislações que saíram de atribuição e pegar um professor OFA, todo esse processo é devastador. Não sei se a palavra seria essa, mas é a que me veio à cabeça... Depende da lei... acaba com a vida de alguém. [...] Como a legislação estadual ela dá... abre brechas pra ' $n$ ' questões... você tem vários mandados de segurança aí. [...] E assim... acho que é uma rejeição mesmo [...] A pessoa num... não é aquela coisa que a pessoa quer, gosta, tem prazer. Ninguém tem prazer de ler uma lei, sabe? Eu acho que na educação isso parece que ficou muito assim... realmente muito longe de mim. 'A lei não afeta a minha vida'. Eu acho que ultimamente as leis têm chegado, as educacionais, têm chegado e afetado diretamente. [...] Os efeitos aí são... efeitos muito grandiosos, e o cotidiano está ali vivendo tudo isso, o tempo inteiro. Se está vivendo o tempo inteiro tudo isso, chega uma hora que você tem que reagir. Então eu lhe digo que a escola precisa reagir, a escola precisaria pegar tudo isso, pelo menos... ou partes delas e ir esmiuçando. A lei diz que, a gente está fazendo o quê e estamos tendo que resultados?

A leitura do Diário Oficial e o uso do correio eletrônico formam os instrumentos por meio dos quais os atores se informam sobre os aspectos de seu trabalho, consultando, lendo e conhecendo as regulamentações e diretivas sancionadas pelo poder público. O comentário também denota que a legislação - apesar de um caráter dúbio e passível de interpretações - é o fundamento para cobrar a execução e o andamento das tarefas. Como instituidora do ordenamento institucional, seu efeito sobre a escola é classificado como "devastador". A 
regulamentação pode modificar a situação profissional de cada um, alterar categorias funcionais, reordenar a atribuição de aulas, conceber novas maneiras de contratação e abolir cargos e funções já existentes - o que altera o próprio relacionamento entre os atores, uns com os outros, com o trabalho e consigo mesmo.

Nesse sentido, as ingerências cotidianas podem, de fato, nos adoecer. Afinal, o sintoma tão disseminado do estresse não é outra coisa senão o resultado da relação com elementos e artefatos da contemporaneidade que nos fazem agir e reprogramar estratégias, à custa de um investimento individual de grande envergadura. Como sustenta Dubet (1997, p. 227), "hoje em dia, dificuldades do sistema se tornam os problemas psicológicos e pessoais dos indivíduos". Na conexão com obstáculos e empecilhos, a supervisora oferece uma visão de "desgaste", para a qual o reordenamento de aspectos com o uso de mecanismos legais acaba alterando a situação profissional, contratual, estatutária e, até mesmo, emocional nessa perspectiva, "acaba com a vida de alguém".

De toda forma, a entrevista concedida mostrou que as brechas para a atuação estão colocadas. Apesar de todo o empenho regulamentar, fendas surgem a partir de suas concepções - exploráveis, inclusive, no âmbito judicial. Ao lidar com aquilo que "você é obrigado a aplicar", a supervisora apresenta aos demais atores as operações instituídas e o jogo de apropriações e contornos possíveis. Naquele contato diário, os sujeitos resistem, procuram desvios, não aceitam, não concordam, se opõem, evitam o desgaste de si mesmos, não querem fazer ou seguir aquele caminho, apontando para uma aproximação que não é prazerosa e para o firme propósito de afastarem a legislação de suas práticas.

Como a própria entrevistada indica, "o cotidiano está ali vivendo tudo isso, o tempo inteiro". E os atores vivem - de acordo com o ponto de vista esboçado - procurando fugir de obrigações irritantes, procurando negar os aspectos legais do trabalho desempenhado dinâmica na qual vislumbra uma necessidade da escola "reagir", de mudar a si mesma, de considerar as diretrizes estabelecidas, o que os atores estão fazendo e quais os resultados alcançados.

Ainda que, na visão da supervisora entrevistada, essas considerações e cálculos estejam colocados como um planejamento, como algo que precisa ser desenvolvido, o exame da vivência cotidiana na escola e da esfera de ação exposta nos comentários revela sujeitos que avançam e atuam nas sendas abertas pela legislação, o que não significa um cumprimento em termos rígidos e precisos, mas um cumprimento ponderado e ajustado de forma segura aspectos situados a partir dos limites colocados pelo ordenamento legal. 
O cotidiano, as reuniões e os encontros efetivados na instituição escolar revelam mais: interações que reconfiguram a forma de lidar com estatutos e regras, apropriações que, mesmo levando em consideração os limites legais, inauguram ações e decisões sui generis, capazes de contribuir para a identidade característica da escola. Além disso, revelam uma necessidade de "objetar à atividade do poder público seus abusos, seus excessos, suas inutilidades" (FOUCAULT, 2008b, p. 338).

Dessa forma, o exercício das maneiras por meio das quais os sujeitos estabelecem relações com os regulamentos é composto por práticas entremeadas por orientações da experiência, da conveniência, e por orientações das regras, da legislação. Essas orientações não permanecem isoladas; ao contrário, entre elas há articulações, composições, justaposições, conflitos, embates, disputas por prerrogativas - dinamismos emaranhados no âmbito escolar. Trata-se de formas revestidas não simplesmente pela retração, pela oposição, pelo afastamento umas das outras, mas de conjuntos elaborados e reelaborados mutuamente, constituindo os caminhos da prática de sujeitos por atividades e tarefas escolares - aspectos que incidem sobre o exercício possível, aceitável, negociável, necessário, inevitável e articulável na função pública, um cenário de relações e de coexistência entre esses elementos. 


\section{CAPÍTULO 3 \\ BUROCRACIA, ESTADO E ESCOLA: REFLEXÕES}

[...] as ambições normativas, planificadoras [...] podem se prestar fácil e alegremente a utilizações políticas - em qualquer época e em qualquer lugar; ambições que são, elas mesmas, políticas.

Bauman, 1999

Acabamos de investigar as situações e perspectivas encontradas nas escolas, as relações entre os aspectos legais e suas conexões e desconexões com o cotidiano, os acontecimentos, as práticas acionadas, as maneiras de se relacionar com a legislação, as relações, tensões e mediações operadas entre as posições assumidas e a racionalidade formallegal, entre o legal e o ilegal. Resta-nos apresentar agora uma discussão em torno das características organizacionais implicadas numa instituição pública, a tonalidade e o sentido ideacional conferido a um feixe de injunções direcionado à atuação funcional e à noção do dever profissional, atrelado aos efeitos da administração constante. Nesta tarefa, pretendemos abordar, de maneira mais detida, reflexões teóricas com o intuito de expandir a compreensão sobre os desdobramentos das práticas em meio à racionalidade instrumental-legal que se encarna no âmbito burocrático - estatal, escolar e público.

Há um importante e extenso debate sobre essas questões, notadamente em relação à burocracia, ao Estado e aos sujeitos, o qual, aqui, não será completamente esgotado. O desenrolar do estudo indicou direções abertas e nos deparamos com teóricos que, a partir de uma conjuntura totalitária, passaram a refletir sobre os efeitos dos contatos e aproximações com a racionalidade gerencial, ordenativa. A discussão suscitada por tais teóricos lança outras características e indica formas adquiridas por um relacionamento extremamente específico entre indivíduos e esquemas formais, legais, burocráticos e instrumentais. A especificidade desse relacionamento aparecerá apenas de modo obtuso, tangencial e oblíquo, tendo em vista os autênticos esquemas acionados, as posições assumidas e as práticas observadas no cenário escolar.

A primeira parte desta dissertação tratou dos instrumentos legais e estratégicos de uma racionalidade administrativa, burocrática e gerencial. Já conhecemos as operações, as dinâmicas e os dispositivos presentes no Diário Oficial. Esse conhecimento poderia fornecer, 
de modo geral, os meios para pensar a organização das relações no ambiente escolar. No entanto, vislumbrar aquela dimensão legalista não traduz, de maneira perfeita e inequívoca, os desdobramentos subsequentes implicados na ação cotidiana. Ao contrário, o fazer diário está entremeado por práticas que indicam esquemas acionáveis, um jogo entre a convocação e utilização da lei e seu descarte, sua manipulação, com a presença de ajustes e acordos.

Da mesma forma que os sujeitos se colocam entre forças numa trama, vamos nos colocar agora entre discussões, noções e perspectivas teóricas, promovendo encontros, aproximações e, por vezes, distanciamentos a partir do ponto de vista em que nos encontramos, em face das atitudes acompanhadas durante a realização deste trabalho e dos sentidos atribuídos às ações e decisões observadas.

\subsection{Previsão, planejamento, ordem e gestão}

Como vimos, o Diário Oficial é o instrumento para a disseminação de regularidades e legalidades. Suas edições são portadoras não apenas do cabedal jurídico, mas também de uma visão, de um modo de organizar as funções e instituições públicas. As formas e maneiras de compor os arranjos ordenativos estão inseridas nos esquemas oficiais legitimados, além de estarem disseminadas por longos textos e exposições, nas quais as ações, os papéis e os próprios pontos de vista estatais são elaborados, discriminados, traçados e divulgados.

Publicada no Diário Oficial de 11 de julho de 2008, a Lei n ${ }^{\circ} 13.123$, de 08 de julho de 2008, instituiu “o Plano Plurianual para o quadriênio 2008/2011” no Estado de São Paulo. Esta lei estabelece programas, objetivos, metas e diretrizes para a administração pública, modos, concepções organizacionais, prioridades e uma visão estatal que esboça suas próprias funções, delimitando áreas de atuação, de exercício regular e ordenado, ressaltando seu papel, suas escolhas políticas, as características envolvidas nestas escolhas - toda uma arte de governo que orienta ações institucionais.

Tão discreto para apontar suas próprias falhas e equívocos, o plano estatal naquele texto é bem detalhado quando identifica a firme necessidade de fixar focos, objetivos e princípios administrativos. A disposição de elementos configurada pelo Estado, manuseando com destreza palavras e expressões, constitui, de fato, a defesa de um conjunto de ideias em torno da melhor organização e da crença na eficiência de suas formalidades administrativas. Nas concepções gerenciais que apresenta, o Estado "não abre mão de escolher e determinar 
quem vai trabalhar, onde vai trabalhar, com o que vai trabalhar e como vai realizar esse trabalho" (GALLO, 2002, p. 131).

De acordo com a publicação daquele "Plano" no Diário Oficial, a gestão do Estado e o papel que identifica como sendo o seu foram esboçados nos seguintes termos:

O governo do Estado [...] está determinado a promover uma gestão pública profissional, eficiente, em dia com as tecnologias mais modernas de administração [...]. Quatro temas estratégicos nortearão a gestão do Estado [...]: reforço da função Gestão de Governo, por meio da implantação de gerir por resultados e do realinhamento de estruturas organizacionais [...]; melhoria do Sistema de Planejamento [...] e ações voltadas para reduzir os obstáculos às ações [...]; melhoria da relação de governança frente à burocracia, ampliando a qualificação dos servidores para torná-los aliados em prol da maior modernização da gestão pública [...]; e inovação [...] contribuindo para o deslocamento do foco nos "meios" para o foco em "resultados". [...] Entre os movimentos de renovação do Estado e de reformulação de seu papel, destacou-se [...] o reforço de sua atuação como regulador e articulador. [...] A preparação [...] para atuação [...] é estratégica. [...] A ideia central da adoção de medidas desse tipo é a de possibilitar o fortalecimento de mecanismos [...] de eficiência no exercício da administração pública. [...] Visando a aperfeiçoar ações, coordená-las e integrá-las [...] planeja-se [...] fortalecer a gestão com foco no alcance de melhores resultados. [...] O papel do Estado como articulador [...] a fim de [...] obter melhores resultados. [...] A governança [...] interna ao Estado [...] deverá ser norteada pela gestão das pessoas e pela busca da efetividade. [...] O Sistema de Planejamento transformou-se em uma área estratégica no governo paulista [...]. Deve-se focar as pessoas que trabalham no governo do Estado. [...] A remuneração por resultados alcançados é uma consequência natural da contratualização na gestão pública e da auditoria de resultados que, em conjunto, formam um vértice coeso do plano de gestão pública do Estado. [...] Coerentemente, o governo promoverá a formação e capacitação da força de trabalho tendo em vista as prioridades do Estado. Isso implica fortalecer uma cultura gerencial, próativa, voltada para a produção de resultados, abandonando de vez a cultura burocrática. $O$ esforço em capacitação nos últimos três anos nas várias escolas de governo existentes no Estado tem sido intenso. [...] Um diagnóstico sintético da organização e operação administrativa do Estado 
de São Paulo apontaria para a existência de uma gestão por resultados no Estado ainda não totalmente satisfatória, apesar da existência de controles de insumos e processos. $O$ caminho da racionalização [...] será parte integrante da modernização da gestão pública. [...] Vários programas [...] destinam-se a [...] fortalecer a capacidade de planejamento e de gestão das organizações do Estado [...] tendo como premissa a gestão por resultados [...] apoiando a [...] agilidade do governo e dos serviços prestados. [...] Esta experiência inovadora de gestão [...] será ponto de partida para o estabelecimento de um modelo de gestão [...] focada em processos, com redução de cargos e ganhos de desempenho. ${ }^{42}$

O esquema ideacional traçado revela expectativas, estratégias, concepções e princípios para obter mais eficácia nas operações institucionais públicas. A série de prioridades, resultados a serem promovidos e aperfeiçoamentos a serem concretizados disparam procedimentos e mecanismos de ordem legal como forma de constituírem o fundamento oficial da administração. O papel, a prerrogativa do Estado como regulador legítimo procura produzir, precisamente, uma "blindagem" jurídica daqueles planos. Com a busca de uma "política de resultados", as maneiras concebidas e articuladas numa legislação normalizadora visam remover aquilo que pode ser identificado como "obstáculos práticos" - os aspectos e circunstâncias que podem comprometer a melhor execução ou a aplicação mais eficiente dos esquemas traçados para o ordenamento público.

Profissionalismo, reforço, realinhamento, melhoria, redução de obstáculos, alianças em prol da eficiência na atuação, uma visão de burocracia como empecilho aos resultados "apesar da existência de controles" -, fortalecimento, agilidade e maior desempenho - todos esses elementos e aspectos evidenciam formas gerenciais em jogo, as racionalidades em disputa pelo maior e sempre renovado rigor administrativo, as formas como o próprio Estado procura lidar com os atores, com sua burocracia, voltando-se para o insistente alcance de resultados.

A partir dessa visão procedimental, a escola pública surge e assume sua posição institucional entremeada por princípios e esquemas ordenados, disseminados como os mais eficientes para gerir acontecimentos, padronizar decisões e compor processos "normais" de funcionamento. Assim ordenada, a jurisdição oficial é fixada e ordena a instituição de acordo com regulamentos administrativos. Administrar funções e indivíduos nesse espaço público baseia-se em textos, diretrizes, orientações escritas e princípios oficiais. As funções

\footnotetext{
${ }^{42}$ Trechos extraídos do Capítulo 6 da Lei no 13.123 de 08/07/2008, publicada no Diário Oficial de 11/07/2008.
} 
subjacentes ao exercício profissional seguem suas regras específicas e a disposição do tempo, nessa perspectiva, é matéria fundamental e preocupação constante para o andamento dos trabalhos. Essa é a estrutura geral, o espectro de ambições elementares direcionadas às instituições vinculadas ao Estado.

Nesse sentido, o Estado assume uma posição de grande ator interessado, apoiando-se em instrumentos ordenados e instituições que constituem suas redes e suas correias de transmissão - conjuntos racionais e técnicos que compõem suas estratégias e táticas. A ordem no Estado ou "a ordem estabelecida em sua mais forte autoridade" (DERRIDA, 2010, p. 87), constitui uma série de tentativas incessantes e constantemente renovadas, de envios e reenvios esquemáticos, buscando aperfeiçoamento, reforço e legitimação de instrumentos. As formas de concatenar planos e objetivos oficiais procuram estabelecer o estatuto estadual na perspectiva de uma vasta segurança para a execução de ações.

Esse conjunto de práticas de governo e esquemas regulados configura o Estado. Seu papel de regulador constitui não apenas aspecto estratégico como também estratégia de ação. A esfera estatal atua por meio de intencionalidades, define tarefas, atribui procedimentos, define idealmente a organização dos trabalhos e funções. Além disso, articula visões e concepções para gerir e manter a redução do atrito, do empecilho à ação ideal, a otimização na administração, os princípios em torno do desempenho objetivo, de acordo com as regras estabelecidas.

$\mathrm{Na}$ perspectiva foucaultiana, "o Estado é uma prática. O Estado não pode ser dissociado do conjunto das práticas que fizeram efetivamente que ele se tornasse uma maneira de governar, uma maneira de agir" (FOUCAULT, 2008a, p. 369). Os esquemas que inauguram compõem modos em torno da eficiência da gestão e noções consagradas para a execução e o desempenho produtivo no âmbito das instituições públicas. A arena de ação assim concebida conclama a oficialização, a normalização e um universalismo de procedimentos que, a despeito do ininterrupto e crescente planejamento estratégico, é reinaugurada, refeita, renovada e reformulada numa mescla de tentativas e erros de organização.

Como organização política baseada na formalidade de procedimentos, nas regras legitimadas e na autoridade racional-legal, a esfera estatal empreende incessantemente uma busca pela certeza, por experiências positivas e pela solução rápida e eficiente dos problemas, assumindo por vezes uma posição na qual não hesita em "experimentar remédios e verificar seus efeitos" (FOUCAULT, 2005, p. 168). Toda essa arte de condução e de governo almeja a 
estabilidade, uma direção, uma ordem, uma orientação precisa e refinada para minimizar atos indeterminados, descontínuos e desarticulados.

De fato, as práticas estatais e as maneiras de fazer visam estabelecer uma ideia primordial: a ordem. Os padrões e princípios adotados em nome dessa noção possuem a tarefa de assegurarem o andamento eficaz das atividades. $\mathrm{O}$ ordenamento é uma pretensão para evitar "ondulações na água”, para abolir empecilhos, implantando e renovando dispositivos técnicos e mecanismos racionalizados.

Com uma maestria digna dos grandes pensadores da sociologia contemporânea, Zygmunt Bauman (1999) apresenta e discute a indelével "ordem como tarefa". De acordo com sua argumentação, a questão da ordem surge como "questão de ordem" e é promovida à "ordem do dia" na "esteira da lufada ordenadora". Para ele, "é a luta da determinação contra a ambiguidade, da precisão semântica contra a ambivalência, da transparência contra a obscuridade, da clareza contra a confusão" (BAUMAN, 1999, p. 14). Essa luta e esse conjunto de intuitos, tornados sistemáticos, são os estratagemas em favor da certeza.

A ordenação - o planejamento e execução da ordem - é essencialmente uma atividade racional [...]. Se consistente, ela implica não apenas uma estratégia pela qual a ordem pode ser introduzida, mas também uma estratégia que lhe permita manter-se daí em diante intacta e imune a todos e quaisquer "fatores de perturbação". A imaginação dos racionalizadores é tentada pela perspectiva de um Estado de perfeição última e estável, um Estado do qual terá sido eliminada a própria possibilidade de desafio à ordem estabelecida (BAUMAN, 1999, p. 47).

O ordenamento como tarefa estratégica, os esforços deliberados e concertados para concretizar projetos e ambições da engenharia estatal tornaram-se a quintessência da forma institucional ideal. Com cálculos meticulosos, as "perturbações" procuram ser eliminadas e relegadas ao plano do insensato, do desqualificado, da irracionalidade no trato com as funções públicas. O planejamento racional aparece como a aspiração necessária do pensamento político para substituir a incerteza na esfera administrativa.

Garantir a ordem ou estabelecer a ordem consiste numa compulsão contínua, compulsão esta que perpassa a apropriação, o uso e a fundamentação jurídica, a implantação e disseminação de regulamentos, diretrizes e normas. Identificando o descuido, a irresponsabilidade e a irregularidade, a gama de princípios ordenados, legais e normativos está ancorada numa elementar desconfiança das funções e atividades desempenhadas na 
instituição pública, atrelada à probabilidade de ameaça representada pelos atores em relação ao êxito das ações oficialmente planejadas.

Esboçar maneiras de atuar, de compor com as atribuições oficiais formas de gerir assuntos, no interior de uma racionalidade administrativa eficiente e produtiva, com maior desempenho e melhores resultados, tornar tais visões possíveis e factíveis, excluindo os assombros do erro, das falhas e da fragilidade - tais aspectos consolidam o cabedal de pretensões da esfera estatal.

Os governantes modernos [...] foram primeiro e antes de mais nada legisladores; eles descobriram o caos e se puseram a domá-lo e substituí-lo pela ordem. As ordens que queriam introduzir eram por definição artificiais e, como tais, tinham de se assentar em projetos do interesse das leis que requeriam apenas o endosso da razão, deslegitimando ademais toda oposição a elas (BAUMAN, 1999, p. 32-33, grifo do autor).

Os projetos oficiais e planos legislativos - na busca pela regulamentação, pela padronização, pela decisão metódica, pela disposição conveniente de meios em torno de objetivos e pelo afastamento da insegurança procedimental -, as maneiras como são concebidas a administração, seus cálculos, sua presunção por resultados, sua impessoalidade e sua aposta na técnica, carregam as condições para entrecruzar e adotar múltiplas fórmulas, esquemas e soluções variáveis.

Tecnologias e técnicas gerenciais proliferam. Em sua procura pelo "fortalecimento" e pelo "reforço" - eminentemente legal -, a objetividade estatal origina raciocínios justificáveis para perseguir, com eficiência, dedicação e vigor, suas pretensões administrativas. Aquela objetividade produz e mantém a possibilidade de instrumentalizar dinâmicas institucionais, deixando disponível uma coleção de procedimentos metódicos e trilhas acessíveis. Nesse cenário, segundo Bauman (1998, p. 138), "não há limite para a ambição [...] de melhoria da realidade".

A racionalidade administrativa e os regulamentos que a acompanham surgem como dispositivos indispensáveis, estratégias preponderantes e primordiais nas quais resultados específicos são almejados. Trata-se de um ordenamento oficial que ambiciona, anseia, manifesta a firme e decidida vontade de vislumbrar a produção de nexos, os mais reforçados possíveis, entre princípios regrados e práticas a serem levadas a efeito diariamente. Diante da necessidade de ordem mobilizada cotidianamente, as estratégias acionadas incluem, como revelado por meio do Diário Oficial, a "melhoria da relação de governança frente à burocracia, ampliando a qualificação dos servidores para torná-los aliados" - uma procura 
pela redução do atrito, do embate, "estando o Estado" - na perspectiva sustentada por Gallo (2002, p. 159) - "numa posição tática privilegiada para resolvê-lo a seu favor".

O agrupamento de regras na forma da legislação forma um universo de preceitos, encargos, tarefas e deveres essencialmente relacionados a uma responsabilidade técnica e executória. Aquilo que é identificado como importante, num sentido formal, orbita as correspondências com o melhor conhecimento tecnológico disponível e com a expectativa de que os resultados alcancem a melhor relação entre os custos e os benefícios. Nessa conjuntura, um aspecto primordial para o alcance das expectativas diz respeito à atuação dos sujeitos, as ações realizadas por eles que tornam possível o desenvolvimento das capacidades gerenciais e o alcance dos resultados almejados.

Tais capacidades e técnicas para dispor assuntos envolvem os movimentos cotidianos de atores, os pontos e elementos que compõem a trama burocrática. De fato, a execução das ações traz o lembrete de que indivíduos formam a burocracia: eles operam preceitos, arranjos, lidam com aquelas expectativas e articulam ajustes. Os atores estão inseridos naquela estrutura para produzir resultados, fundamentada no universalismo de procedimentos. $\mathrm{Na}$ relação com diretivas, com a junção de capacidades e técnicas consideradas para melhor desempenhar planos, manobrando regulamentos e rearticulando decisões, o burocrata aparece, frequentemente, como o empecilho para os resultados, como o "freio" das mudanças, como o atrito às inovações políticas - um ator que precisa ser refreado por todos os lados para não causar embaraços e não ameaçar a plena execução das políticas de governo, noção fortemente disseminada de um funcionalismo público insolente e parasitário e em relação ao qual é preciso transformá-lo em "aliado".

Para Bauman (1998, p. 190), na maquinaria burocrática “o fator decisivo é a resposta à autoridade" - mecanismo no qual as responsabilidades individuais se esconderiam por trás do sistema de autoridade, na forma de um "direcionamento pelo outro". Ao assinalar isso, o autor destaca que, ao concordar com o direito do superior em comandar, "o ator é lançado em um estado de agente" - um comportamento de "ausência de autonomia", no qual "vê a si mesmo cumprindo a vontade de outra pessoa". Nessa circunstância, "o ator está inteiramente sintonizado à situação tal como definida e monitorada pela autoridade superior”. Ele se tornaria o "agente da autoridade".

Como ressaltamos acima, esses apontamentos fazem parte de um posicionamento teórico desenvolvido a partir de uma realidade totalitária, na qual sujeitos são identificados como "agentes burocráticos" e "dentes da engrenagem". Da mesma forma, as preocupações arendtianas se disseminam sob um indivíduo sobrepujado pelo saber técnico. Concentrado em 
desempenhar tarefas, ele se concentraria na política de sua sobrevivência. O resultado seria um espaço preenchido pela necessidade, pelo comportamento previsível e repetitivo de funcionários, a rotinização na qual a pluralidade de ideias cede sua preeminência para o pensamento realizado por uma via de mão única, o enfraquecimento de posições subjetivas diante da obrigação de demonstrar "apoio global", a atitude conciliatória às ordens e à oficialidade legal.

Cada dente da engrenagem, isto é, cada pessoa, deve ser descartável sem mudar o sistema, uma pressuposição subjacente a todas as burocracias, a todo o serviço público e a todas as funções propriamente ditas. [...] Aqueles que parecem obedecer-lhe realmente o apóiam, a ele e ao seu empreendimento: sem essa "obediência", ele nada poderia fazer (ARENDT, 2004, p. 91).

$\mathrm{Na}$ discussão que se apresenta, é possível encontrar desdobramentos dessas questões ao atentarmos para uma vertente da literatura francesa do começo do século XIX. O cáustico drama histórico de Victor Hugo, Os Miseráveis, produzido no âmbito do movimento romântico, expõe e suscita a discussão de aspectos que se interpenetram, em torno do ordenamento jurídico, das normas, da execução de ordens, da função oficial e de como a lei pode passar ao largo do reino da justiça. Ambientada na França do final do século XVIII e início do século XIX, a narrativa da obra é concebida em torno da personagem-protagonista Valjean, "alguém que, desafiando a lei, põe a nu a violência da própria ordem jurídica" (DERRIDA, 2010, p. 79). Trata-se de um homem "condenado por ter partido um vidro e furtado um pão" e libertado após cumprir uma sentença de dezenove anos, "conforme a legislação vigente" - o que é classificado pelo próprio autor como um "castigo desmedido", 43 aquilo que faria sentir a gravidade da falta cometida.

A exposição dos acontecimentos subsequentes surge como a denúncia do "caráter desumano e fatídico de uma sociedade racional em seus processos de controle" (COLI, 2007, p. 211). A personagem Javert, um implacável e determinado inspetor de polícia, "agente da autoridade", é concebido como a personificação da lei: intransigente, austero, de atitude disciplinar, rudeza e frieza, que não admite exceções e não admite piedade. O desvio em relação à ação regrada, à ordem, aciona os mecanismos legitimados na forma da sanção, da penalização, para a reafirmação e o restabelecimento da "normalidade". No mesmo sentido, a interrupção das tarefas oficiais, a desatenção, a falta de empenho, os procedimentos

\footnotetext{
${ }^{43}$ Os trechos citados podem ser encontrados na Primeira Parte, Livro Segundo. V. Hugo, Victor. Os Miseráveis. São Paulo: Hemus, 1979, p. 41.
} 
incorretos, as atitudes mantidas aquém da racionalidade prevista, se tornam reprováveis, condenáveis.

Essa personagem, cuja ação é realizada unicamente a partir do que a lei lhe permite fazer, provoca a aproximação de sua própria personificação no mundo real, seu correlato e seu reflexo: Adolf Eichmann. Nas sendas abertas por perspectivas teóricas, ambos, como autênticos respeitadores das leis, jamais as descumpriram ou desviaram do regime ordenado, sempre agindo "de acordo com a regra", segundo sua "legalidade manifesta" (ARENDT, 1999, p. 316). Considerando as reflexões arendtianas, Bach (2006, p. 29) aponta para a necessidade de comportamentos afastados de uma "banalidade", de quaisquer automatismos, "para que não estejamos fadados a reproduzir a mesma ação trágica desses 'heróis', num mundo em que a capacidade para a espontaneidade humana esteja erradicada". A ação banal, trivial, sem demais ponderações, apegada exclusivamente aos princípios oficiais, ordenados e pragmáticos, é considerada pelo pensamento arendtiano, principalmente em suas consequências:

Quando falo da banalidade do mal, falo num nível estritamente factual, apontando um fenômeno que nos encarou de frente [...]. Eichmann [...] simplesmente nunca percebeu o que estava fazendo. [...] Essa distância da realidade e esse desapego podem gerar mais devastação do que todos os maus instintos juntos (ARENDT, 1999, p. 310, grifo da autora).

A partir dos aspectos ressaltados perante a "obediência a ordens superiores" ou a “execução de atos de Estado", Arendt (2004, p. 110) prefere "considerar [...] em termos do apoio global a um empreendimento comum do que em nossos termos habituais de obediência aos superiores". Em seu ponto de vista, a autora coloca a participação naquele esquema oficial específico, totalitário e entremeado por noções administrativas, eficientes, produtivas e gerenciais na chave analítica do "apoio", da sustentação a um conjunto de tarefas arraigadas a serem executadas, num fazer metódico e diário.

Entretanto, por mais aproximações que possamos fazer com a conjuntura pública, o alcance das noções e dos sintomas apontados acima é extremamente limitado - ainda que transposições entre cenários possam auxiliar a desnudar a especificidade dos panoramas abordados, sem os esgotá-los, de maneira nenhuma. Apesar das perspectivas se desconectarem em relação aos comportamentos investigados, o conteúdo argumentativo, as análises e reflexões destacadas são merecedoras de atenções, interesses teóricos, debates e 
exposições fundamentais, ao alertarem para os desdobramentos da racionalidade técnica, burocrática e instrumentalizante na sociedade contemporânea.

É preciso ressaltar que aquelas figuras citadas acima - personagens da ficção e da realidade - se parecem com espectros, aparições tênues, frágeis, levando em consideração as práticas testemunhadas por esta pesquisa, as autênticas posições assumidas pelos sujeitos no interior das instituições escolares - sujeitos estes mediados por regras, formalidades, ordenamentos, uma racionalidade administrativa, gerencial e procedimental. As ações de um Eichmann, o anulamento de si próprio, de uma ascese sobre si e sua posição intransigente e inflexível se colocam como características imponderáveis perante nossas experiências. Demonstrando completo bloqueio da capacidade de julgar e uma demissão subjetiva em suas atitudes, a figura de um Eichmann permanece isolada das práticas e posições assumidas no cotidiano escolar público.

A despeito dos regulamentos oficiais e das prerrogativas funcionais, os atores escolares demonstraram que há posicionamentos e lutas para impedir que a ação e a possibilidade de decisão, de ajustes e composições sejam subsumidas diariamente. Eles imprimem ao seu fazer suas marcas, seus planos, suas visões. As práticas num cenário legal e oficial não indicam, como alertou Arendt (1999, p. 152), uma "obediência cega" ou uma "obediência cadavérica". De maneira consistente, não há indícios para apontar um relacionamento em termos de obediência e apoio. Parece ser exato sustentar que aqueles atores permanecem entremeados por mecanismos regulamentares e instrumentos ordenados, mediados por funções administrativas, gerenciais e legais.

Em suas práticas, cada um dos sujeitos aciona, convoca, manipula e rearticula decisões a partir das situações surgidas, dos aspectos disputados. Não há "sintonia perfeita" com os desígnios e aspectos definidos pelos "superiores". As conotações carregadas de previsibilidade nas noções de "agentes da burocracia", "agentes da autoridade" e "dentes da engrenagem" terminam não encontrando toda sua potência perante as práticas cotidianas. Os "moldes férreos" que sugerem são continuamente desgastados, desencaixados, deslocados, colocando em evidência as desarticulações acarretadas em relação ao funcionamento ideal daquela "engrenagem" institucional.

Ainda com a perspectiva arendtiana, é possível sustentar que o "útil calculado" pode não resultar na tão esperada eficiência e produtividade, tornando-se uma série de mecanismos que dão voltas em seus objetivos sem nunca chegar a um termo, perpetuamente acionado para fins nunca inteiramente alcançados. 
A perplexidade do utilitarismo é que se perde na cadeia interminável de meios e fins sem jamais chegar a algum princípio que possa justificar a categoria de meios e fins, isto é, a categoria da própria utilidade. O 'para que' torna-se o conteúdo do 'em nome de quê' (ARENDT, 2008a, p. 167).

Os componentes de plausibilidade presentes nas diretivas legais e oficiais consolidam uma áurea de objetivos, propósitos e fins para o emprego adequado de técnicas, cujos efeitos práticos almejados podem não ser constatados. As ambições estatais adentram por cirandas ordenadas ininterruptas e prolongadas, caracterizadas pela abominação da desordem, superestimando a coerência dos estímulos junto aos atores. A intervenção do Estado por meio de suas expectativas, ordenamentos, regras, procedimentos e princípios gerenciais consagrados compõem um jogo político entre dimensões instituídas oficialmente, planejadas idealmente, projetadas na mais alta aspiração eficiente, e práticas, decisões, movimentos, ações reais e concretamente efetivadas - dimensões estas tensionadas, descontínuas e desencontradas, como sintetiza Wacquant (2001, p. 36):

Na medida em que os Estados são mecanismos organizacionais altamente diferenciados e imperfeitamente coordenados, eles se engajam repetidamente em políticas que ou são incoerentes ou operam com propósitos cruzados umas com as outras. Além disso, há com frequência uma lacuna considerável entre os propósitos proclamados e os objetivos reais de uma dada política, de um lado, e sua implementação e efeitos burocráticos no "mundo real", de outro.

Os efeitos que testemunhamos não apenas compõem uma lacuna e uma discordância entre os desígnios oficiais e as decisões adotadas, ajustadas e praticadas; também evidenciam as mobilizações e manobras de aspectos legais e procedimentos consagrados pelo Estado, de acordo com as intenções, os interesses em evidência, as expectativas e escolhas assumidas pelos atores no âmbito institucional público. A partir desse panorama, e ao contrário do que é sugerido por Bauman (1998, p. 139), a burocracia não está "desprovida de forças e tendências próprias"; assim, ela não permanece "incapaz de resistir [...] a ser moldada da forma que [se] quiser".

Da mesma forma, podemos identificar certa fragilidade em relação à tendência para a “desumanização dos objetos” identificada por Bauman na esfera burocrática. Para o autor, esta é "uma tendência que pode ser descoberta em todas as burocracias, por mais benignas e inócuas as tarefas nas quais estejam empenhadas no momento". Em sua acepção, ela começa no limiar em que os objetos operados pela burocracia são reduzidos a quantificações, "a 
meros números desprovidos de qualidade" (BAUMAN, 1998, p. 126-127). O que evidenciamos consubstanciam atos nos quais os atores não lidam simplesmente com quantificações; suas decisões estão povoadas pela mobilização de qualificativos, descrições subjetivas e opiniões. No momento de tomar uma decisão, não basta enquadrá-la em termos quantificáveis, calculados em termos de notas e faltas; ela é ponderada de acordo com "qualidades": trata-se do aluno "bonzinho" ou do "aluno que enche o saco o ano inteiro".

A ordem, as programações na busca da melhor solução, os esquemas e modelos mais favoráveis, a diligência oficial para o alcance da eficiência, o aumento do desempenho nas empreitadas públicas, a diminuição dos custos para produzi-las - todas essas visões procedimentais estão simultaneamente interpenetradas e colocadas no cotidiano institucional. Os atores lidam com isso, acionam noções, enquadram formalidades às decisões acordadas, rearticulam, recompõem, ajustam aspectos, inclusive descartam e convocam aqueles esquemas legais e oficiais de acordo com as escolhas em evidência e os resultados visados. $\mathrm{O}$ sistema estatal se reinventa, lança novas engenharias oficiais; esses elementos são considerados, concatenados e manipulados numa prática que sofre recomposições, é passível de alteração, de reconfiguração, num jogo de aproximação e distanciamento, tarefas e ajustes, legalidades e ilegalidades, atos executados e decisões ponderadas diariamente.

\subsection{Experiência, prática e posicionamento}

Comentários, depoimentos, atitudes e escolhas práticas no contexto escolar atestaram a existência de atravessamentos, manipulações, composições e ajustes no interior do núcleo oficial, legalista, formal e prescritivo do âmbito institucional público. Em torno desse núcleo, docentes e gestores desenvolveram artes, habilidades, maneiras de se posicionar, de encaminhar procedimentos e de lidar com decisões, considerando os resultados a serem alcançados. A partir de embates e entrechoques com noções regulamentares, de lugares e espaços a serem conquistados e mantidos, é possível notar um deslocamento de ênfase: não se trata da aplicação da lei, da legislação em si e por si mesma, mas da "estética" de sua utilização, de seu uso cotidiano, da forma e aparência atribuída aos seus mecanismos formais, da maneira como são efetivamente articulados em contato com os elementos, objetos e acontecimentos escolares.

Em seu estudo sobre "o cuidado de si”, Foucault (1985, p. 48) aponta para três vínculos distintos: 
[...] a atitude individualista, caracterizada pelo valor absoluto que se atribui ao indivíduo em sua singularidade e pelo grau de independência que lhe é atribuído em relação ao grupo ao qual ele pertence ou às instituições das quais ele depende; a valorização da vida privada [...]; e, finalmente, a intensidade das relações consigo.

$\mathrm{Na}$ investigação que conduzimos nas escolas foi possível constatar atitudes entremeadas por ponderações, vínculos que, de fato, oscilam em termos de melhor aproveitamento, de execução de tarefas, de acordos, de discursos legitimados, de compromissos, posições assumidas, decisões acordadas, de proximidade e afastamento das legalidades - atitudes que estão imbricadas na relação que cada um dos atores possui consigo mesmo, com suas visões, esquemas próprios e modos de ação, inaugurando e reinaugurando um exercício permanente para dirigir a própria prática em contato com esquemas oficiais.

A atividade de cada sujeito - enquanto conjunto de práticas - é constituída na pluralidade dos encontros corriqueiros, no emaranhado de circunstâncias, aspectos, processos, procedimentos e contatos que consubstanciam a vivência da unidade escolar. Ao considerarem suas capacidades de atuação, de manipulação e manobra, os atores tomam parte nas relações discursivas e, ao fazê-lo, ponderam os limites transponíveis, as fragilidades na articulação de ajustes, o recuo e proximidade como elementos estratégicos no relacionamento com os aparatos racional-legais. A constituição da própria subjetividade é formada no interior da trama regulamentar, oficial e formal, no âmbito precisamente das atividades executáveis, das trilhas percorridas e atalhos descobertos; é formada, enfim, em meio às escolhas acionáveis - compondo um cenário onde os sujeitos sabem os passos que convém executar e os percursos possíveis, inclusive caminhando à margem das oficialidades estabelecidas.

O cenário observado revela que os dispositivos legais, contemplados em nossos levantamentos, não se traduzem na plena execução cotidiana de seus planos e, até mesmo, são incapazes de garantir a realização dos objetivos políticos em relação aos quais foram traçados. Dessa forma, a elaboração do quadro regulamentar assume um caráter no qual quanto menos as legislações se mostram eficientes, mais elas são consideradas necessárias para a administração e o ordenamento escolar. Tais artefatos jurídicos revelam sua fragilidade ao desconsiderarem as consequências advindas da relação com os sujeitos, atrelado a uma prepotência em supor que todos serão receptivos ao ordenamento colocado, a presunção em supor que os comportamentos podem ser alterados pela via legal.

Para Foucault (1985, p. 98), “é a modalidade do ser racional e não a qualificação estatutária que fundamenta e deve determinar, em sua forma concreta, as relações entre 
governantes e governados". Mesmo diante da "força da lei" e dos regulamentos, os atores encontram espaços atuantes para uma decisão ponderada sobre os assuntos diários, institucionais e administrativos. Docentes e gestores demonstram que, em suas profissões, não se dão ao trabalho de solicitar, em todo o tempo, autorização oficial para agir, para traçar práticas e gerir procedimentos. Antes, é num jogo entre legal e ilegal, entre limites articuláveis, necessários e contestados, que o fazer se estabelece cotidianamente. Esses atores que acompanhamos não são aquilo que suas funções definem que sejam, não se resumem à execução regulamentar de suas tarefas. Há indeterminações, desvios, programações sujeitas à imprevisibilidade, deslocamentos, rupturas, composições e manipulações. O fim principal de suas tarefas, o objetivo e propósito de suas ações estão carregados de discernimento, de construção de um relacionamento consigo mesmo, com seus pontos de vista e suas expectativas. Os apontamentos foucaultianos revelam que "toda uma elaboração de si por si é necessária para essas tarefas que serão realizadas tanto melhor na medida em que não se esteja identificado de modo ostentatório com as marcas do poder" (FOUCAULT, 1985, p. 97).

$\mathrm{Na}$ discussão colocada, é possível encontrar perspectivas que sugerem o desencontro entre dimensões eminentemente normativas e as experiências práticas realizadas concretamente. Assim, a despeito das pretensões regulamentares, o liame entre essas dimensões é tênue, descontínuo, desencontrado, passível de tensão e de atrito.

A incessante criação de leis e regulamentos restritivos, envolvendo os menores atos da vida com as mais bizantinas formalidades, tem como resultado inevitável encolher progressivamente a esfera na qual os cidadãos podem mover-se livremente. Vítimas da ilusão de que multiplicando as leis a igualdade e a liberdade se vêem mais bem asseguradas, os povos aceitam a cada dia entraves mais pesados. [...] o papel dos governos se vê obrigado a crescer mais. Estes últimos devem ter forçosamente o espírito de iniciativa, de empreendimento e de comando que os particulares perderam. Devem propor tudo, dirigir tudo, proteger tudo. O Estado torna-se, então, um deus todo-poderoso. Mas a experiência ensina que o poder dessas divindades nunca foi muito duradouro nem muito forte (LE BON, 2008, p. 189, grifo nosso).

Apesar de insistir naquilo que seria a redução inexorável do papel e da atuação do indivíduo no cenário público, apesar dessa e de outras cruciais inconsistências teóricas que poderíamos lançar com fundamento nas constatações e observações já realizadas aqui, o ponto primordial da citação precedente está precisamente no caráter efêmero e frágil das disposições 
estatal-legais. Parece exato afirmar que estas últimas não conservam um caráter "muito duradouro nem muito forte" porque o Estado possui muito menos onisciência e onipotência do que se costuma supor. Em termos metafóricos, o aparelho estatal se assemelha a uma máquina que tenta escorar, por todos os lados, uma construção cujos alicerces são abalados e estremecidos diariamente - seja por situações não previstas e, nesse sentido, não regulamentadas, seja por desconsiderar a atuação de homens e mulheres capazes de agir por trilhas e caminhos cotidianos legados pela experiência escolar, ao mesmo tempo fazendo o que precisa ser feito e relegando à legislação um lugar de suporte articulável de acordo com as circunstâncias e as decisões a serem acertadas.

No jogo essencial da "finalidade" e do "sentido", não são os esforços, reforços e insistências legais de uma autoridade oficial que poderiam fornecer os indicadores para a prática e a construção das maneiras de agir, mas "uma intensificação da relação consigo pela qual o sujeito se constitui enquanto sujeito de seus atos" (FOUCAULT, 1985, p. 47). Ações são reorganizadas, decisões são manipuladas, procedimentos formais são regulados, ajustados, abandonados, repensados, convocados, executados, a partir dos assuntos, objetivos e propósitos em vista. Trata-se de um mosaico de escolhas acionáveis e decisões razoáveis.

A perspectiva acima permite sustentar que, de acordo com Foucault (1985, p. 72), “ainda se está longe de uma experiência [...] em que o comportamento deverá se submeter à forma universal da lei”. Isso não significa que os artefatos jurídicos perderam suas prerrogativas e suas formas de aperfeiçoamento contínuo - aperfeiçoamento este motivado por um embate contínuo em torno das expectativas por melhor ordenamento, administração eficiente e decisão mais apurada.

Atuando com as regras e a despeito delas, às vezes se calando, manipulando legalidades e ilegalidades, avançando diariamente na disputa por estratégias preponderantes, os atores lutam para imprimir sua subjetividade aos modelos oficiais. Nas palavras de Ewald (2000, p. 124), “a medida comum é uma realidade eminentemente política. [...] É também aquilo pelo qual nos batemos, discutimos e nos dilaceramos, aquilo que é preciso controlar se quisermos deter o poder e tornar-nos senhores da norma”.

Compor a própria prática é uma batalha em torno de prerrogativas, em torno de procedimentos, da manipulação de alguns e utilização de outros, de questionamentos diante de ordenamentos oficiais, ajustes, alterações, mudanças, resultados esperados e indesejáveis. A atuação institucional é composta por tais entrecruzamentos, efeitos estimulados pelo contato entre esquemas consagrados e prática diária. Dessa forma, reivindicações, condutas desregradas e manobras acionadas colocam interferências aos planos estatais traçados de 
maneira ordenada, aos esforços por mais prudência, eficiência, produtividade, pela busca da ordem. O território das formalidades legais é constantemente interpelado e colocado em evidência, ao mesmo tempo em que os limites que podem ser transpostos são considerados, avaliados e acionados; as individualidades estão constantemente expostas, por vezes se recusando a agir no interior das formas administrativas consolidadas, buscando atalhos na execução, desvios, maneiras de recompor decisões, liberando atos do tipo de racionalidade administrativa que se liga ao Estado, minando, assim, os "sonhos" oficiais e legislativos.

Quanto mais profundamente penetramos num âmbito emaranhado de regras, práticas, normas e experiências, mais solidamente emergem a simultaneidade desses elementos no cotidiano e o entrecruzamento das noções que os acompanham no cenário escolar. Estamos diante de um debate que envolve os fundamentos empíricos do trabalho e das funções públicas, em relação ao qual muito já foi escrito e certamente muito ainda será explorado.

Hannah Arendt (1999), Theodor Adorno (1986) e Zygmunt Bauman (1998) apontam para os efeitos da ênfase no imediatismo e no saber tecnicista, mecânico e instrumental, o que seria plenamente capaz de engendrar um esvaziamento da subjetividade. Essa racionalidade se expandiria e ocuparia o lugar do discernimento. Arendt, a quem devemos uma das mais incisivas análises sobre os desdobramentos contemporâneos da existência humana, expôs em profundidade o posicionamento das condutas em face de técnicas capazes de solapar os indivíduos. Em sua obra-testamento A Vida do Espírito, a sustentação das faculdades do pensar, do querer e do julgar forma o cerne da ação fundamentada e da defesa contra uma razão instrumentalizada. Na medida em que "pensar significa examinar e questionar" (ARENDT, 2004, p. 168), o pensamento é uma atividade na qual julgamento e discernimento estão acumpliciados de maneira decisiva.

Entre as elaborações conceituais e teóricas e a realidade pesquisada é possível notar certas proximidades e diferenças significativas. Parece justo afirmar que os espaços ocupados pela expansão de uma racionalidade instrumental e administrativa ainda são espaços contestados pelos sujeitos. As exigências incitam e despertam entendimentos, interpretações, perplexidades, noções, composições e reações díspares - efeitos e consequências surgidas de um contato ímpar com mecanismos técnicos, regulamentares e burocráticos. A organização institucional das escolas requer certa dose de incorporação de regras. No entanto, na confrontação com a complexidade da realidade, as brechas ainda são perceptíveis e é por brechas que o combate em torno da subjetividade encontra suas manifestações. Em sentido complementar, os atos que testemunhamos são reações, no plano do possível e do plausível, diante da estrutura institucional escolar. 
Nas lides cotidianas, não se trata somente de operações rotineiras e procedimentais, nas quais os dispositivos regulamentares ofereceriam os planos de ação. As situações inauguradas por essas operações são aspectos provocadores de um melhor entendimento e discernimento entre os profissionais para lidarem eficientemente com as regras e decisões em evidência, exercitando "a mais alta e talvez a mais pura atividade de que os homens são capazes - a atividade de pensar" (ARENDT, 2008a, p. 13). Concebidos e formulados, os esquemas oficiais se desgastam e são refeitos, acionando e renovando ponderações, avaliações e reflexões em torno das maneiras mais eficientes de executar as tarefas, de acordo com as práticas e posições assumidas. O fundamento do fazer está colocado, então, no encontro diário com as regulamentações institucionais, nas maneiras específicas dos sujeitos de lidar com elas e a despeito delas.

Pode-se afirmar que os escritos de Arendt clamam por uma capacidade para julgar e pela consideração da pluralidade - noções caras e entrelaçadas em escritos dialógicos: a própria condição humana como potencial, numa perspectiva na qual o que cada agente está fazendo não tem como finalidade "gerar resultados, e sim iluminar a existência" (ARENDT, 2008 b, p. 211). Nesse sentido, a escola surge como espaço público no qual aquilo que acontece é colocado em questão, em análise, em avaliação, em julgamento. Docentes e gestores estão avaliando e prevendo consequências, mensurando possibilidades, defendendo articulações, posições e pontos de vista. A própria defesa do pensar é a defesa do ensaiar-se perante as inércias, ensaiar-se em novos posicionamentos. Na acepção de Larrosa (1995, p. 50), "pensar sobre a educação implica construir uma determinada autoconsciência pessoal e profissional que sirva de princípio para a prática, de critério para a crítica e a transformação da prática, e de base para a autoidentificação do professor".

As manobras instaladas reafirmam articulações e ligações com processos e procedimentos próprios da esfera pública e, ao mesmo tempo, rompimentos, recomposições e ajustes perante esquemas oficiais cristalizados no interior de uma concepção de ordem, de gestão, de administração, de eficácia, de redução de embaraços. Os afazeres, as condutas, os pensamentos, as propostas de intervenção e manipulação, as vontades e as escolhas realizadas pelos atores estão numa relação em que assumem a possibilidade de enveredarem por outras maneiras de fazer, de atuar e decidir, de inaugurarem aspectos e consequências não previstas pelas formalidades legais e regulamentações oficiais - compondo um distanciamento de determinadas coisas e avizinhamento de outras, alterando o consequente relacionamento com a execução de tarefas e transformando os próprios paradigmas oficiais, os quais são 
reestruturados, reelaborados e constantemente disseminados na expectativa de que possam garantir o ordenamento ambicionado.

Entregues a si mesmos, os negócios humanos só podem seguir a lei da mortalidade, que é a única lei segura de uma vida limitada entre o nascimento e a morte. O que interfere com essa lei é a faculdade de agir, uma vez que interrompe o curso inexorável e automático da vida cotidiana [...]. Fluindo na direção da morte, a vida do homem arrastaria consigo, inevitavelmente, todas as coisas humanas para a ruína e a destruição, se não fosse a faculdade humana de interrompê-las e iniciar algo novo, faculdade inerente à ação como perene advertência de que os homens, embora devam morrer, não nascem para morrer, mas para começar (ARENDT, 2008a, p. 258).

Num desdobramento concreto suscitado pela perspectiva arendtiana, podemos apontar que a vida dos atores não se resume à execução administrada de tarefas; ao contrário, ela está povoada de ideias, de desvios, de possibilidades arquitetadas, de acordos plausíveis, de escolhas e decisões que irrompem em meio a um edifício de regras planejadas, a partir de instruções, a despeito das diretivas, desarticuladas e combinadas com os suportes legais aspectos que se interpenetram incessantemente.

Tal conjunto de práticas e posições assumidas constitui o produto do pensamento e do juízo, enfrentando esquemas, estruturas oficiais e ambições estatais, procurando e tentando conciliar noções, planos e resultados com aquilo que precisa e pode ser feito, num perpétuo jogo onde os limites entre ilegalidades e legalidades estão colocados, onde os cálculos entre a ação necessária e aquela passível de ser levada a efeito de acordo com a decisão dos sujeitos, agindo por si mesmos e segundo suas próprias escolhas, são realizados com o intuito de evitar consequências deletérias, para si mesmos e para suas decisões.

No âmbito desta argumentação, a perspectiva arendtiana ressalta a configuração da conduta humana, na qual a ação carrega a possibilidade de inaugurar, de compor e recompor práticas e experiências, assumidas na afirmação da responsabilidade pelo curso das decisões cotidianas, mesmo diante das formalidades, dos esquemas políticos oficiais e legais. Assim, de acordo com Carvalho (2010, p. 849),

se há, na visão de Arendt, um vínculo entre educação e liberdade, este não se traduz na proposição de práticas pedagógicas [...] mas numa perspectiva de formação ético-política. [...] Para Arendt, os homens não nascem livres, mas nascem para a liberdade, que em sua dimensão de conquista política só pode 
ser experimentada $[. .$.$] na experiência compartilhada dos que são dotados da$ responsabilidade política pelo curso do mundo.

É nas escolas, em meio aos mecanismos regulamentares, que homens e mulheres disputam e sustentam, por suas práticas, experiências, comentários e maneiras de atuação, posicionamentos numa vivência institucional perpassada pela execução de tarefas sobre as quais são realizadas articulações, composições, deslocamentos, rupturas, ajustes, acordos e manobras em relação aos procedimentos legais. O limiar das ações permanece entremeado por elementos integrados à prática e aspectos que compõem a formação de uma existência profissional constituída por caminhos acessíveis.

Não se trata simplesmente de incontornáveis amarras legais ou de uma liberalização contínua de procedimentos regrados; trata-se de uma plausibilidade de escolhas, da manipulação de instrumentos na proporção dos objetivos em jogo, de um conjunto de práticas levadas a efeito pela vontade ativa dos sujeitos, da articulação de procedimentos legais e acordos que tangenciam essa legalidade, no âmbito de uma visão racional, pública e política que identifica os melhores meios, as ações mais produtivas e a maior eficácia técnica. Nessa compreensão, é possível notar, com Arendt (2010, p. 274), que "a necessidade da Vontade de querer não é menos forte do que a necessidade que a Razão tem de pensar; em ambos os casos, o espírito transcende suas próprias limitações”.

Assim, no âmbito de nossas observações, constatamos que os atores não são indivíduos incapazes de articular suas próprias escolhas e decisões ou seres atrelados incondicionalmente à estrutura oficial, às regras e paradigmas legais. Ao contrário, são sujeitos que, em suas particularidades, fazeres e experiências, lutam com suas estratégias, que caminham no limiar do legal e do ilegal, que transitam e jogam com essas forças; sujeitos que decidem participar e não participar, que optam por suas identidades, na sua positividade, na sua produtividade, que assumem posicionamentos e fazem suas escolhas no contexto da instituição escolar. 


\section{CONSIDERAÇÕES FINAIS}

O trabalho desenvolvido aqui procurou articular dimensões essenciais à Sociologia: por um lado, o exame de uma dimensão estrutural, ligada à racionalidade legalista; por outro, os posicionamentos e relacionamentos dos sujeitos em suas práticas cotidianas, as atitudes e as formas assumidas pelas subjetividades.

Optando por abordar a estrutura administrativa de escolas públicas estaduais, numa análise sobre a ordenação racional e deliberada do poder público e sobre sua atuação na padronização da estrutura de funcionamento das unidades de ensino, nossa hipótese inicial, submetida ao teste empírico, era a de que a ação estaria fortemente baseada nos regulamentos, visto que os atores implicados no sistema de ensino se encontram mergulhados numa estrutura que exige, a todo o momento, cumprimento de regras e sobrevaloriza a autoridade. Nesse início, já apontávamos para as possibilidades de articulações e tomadas de posição.

O exame da vivência cotidiana na escola revelou a inconsistência e inadequação dessa hipótese - uma suposição inicial conduzida, em certo sentido, por uma noção de prerrogativas regulatórias que compelem à homogeneidade e à padronização. Ao mesmo tempo, revelou as manobras e manipulações que acompanham a relação com os mecanismos legais. A análise empreendida esteve concentrada em oferecer, precisamente, uma visão de como encontramos concretizado esse relacionamento.

Organizado em dois momentos específicos, iniciamos este estudo nos dedicando à discussão do ordenamento racional público, em sua atuação padronizada por meio de regulamentos oficiais e procedimentos formais publicados no Diário Oficial do Estado de São Paulo, formando um espectro de ambições em termos de uma racionalidade gerencial e a produção de efeitos de eficiência ao organizar as questões e ações institucionais públicas. As publicações no Diário Oficial indicaram o panorama de regulamentação estatal, o estabelecimento de disposições administrativas e legais, as crenças institucionais em torno da organização escolar.

Sob nosso ponto de vista, os atos oficiais emitidos e as regulamentações sancionadas compõem as estratégias de administração e organização do Estado. Há um emaranhado de pretensões para dispor de forma eficaz e para limitar as probabilidades de erro ou de desvio. Os aspectos apresentados indicaram a composição de uma racionalidade legalista que mobiliza noções normativas para constituir uma gestão operacional na esfera pública, a qual é traduzida por procedimentos que são incessantemente antecipados, acompanhados e ordenados. Nessa compreensão, as relações elaboradas e centralizadas no Estado 
conquistaram um estatuto de práticas "governamentalizadas", disseminadas e direcionadas como potências eficientes e produtivas na trama pública, auxiliando a compor a estratégia governamental e de "governamentalização" das instituições por meio da formulação de afirmações técnicas, jurídicas, oficiais, procedimentais e "normais".

Em uma busca incessante por segurança institucional e pela gestão da incerteza, novos meios são concebidos, novas engrenagens são acopladas, novas ideias formuladas, novos fluxos de informação são inaugurados, em nome do ordenamento das práticas. Desempenhando um papel constante de regulação, o Estado dissemina os elementos necessários para organizar melhor, organizar mais eficientemente o cotidiano escolar - uma racionalidade instrumentalizada e oficialmente prescrita, princípios administrativos de facilitação das atividades, de consecução de objetivos. Os fios da "governamentalidade" se mostraram carregados e, em certa medida, compostos por materiais forjados em toda uma atividade legislativa, mecanismos concebidos não apenas como conjunto de interdições, mas que funcionam como elementos normalizadores da instituição escolar.

A investigação precedente tentou se aproximar, com essas questões, das situações, das relações cotidianas estabelecidas, dos vínculos criados com a oficialidade procedimental e das oscilações plausíveis entre legalidade e ilegalidade. No momento seguinte deste estudo, realizamos apontamentos em relação às circunstâncias, às falas, às situações encontradas nas escolas. A pesquisa empírica, empreendida por meio da observação direta das práticas escolares de docentes e gestores, evidencia um relacionamento com aspectos legais marcado por aproximações, conexões, afastamentos, desconexões. Essas aproximações e afastamentos caracterizam uma dinâmica na qual esses elementos são passíveis de manipulação, de ajuste, de acordos, de composições. Vimos atores que estão constantemente sendo transpassados pela necessidade de gerir decisões - entremeada por lutas, apropriações e tensões que se estabelecem em torno dos instrumentos administrativos.

$\mathrm{Na}$ aproximação com o cotidiano escolar, os reflexos e efeitos dos instrumentos legais se estabelecem no limiar entre práticas ajustáveis, manipuláveis, e aquelas nas quais os mecanismos oficiais são convocados de acordo com os interesses e as conveniências em cena. As formas legalmente instituídas, os esquemas e diretrizes legais são utilizados dentro de um jogo, na medida necessária para realizar as tarefas e dispor decisões: quando interessa, convoca-se a lei. Nessa trama, os atores jogam com aspectos e elementos, procuram flexibilizar ações, contornar esquemas, movendo-se sem prejuízo por caminhos legais, recuam, esmorecem, são constrangidos, retomam o esquema oficial, explorando espaços, brechas, oportunidades e possibilidades de ação, lançando essas estratégias e traçando uma 
prática para lidar com mecanismos racional-legais, seja nos encontros semanais de HTPC, seja nas decisões do Conselho de Classe.

Os atores nas escolas demonstram iniciativas que procuram passar ao largo de regras e diretivas, assumindo posições perante elas e tomando atitudes com elas, a despeito delas, a favor delas. As unidades estaduais de ensino são lugares públicos que ainda necessitam responder exigências, mas não se encontram cerceados por elas. Vimos práticas que tangenciam e escapam de diretrizes imperativas. Falas e situações emergiram e denotaram o grau em que é possível encostar e deixar de lado os grandes aparatos regulamentares diante da prática cambiável na escola, de um caminho traçado pela experiência, por um saber e um fazer. Aqueles atores compõem suas escolhas e as articulam em suas práticas, num processo que consiste precisamente em lidar com a gestão do legal e do ilegal, manipulando e oscilando entre decisões legais e escolhas acertadas, opções assumidas a despeito dos critérios formais e oficiais.

O cotidiano não é reduzido à execução da lei e, simultaneamente, não dispensa a racionalidade formal-legal. Docentes e gestores transitam em meio aos mecanismos institucionais e conseguem articular ações, posições e decisões na trama regulamentar; é um contexto de manobras em torno daqueles elementos regulamentares, de acordos, de negociações, de manipulação da ilegalidade - uma autêntica arte de explorar os meios disponíveis.

Se os atores rearticulam práticas e decisões, provocam desvios e manipulam procedimentos, o aparato regulamentar avança por um refinamento cada vez mais sistemático de seus planos, formando um conjunto de estratégias estatais de significativa preponderância, mas que não coleciona todos os troféus. Suas ambições e pretensões são desarticuladas e negadas por uma série de atravessamentos e encaminhamentos executados pelos sujeitos - a composição de atenuações, acordos, manipulações, procedimentos manobrados, técnicas ponderadas e recalculadas -, encaminhamentos que constituem suas próprias estratégias. Há, assim, estratégias do Estado e estratégias dos sujeitos, cada uma delas acionadas e colocadas em cena para lidar com aspectos institucionais cotidianos.

O lançamento de tais estratégias implica em lutas, combates que orbitam prerrogativas políticas, normativas, e a construção da própria subjetividade: por um lado, uma racionalidade constantemente aperfeiçoada e regulada por novos mecanismos oficiais, consagrando procedimentos administrativos; por outro, uma luta para afirmar a subjetividade, manipulando, deixando de lado, convocando aqueles mecanismos oficiais. Desse relacionamento, desse encontro de elementos que compõem estratégias, desse embate, surgem 
reconfigurações mútuas: reenquadramentos legais, redefinições procedimentais, reformulações das prerrogativas estatais; na experiência e no fazer habitual, composições são empregadas, justaposições são concebidas entre mecanismos consagrados e práticas, aspectos formais e legais são articulados, ponderados e ignorados de maneira concomitante emaranhados dinâmicos que revestem o âmbito escolar.

Apesar de todo o empenho das operações instituídas, estamos diante de um jogo de apropriações e contornos possíveis. As unidades de ensino, nessa perspectiva, estão povoadas pelo estabelecimento de regularidades e pelo surgimento de desvios, pelo entrecruzamento ocasionado por essas duas dimensões elementares no cenário institucional. Mesmo perante uma estrutura formal e ordenada, as instituições escolares agem, assumem posições, enfrentam disputas, traçam suas estratégias de ação, de rearticulação, transitam por procedimentos e manipulam preceitos administrativos envolvidos em seus cotidianos, ora os negligenciando, ora os transgredindo, ora os respeitando. O imprevisível, o inconcebível, o não planejado e o subitamente inesperado surgem, mesmo com todos aqueles instrumentos jurídicos apontados, disseminados e inseridos na estrutura administrativa, visando estabelecer liames seguros, diretrizes eficientes, bem assentadas e "normais" em torno de padrões e noções organizacionais.

Ao considerarmos uma noção em torno do que seriam as consequências da mera administração ou do uso da razão instrumentalizada, dos dispositivos e da racionalidade que os acompanha, foi possível constatar que não há o estabelecimento de uma rigorosa aderência aos procedimentos. O espaço escolar, no sentido administrativo, está sendo constantemente reconfigurado e práticas alternativas estão sendo concebidas, aventadas, ponderadas e exploradas. A racionalidade instrumentalizada e a legislação estão colocadas no sistema educacional público, mas os atores envolvidos não são absorvidos exclusivamente por suas prescrições, pelo cumprimento inexorável de seus paradigmas ou por uma execução de tarefas de modo pragmático como se supunha. O processo de racionalização, no entanto, com seus esquemas e sua organização prioritária das atividades por meio de estruturas burocráticas, permanece. As observações demonstraram que não há regras que não passem pelo crivo das discussões e dos comentários.

No desenrolar deste estudo, abordamos discussões e reflexões teóricas em torno das características organizacionais e administrativas; exploramos perspectivas teóricas para expandir a compreensão de aspectos e desdobramentos encontrados. Procuramos mostrar, por meio de ideias próprias e alheias, que o arcabouço regulamentar como estratégia política no âmbito escolar reverbera em atitudes e manifestações; ao mesmo tempo, as manifestações 
indicam uma relação que extrapola a mera execução de obrigações materializadas em dispositivos legais. Antes, tal relação evidencia uma luta por brechas, a afirmação da subjetividade no limiar dos estatutos. O esforço empreendido aqui buscou apontar que a legislação do ensino e as relações estabelecidas pelos atores constituem um dos suportes de contribuição para o estudo das dimensões presentes nas instituições escolares.

Diante do questionamento inspirado pela perspectiva arendtiana - "o que estamos fazendo?" -, o qual nos motivou, nos orientou, servindo de açoite e guia, foi possível vislumbrar que em meio às limitações oficiais, ao contexto de atos oficiais e discursos institucionalizados, surge um panorama no qual a interação entre indivíduos e o "peso" institucional está entremeada por possibilidades, por plausibilidades, por decisões ponderáveis. Obtivemos ainda um panorama de práticas, posições, comentários e depoimentos que nos permitiu indicar atitudes incessantes de sujeitos tarefeiros, diagnosticadores e encaminhadores em meio à articulação, à composição, ao relacionamento com mecanismos e instrumentos disponíveis - atitudes exercitadas para gerir e ponderar legalidades e ilegalidades.

Esses atores ajudaram a nos revelar que, na construção de nossas ações e experiências, estamos considerando os limites adequados para as exigências, ajustando resultados, manobrando decisões. Então, nas situações surgidas, esperadas ou inesperadas, passos são dados nas margens deixadas pela legislação, a despeito de sua malha regulamentar: a lei e as formalidades são chamadas, descartadas, manipuladas, transformadas em vivência de escolhas acionáveis, num caminho traçado por trilhas disponíveis e discerníveis, identificando o que é possível usar e o que é desejável evitar.

As características das circunstâncias testemunhadas apontam para vestígios bastante mitigados de diretivas "vindas de cima" e credoras de uma "vida administrada". Os comportamentos e posicionamentos observados não chegam a oferecer a "fórmula de ouro" capaz de garantir absoluta liberdade em meio aos procedimentos e instrumentos institucionais - carregados de uma racionalidade e visão de eficiência, produtividade e profissionalismo. No entanto, essa dinâmica não apenas representa a busca por arranjos cotidianos, a disputa e o embate entre estratégias, mas também a constituição de tensões e desarticulações em relação ao funcionamento ideal das instituições escolares. 


\section{REFERÊNCIAS BIBLIOGRÁFICAS ${ }^{44}$}

ADORNO, Theodor W. Educação após Auschwitz. In: Cohn, Gabriel (org.). Theodor W. Adorno. Coleção Grandes Cientistas Sociais. São Paulo: Ática, 1986.

Tabus acerca do magistério. In: Educação e emancipação. Rio de Janeiro: Paz e Terra, 1995.

AGAMBEN, Giorgio. Homo Sacer: o poder soberano e a vida nua. Belo Horizonte: Editora UFMG, 2010.

ARENDT, H. A Condição Humana. Rio de Janeiro: Forense Universitária, $10^{\mathrm{a}}$ edição, 2008a.

A Vida do Espírito. Rio de Janeiro: Civilização Brasileira, 2010.

Compreender: formação, exílio e totalitarismo (ensaios) 1930-54. São Paulo: Companhia das Letras; Belo Horizonte: Editora UFMG, 2008 b.

Eichmann em Jerusalém. São Paulo: Companhia das Letras, 1999.

Homens em Tempos Sombrios. São Paulo: Companhia das Letras, 1987.

Responsabilidade e julgamento. São Paulo: Companhia das Letras, 2004.

ARROYO, Miguel G. Revendo vínculos entre trabalho e educação: elementos materiais da formação humana. In: Silva, T. T. da (org.). Trabalho, educação e prática social. Porto Alegre: Artes Médicas, 1991.

BACH, Augusto. Julgar é preciso... (considerações sobre o pensamento de Hannah Arendt). Cadernos de Ética e Filosofia Política, 9, p. 17-40, fev. 2006.

BAUMAN, Zygmunt. Modernidade e Ambivalência. Rio de Janeiro: Jorge Zahar, 1999.

\footnotetext{
${ }^{44}$ De acordo com a Associação Brasileira de Normas Técnicas. NBR 6023.
} 
Modernidade e Holocausto. Rio de Janeiro: Jorge Zahar, 1998.

BEAUD, Stéphane; WEBER, Florence. Guia para a pesquisa de campo: produzir e analisar dados etnográficos. Petrópolis, RJ: Vozes, 2007.

CAÇÃO, Maria Izaura. Administração da escola pública estadual: exercício solitário ou solidário? Dissertação (Mestrado). Universidade Estadual de Campinas, Campinas, SP, 1989.

CARVALHO, José Sérgio. A liberdade educa ou a educação liberta? Uma crítica das pedagogias da autonomia à luz do pensamento de Hannah Arendt. Educação e Pesquisa, São Paulo, v. 36, n.3, p. 839-851, set./dez. 2010.

COLI, Jorge. O suspeito, o detetive e a paranoia. In: Novaes, Adauto (org.). Ensaios sobre o medo. São Paulo: Editora Senac-SP/Edições Sesc-SP, 2007.

COORDENADORIA DE ENSINO DA REGIÃO METROPOLITANA DA GRANDE SÃO PAULO. São Paulo, 2011. Disponível em: <http://cogsp.edunet.sp.gov.br/index.asp>. Acesso em: 30 ago. 2011.

DEACON, Roger; PARKER, Ben. Educação como sujeição e como recusa. In: Silva, Tomaz Tadeu da (Org.). O sujeito da educação: estudos foucaultianos. Petrópolis: Vozes, 1995.

DELEUZE, Gilles. Conversações. São Paulo: Editora 34, 1992.

DEPARTAMENTO DE RECURSOS HUMANOS. São Paulo, 2011. Disponível em: <http://drhu.edunet.sp.gov.br/a_principal/index.asp>. Acesso em: 30 ago. 2011.

DERRIDA, Jacques. Força de Lei: o fundamento místico da autoridade. São Paulo: Editora WMF Martins Fontes, 2010.

DOUGLAS, Mary. Como as Instituições Pensam. São Paulo: Edusp, 2007.

DUBET, François. Quando o sociólogo quer saber o que é ser professor. Revista Brasileira de Educação, n. 5/6, p. 222-231, maio/dez. 1997.

EWALD, François. Foucault, a Norma e o Direito. Lisboa: Vega, 2000. 
EZPELETA, J.; ROCKWELL, E. Escola e classes dependentes: uma história do cotidiano. In: Pesquisa participante. São Paulo: Cortez, 1989.

FELIX, Maria de Fátima Costa. Administração de empresa e administração escolar Administração Científica? (uma análise da proposta do Estado capitalista brasileiro para burocratização do sistema escolar). Dissertação (Mestrado). Faculdade de Educação, Universidade Estadual de Campinas, Campinas, SP, 1982.

FORTUNATO, M. P. O Desafio da Gestão Participativa na Escola Pública no Estado de São Paulo e o Desencontro do Sistema Burocratizado: 1991-1995. Dissertação (Mestrado). Faculdade de Educação, Universidade de São Paulo, São Paulo, 1998.

FOUCAULT, M. A Governamentalidade. In: Estratégia, Poder-Saber. Coleção Ditos \& Escritos, vol. IV. Rio de Janeiro: Forense Universitária, 2006a.

A Verdade e as Formas Jurídicas. Rio de Janeiro: Divisão de Intercâmbio e Edições, PUC/Rio, 1974.

Aula de 15 de março de 1978. In:

São Paulo: Martins Fontes, 2008a. Segurança, Território, População.

. Aula de 21 de março de 1979. In: Nascimento da Biopolítica. São Paulo: Martins Fontes, 2008b.

Ética, Sexualidade, Política. Coleção Ditos \& Escritos, vol. V. Rio de Janeiro: Forense Universitária, 2006b.

. História da Sexualidade I: A vontade de saber. Rio de Janeiro: Graal, 1988.

. História da Sexualidade 2: O uso dos prazeres. Rio de Janeiro: Graal, 1984.

História da Sexualidade 3: O cuidado de si. Rio de Janeiro: Graal, 1985.

. Microfísica do Poder. Rio de Janeiro: Graal, 1979.

O Sujeito e o Poder. In: Dreyfus, Hubert L.; Rabinow, Paul. Michel Foucault Uma trajetória filosófica. Para além do estruturalismo e da hermenêutica. Rio de Janeiro: Forense Universitária, 1995. 
Vigiar e Punir. Petrópolis: Vozes, 2005.

FUKUYAMA, Francis. Construção de Estados: governo e organização no século XXI. Rio de Janeiro: Rocco, 2005.

FUNDAÇÃO SISTEMA ESTADUAL DE ANÁLISE DE DADOS. São Paulo, 2011. Disponível em: <http://www.seade.gov.br>. Acessos em: 30 ago. e 27 dez. 2011.

GALLO, Sílvio. A escola pública numa perspectiva anarquista. Verve: Revista do Nu-Sol Núcleo de Sociabilidade Libertária do Programa de Estudos Pós-Graduados em Ciências Sociais da PUC-SP, São Paulo, n. 1, p. 124-164, 2002.

GOFFMAN, E. Manicômios, Prisões e Conventos. São Paulo: Perspectiva, 2005.

GÓMEZ, A. I. Perez. As funções sociais da escola: da reprodução à reconstrução crítica do conhecimento. In: Compreender e transformar o ensino. Porto Alegre: Artes Médicas, 1996.

GRACELLI, Aldemir. Burocracia: estrutura de dominação ou submissão? São Paulo: Cortez, 1986.

HUGO, Victor. Os Miseráveis. São Paulo: Hemus, 1979.

IMPRENSA OFICIAL DO ESTADO DE SÃO PAULO. São Paulo, 2011. Disponível em: <http://www.imprensaoficial.com.br>. Acesso em: 30 ago. 2011.

LARROSA, Jorge. Tecnologias do Eu e Educação. In: Silva, Tomaz Tadeu da (Org.). O sujeito da educação: estudos foucaultianos. Petrópolis: Vozes, 1995.

LATOUR, B. Jamais Fomos Modernos. São Paulo: Editora 34, 1994.

LE BON, Gustave. Psicologia das Multidões. São Paulo: Editora WMF Martins Fontes, 2008.

LIMA, Antonio Bosco de. Burocracia e participação: análise da (im) possibilidade da participação transformadora na organização burocrática escolar. Dissertação (Mestrado). Faculdade de Educação, Universidade Estadual de Campinas, Campinas, SP, 1995. 
MERTON, Robert King. Estrutura burocrática e personalidade. In: Campos, Edmundo (org.). Sociologia da burocracia. Rio de Janeiro: Zahar, 1971.

MINGUILI, Maria da Glória. A gestão da escola pública no Estado de São Paulo: da intenção à obra. Tese (Doutorado). Universidade Estadual de Campinas, Campinas, SP, 1995.

MONLEVADE, J.; SILVA, M. A. Quem manda na educação no Brasil? Brasília: Idéa, 2000 .

MOREIRA, Antonio Flávio Barbosa. A recente produção científica sobre o currículo e multiculturalismo no Brasil (1995-2000): avanços, desafios e tensões. Revista Brasileira de Educação, n. 18, p. 65-81, set./dez. 2001.

MOTTA, Fernando C. Prestes. Introdução a organização burocrática. São Paulo: Brasiliense, 1988.

NUNES, Edson. A gramática política do Brasil. Clientelismo e insulamento burocrático. Rio de Janeiro: Jorge Zahar, 1997.

O'DONNELL, Guillermo. Why the Rule of Law matters. Journal of Democracy. National Endowment for Democracy and The Johns Hopkins University Press, Baltimore, v. 15, n. 4, out. 2004. Disponível em:

<http://home.comcast.net/ lionelingram/odonnell_WhyRuleOfLawMatters.pdf >. Acesso em: 03 out. 2012.

PEREIRA, Sueli Menezes. Políticas de Estado e organização político-pedagógica da escola: entre o instituído e o instituinte. Ensaio: Avaliação e Políticas Públicas em Educação, v. 16, n. 60, jul./set. 2008.

RANCIÈRE, Jacques. Do medo ao terror. In: Novaes, Adauto (org.). Ensaios sobre o medo. São Paulo: Editora Senac-SP/Edições Sesc-SP, 2007.

. O Desentendimento - política e filosofia. São Paulo: Editora 34, 1996.

SANTIAGO, Homero. Adorno, Auschwitz e a esperança na educação. Cadernos de Ética e Filosofia Política, 6, p. 111-122, jan. 2005. 
SANTOS, B. de Sousa. Dilemas do nosso tempo: globalização, multiculturalismo e conhecimento. Educação \& Realidade, v. 26, n. 1, p. 13-32, jan./jul. 2001.

SÃO PAULO (Estado). Diário Oficial do Estado de São Paulo, Poder Executivo, Seções I e II, 2007-2008. Tiragem diária. Disponível em: <http://www.imprensaoficial.com.br>.

Secretaria da Educação. Legislação de Ensino Fundamental e Médio. Unificação de

Dispositivos Legais e Normativos relativos ao Ensino Fundamental e Médio. São Paulo, 2008.

SECRETARIA DE ESTADO DA EDUCAÇÃO DE SÃO PAULO. São Paulo, 2011. Disponível em: <http://www.educacao.sp.gov.br>. Acesso em: 30 ago. 2011.

SELL, Carlos Eduardo. Sociologia Clássica: Marx, Durkheim e Weber. Petrópolis, RJ: Vozes, 2012.

SOARES, Fabiana de Menezes. Teoria da legislação: formação e conhecimento da lei na idade tecnológica. Porto Alegre: Sergio Antonio Fabris Editor, 2004.

TRAGTENBERG, Maurício. Burocracia e Ideologia. São Paulo: Ática, 1977.

VEIGA-NETO, Alfredo. Pensar a escola como uma instituição que pelo menos garanta a manutenção das conquistas fundamentais da Modernidade. In: COSTA, Marisa Vorraber. A Escola tem futuro? Rio de Janeiro: DP\&A, 2003.

VILELA, Rita Amelia Teixeira. Críticas e possibilidades da educação e da escola na contemporaneidade: lições de Theodor Adorno para o currículo. Educação em Revista, Belo Horizonte, v. 45, p. 223-248, jun. 2007.

WACQUANT, Loïc. Os condenados da cidade: estudos sobre marginalidade avançada. Rio de Janeiro: Revan, 2001.

WEBER, Max. A ética protestante e o espírito do capitalismo. São Paulo: Pioneira, 2001.

Os três tipos puros de dominação legítima. In: Cohn, Gabriel (org.). Max Weber: Sociologia. Coleção Grandes Cientistas Sociais. São Paulo: Ática, 1979. 